\title{
4. SITE 449: WEST SIDE OF THE PARECE VELA BASIN
}

\author{
Shipboard Scientific Party ${ }^{1}$
}

\section{HOLE 449}

Date occupied: 28 February 1978

Date departed: 1 March 1978

Time on hole (hrs): 29

Position: $18^{\circ} 01.84^{\prime} \mathrm{N} ; 136^{\circ} 32.19^{\prime} \mathrm{E}$

Water depth (sea level; corrected m, echo-sounding): 4712

Water depth (rig floor; corrected m, echo-sounding): 4722

Penetration (m): 151.5

Number of cores: 18

Total length of cored section $(\mathrm{m}): 151.5$

Total core recovered $(\mathrm{m}): 93.4$

Core recovery $(\%): 62$

Oldest sediment cored:

Depth sub-bottom $(\mathrm{m}): 111.0$

Nature: Nannofossil ooze

Age: Late Oligocene (NP 25)

Measured velocity $(\mathrm{km} / \mathrm{s}): 1.55$

Basement:

Depth sub-bottom (m): 111.0

Nature: Tholeiitic basalt

Measured velocity $(\mathrm{km} / \mathrm{s}): 4.47$

Principal results: At Site 449, located on the western side of the Parece Vela basin, one hole was drilled to a depth of 151.5 meters, at which point drilling was discontinued because of poor hole conditions. The sedimentary sequence consists entirely of pelagic units deposited from the late Oligocene to the Pleistocene. From the top downward, the hole comprises: Unit 1, 40.9 meters of uppermost middle Miocene to Pleistocene dark brown to yellow-brown pelagic clay with manganese nodules on the surface; Unit 2, 6.6 meters of middle Miocene dark yellow-brown radiolarian ooze that contains volcanic glass and pumice; Unit 3,11.0 meters of middle-Miocene interbedded brown to dark brown radiolarianrich pelagic clay and yellow to brownish yellow radiolarianbearing nannofossil ooze containing pumice; Unit 4, 38.7 meters of lower to middle Miocene dark yellowish brown to very dark brown mottled, pelagic clay containing ash layers and manganese nodules; Unit 5, 13.8 meters of partly lithified, upper Oligocene to

\footnotetext{
${ }^{1}$ Loren Kroenke (Co-Chief Scientist), Hawaii Institute of Geophysics, University of Hawaii, Honolulu, Hawaii; Robert Scott (Co-Chief Scientist), Department of Geology, Texas A\&M University, College Station, Texas; Kathy Balshaw, Department of Geology, Rice University, Houston, Texas; Simon Brassell, School of Chemistry, University of Bristol, Bristol, United Kingdom; Picre Chotin, Laboratoire de Géologie Structurale, Université Pierre Marie Curie, Paris, France (now at: Departme de Góologie, Université Mohaté Pierre et Marie Curie, Paris, France (now at Deparimente med $\mathrm{V}$. Rabar, Morocco), Mary E. Heinan, Stratigraphy Laboratory, Mobil Oil Company. Dallas, Texas (now at: $\mathrm{F}$ and $\mathrm{H}$ Biostratigraphic Associates, Laramie, Wyoming): Teruaki Ishii, Ocean Research Institute, University of Tokyo, Tokyo, Japan; Barbara H. Keating, Hawaii Institute of Geophysics, University of Hawaii, Honolulu, Hawaii; Erlend Martini, Geologisch-Paläontologisches Institut, Johann-Wolfgang-Goethe-Universitat, Frankfurt am Main, Federal Republic of Germany; David P. Mattey, Department of Geology, Bedford College, University of London, London, United Kingdom (present address: Department of Geological Sciences, University of Birmingham, Birmingham, England); Kelvin Rodolfo, Department of Geological Sciences, University of Illinois, Chicago, Illinois; Renzo Sartori, Laboration Project, Scripps Institution of Oceanography, La Jolla, California; and Guram Zakariadze, Institute of Geology, Georgian Academy of Sciences, Tbilisi, U.S.S.R. (now at: V. I. Vernadsky Inst. of Geochem. and Analyt. Chem., U.S.S.R. Acad. of Sciences, Vorobyewskoe chaussee 47A, 117334 Moscow, U.S.S.R.).
}

lower Miocene yellow and brown mottled nannofossil ooze. The sedimentary section rests on tholeitic oceanic crust, the upper 23.5 meters of which is plagioclase-olivine-spinel-phyric pillow basalt and the lower 17.0 meters a plagioclase-olivine-spinel-phyric basalt flow. The normal pelagic sequence of Units 4 and 5 suggests that the basement is probably not appreciably older than the sediments, possibly of the late Oligocene.

\section{BACKGROUND AND OBJECTIVES}

Although the Parece Vela Basin is thought to have been formed by back-arc spreading following sundering of the West Mariana arc from the Palau-Kyushu arc, the timing and pattern of spreading are not known. Drilling at Site 449 was done to date the basement on the western side of the basin and thus to test for the age and symmetry of the spreading.

The Parece Vela Basin is flanked by the West Mariana Ridge on the east, the Palau-Kyushu Ridge on the west, the Shikoku Basin on the north, and the Yap arc-trench system on the south (Fig. 1). Both flanking ridges are interpreted as having been active in the midTertiary, and the Parece Vela Basin is supposed to have been formed approximately in the early Miocene (Karig, 1975). The Parece Vela Basin is roughly $5 \mathrm{~km}$ deep for the most part but is greater than $6 \mathrm{~km}$ deep in the IPOD Trough, one of a series of troughs forming the Parece Vela Rift (Mrozowski and Hayes, 1979), which approximately bisects the basin. If the age of the basin is early to middle Miocene, as proposed by Karig, then the basin is deeper than the depth versus age curves of Sclater (1972) would predict. Site 449 is located in the western part of the Parece Vela Basin (Fig. 1). In the eastern part of the basin, paleontologic dates of the oldest sediments at DSDP Sites 53 and 54 identify the age of the basement as early Miocene. Although the basalts recovered at these sites are highly altered, dredge samples collected by the International Working Group on the IGCP Project "Ophiolites" range from fresh to altered basalt and gabbros and appear to be chemically similar to mid-ocean ridge (MOR) tholeiitic basalts (Dietrich et al., 1978; Guram Zakariadze, personal communication).

The basement on the western side of the Parece Vela Basin is exceptionally rough and appears to consist of a two-part Layer 2: a low-velocity (3.1-3.7 km/s) Layer $2 \mathrm{a}$ overlying a more normal-velocity $(4.3-5.1 \mathrm{~km} / \mathrm{s})$ Layer $2 b$ (Murauchi et al., 1968). Although the sediment cover is generally thin, the cover thickens to the west, where thicknesses on the order of a few hundred meters are present on the Palau-Kyushu Ridge. Magnetic anomalies are of low amplitude in the basin; thus magnetic lineations are extremely difficult to interpret. Watts and Weissel (1975) have identified late Oligocene 


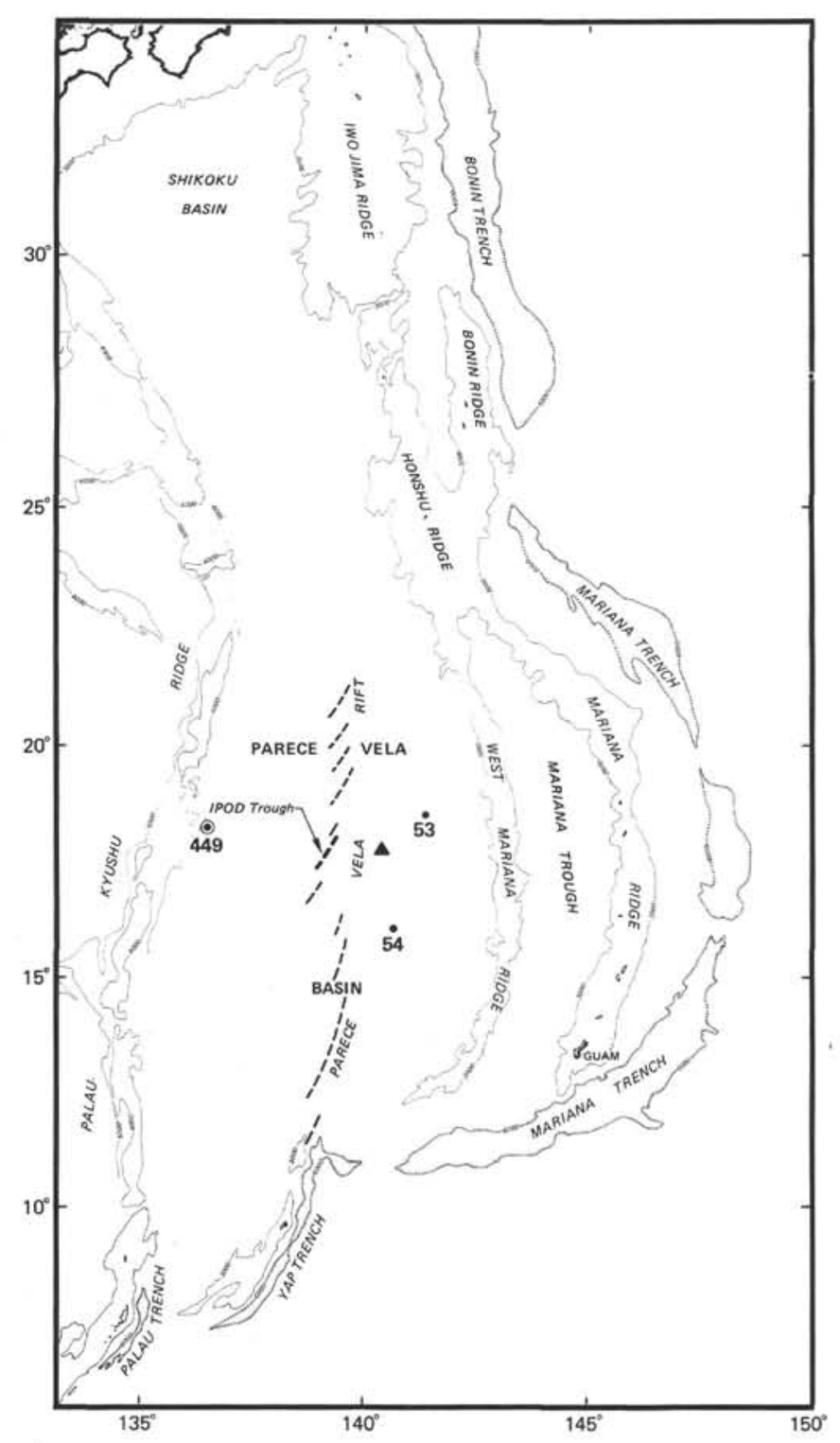

Figure 1. Location of DSDP Sites 449, 53, and 54 in the Parece Vela Basin. (The triangle marks the position of Site 1398 dredged by the Dmitry Mendeleev. Site 449 is marked by a concentric point and Sites 53 and 54 by solid dots. The Parece Vela Basin is bounded by the Palau-Kyushu Ridge on the west, the Yap Trench on the south, the West Mariana Ridge on the east, and the Shikoku Basin on the north.)

to middle Miocene anomalies ( 7 and $5 \mathrm{E}$ ) in the Shikoku Basin to the north. Shih (Leg 58, in press) suggests that the Shikoku Basin began to open 25 m.y. ago by symmetrical spreading parallel to the Iwo Jima Ridge. The age predicted by extension of these trends into the Parece Vela Basin conforms roughly with the age determined by previous DSDP drilling.

Detailed site surveys conducted by Lamont-Doherty Geological Observatory (LDGO) and Scripps Institution of Oceanography (SIO) in the vicinity of Site 449 prior to final site selection defined the rugged topography and scant sedimentary cover, which were known to characterize the western half of the Parece Vela Basin. Although water depth in the vicinity of Site 449 is approximately 4700 meters, water depth in the area was found to vary generally between 4300 and 5700 meters, with the greatest depths in excess of 5800 meters (Fig. 2). The great roughness of the area, shown in Figure 2, in addition to making the seismic-refraction work very difficult, provided the evidence for significant largescale block faulting. Sediment cover in the basin is generally thin; in fact, it commonly was found to be less than $0.1 \mathrm{~s}$ of reflection time (Fig. 3). Magnetic anomalies near the site are of low amplitude and appear to be aligned, more or less, in a north-south direction (Fig. 4). Slightly to the west of the site area, magnetic anomalies, which correlate with part of the Cenozoic anomaly series, may have been identified (Langseth and Mrozowski, this volume).

Thus the broad objective in drilling at Site 449 was to determine the mode of spreading that created the basement on the western side of the rift as well as its age. Some pertinent questions addressed included: What is the origin of the low, Layer-2a velocities? Are interarc basin basalts interbedded with significant amounts of volcaniclastic debris from the nearby interarcs? Does the age of the basement in the western Parece Vela Basin conform to the symmetrical spreading about the centrally located rift or to a nonspecific spreading mechanism, as Karig has suggested? Is the basalt chemistry of the Parece Vela Basin comparable to MOR chemistry or must new mechanisms of petrogenesis be developed to explain the origin of marginal basin basalts formed by back-arc spreading? Are Parece Vela Basin basalts similar to those studied by Hart et al. (1972) in the Mariana Trough? What type of metallogenesis occurs within the basal sediments and basaltic crust of marginal basins, and does this compare with ophiolite metallogenesis (Bonatti et al., 1979)?

The specific objective of Site 449 was to penetrate the sediments and to drill as far as possible into the lowvelocity rough basement basalts.

\section{OPERATIONS}

At 1030 Local Time (L), 27 February 1978 the Glomar Challenger departed Site 448 and, after a short reflection-profiling survey, got underway for Site 449 , which lies about 130 miles to the northeast of Site 448 and 160 miles south-southeast of Parece Vela Island. Head winds held the average speed to 8.1 knots, and the transit was made in 16 hours.

At about $0215 \mathrm{~L}$ on 28 February a presite survey was begun, and about 3.5 hours were spent profiling because of difficulty in locating a sediment pond of sufficient thickness in which to bury the bottom-hole assembly. A locality with marginal sediment thickness was finally located, and a beacon was launched. As the ship continued along its track preparatory to retrieving seismic gear, an appreciable thickening trend was observed, and a second beacon of alternate frequency was dropped about two miles from the first (Fig. 5).

After retrieving the profiling equipment and positioning the ship over the second beacon at the site on 28 February at $1500 \mathrm{~L}$, the drill string was run to the sea floor and a hole was spudded in in $\mathbf{4 7 2 7 . 5}$ meters of water. An extra bumper sub was used in the bottom- 


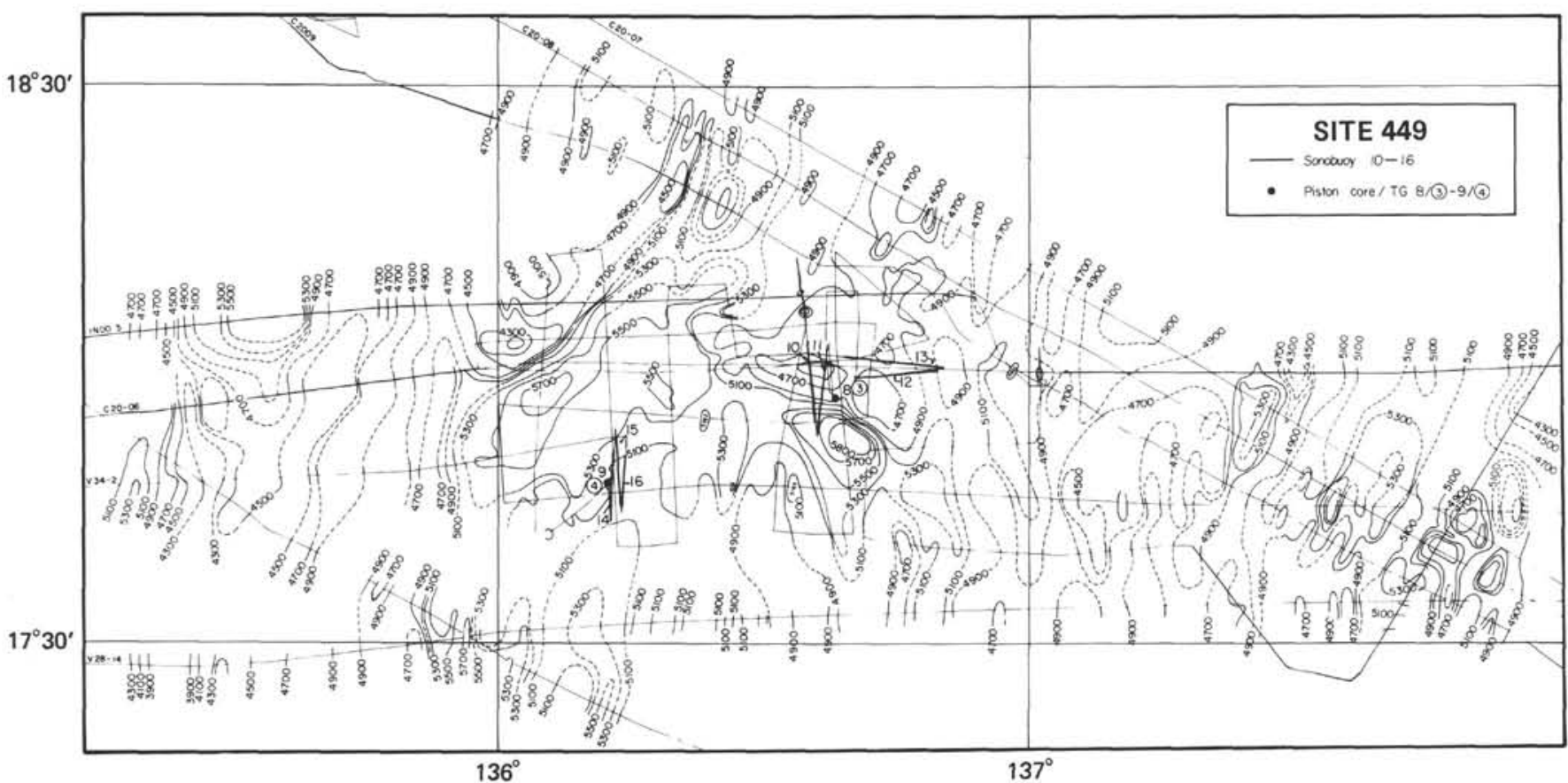

Figure 2. Bathymetry in the vicinity of Site 449 . (The contour interval is 200 meters. Solid dots with a number and a circled number indicate the core number and heat-flow station number, respectively. Dashed contours express inadequate bathymetric data. Conrad and Vema track lines are indicated; L-DGO Site Survey data-see Langseth and Mrozowski, this volume.)

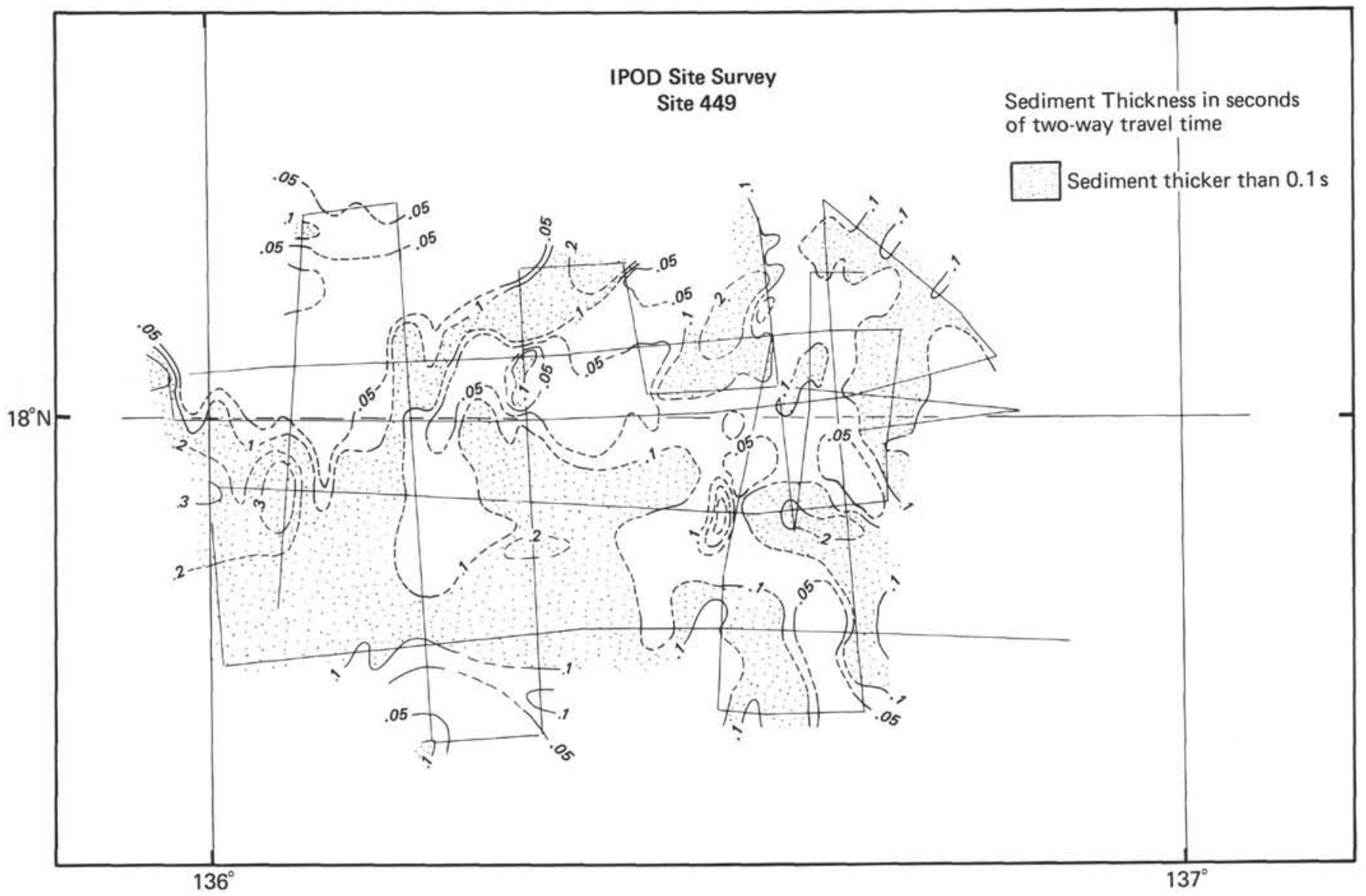

Figure 3. Sediment thickness (isochron) map of the area around Site 449 (L-DGO Site Survey data) indicated in seconds of two-way travel time. (The shaded area represents travel times greater than $0.1 \mathrm{~s}$. The track lines appearing in Fig. 2 are shown.) 


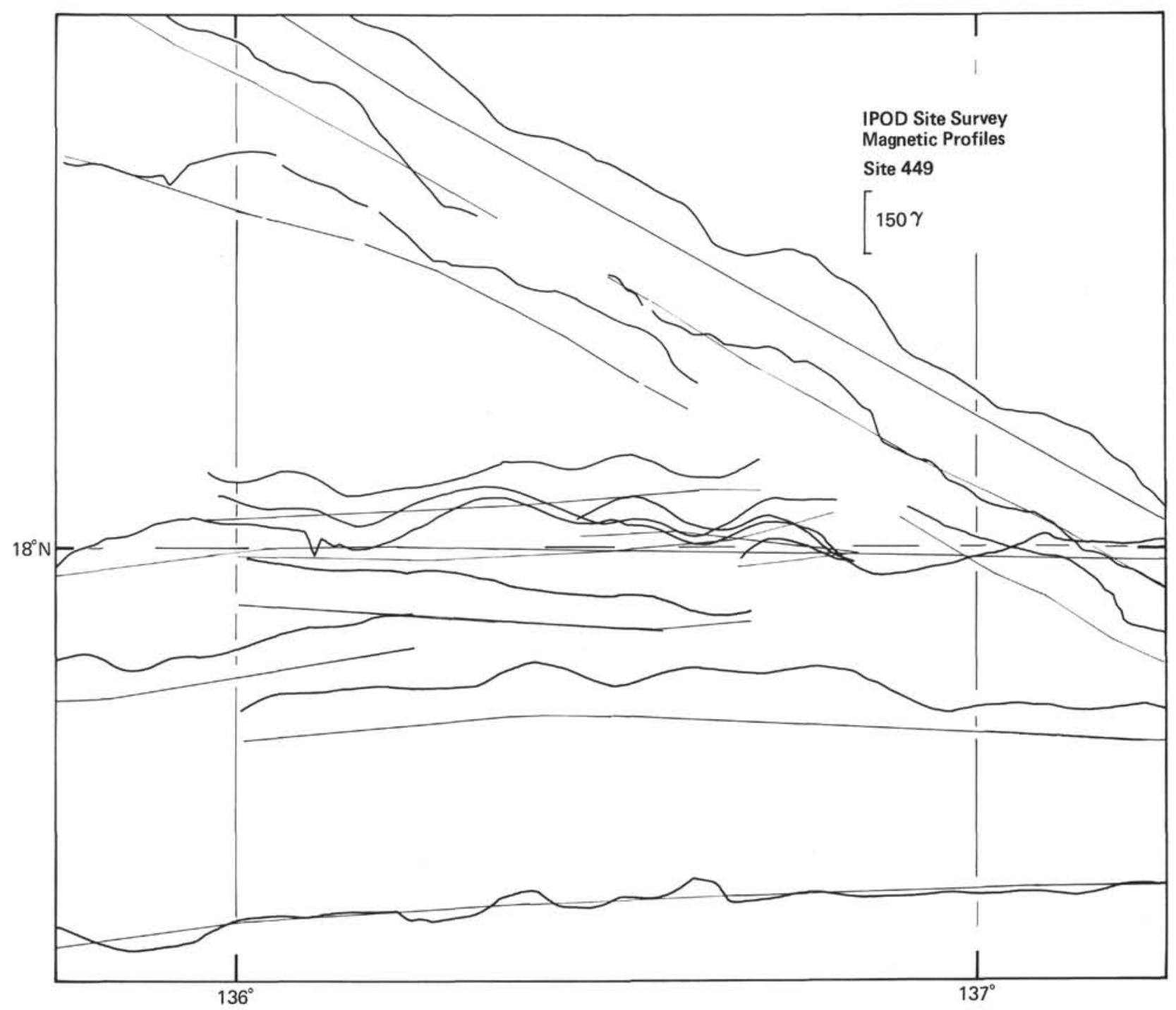

Figure 4. Magnetic-anomaly profiles and track lines in the vicinity of Site 449 (L-DGO Site Survey data). (Although the amplitudes of the anomalies are very low, distinct north-south lineations are apparent.)

hole assembly to compensate for large swells and the absence of the heave compensator. One hundred and eleven meters of soft pelagic sediments were cored before basalt was encountered (Table 1). The weathered and rubbly basalt produced low core recovery and difficult hole conditions, which deteriorated with torquing, sticking, and plugged bits. Up to 10 meters of fill began to accompany each core retrieval and pipe connection. Operations were discontinued after 40.5 meters of basalt were drilled, because of the increasing hazard to the drill string and the poor prospects for improved conditions.

The drill string was retrieved by 0415 L 1 March; after a short reflection-profile survey, the vessel was under way for Site 450 , less than 48 hours after the beacon was dropped.

\section{SEDIMENTARY LITHOLOGY}

Of the 151.5 meters of sediment and basalts drilled at Hole 449, the upper 111.0 meters consist of a sequence

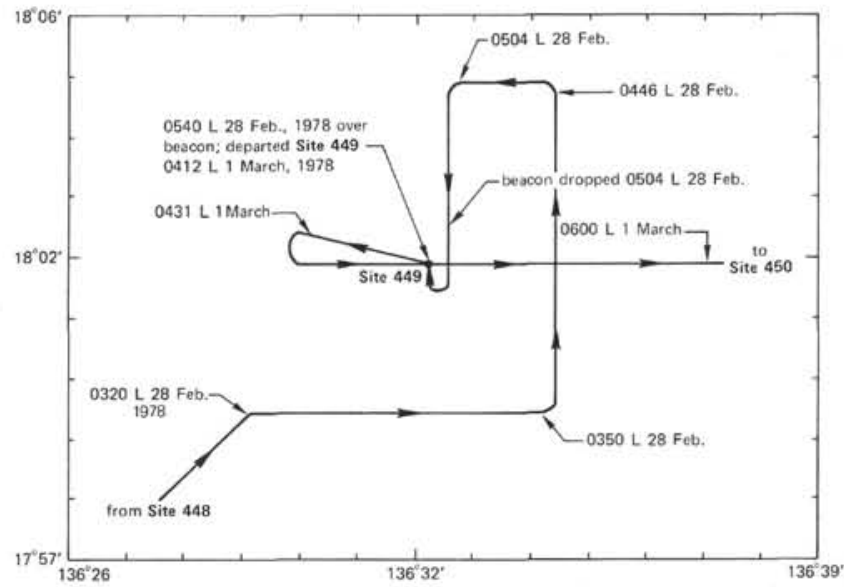

Figure 5. Track of the Glomar Challenger near Site 449 showing details of pre- and postsite surveys. (The solid dot marks the position of the beacon used for Site 449.) 
of pelagic sediments ranging in age from late Oligocene to Pleistocene in which five lithologic units can be defined (Fig. 6).

Unit 1, 40.9 meters thick (Sample 1,CC to Section $6-2$ ), is a middle Miocene to Pleistocene pelagic clay. Core 1 was barren except for three manganese nodules and very likely did not penetrate more than a few centimeters below the surface. For the most part, the pelagic clay is dark brown, with some yellowish brown intervals in Cores 3 through 6 in which iron oxides seem more abundant. Very pale brown and yellow mottling is rare and irregular. Unit 1 lithology is essentially uniform except for a thin layer of Pleistocene radiolarianrich diatomaceous ooze in Section 1 of Core 2. The unit also contains numerous small pieces of more indurated clay in Cores 3 to 6; and in Core 5 there are also lithified fragments of clay rich in manganese dendroids and more or less coated by manganese films. A single manganese nodule, $4 \mathrm{~cm}$ in length, is also present in Core 3. Several small, dark gray pumice fragments and a $10-\mathrm{cm}$ thick, yellow silt-sized ash layer are found near the bottom of the unit.

Unit 2, 6.6 meters thick (Core 6, Section 2 to the bottom of Core 6) is a middle Miocene radiolarian ooze.
Table 1. Coring summary for Hole 449.

\begin{tabular}{|c|c|c|c|c|c|c|c|}
\hline $\begin{array}{l}\text { Core } \\
\text { No. }\end{array}$ & $\begin{array}{c}\text { Date } \\
\text { (February- } \\
\text { March, } \\
\text { 1978) }\end{array}$ & $\begin{array}{c}\text { Local } \\
\text { Time } \\
\text { (L) }\end{array}$ & $\begin{array}{c}\text { Depth from } \\
\text { Drill Floor } \\
\text { (m; top-bottom) }\end{array}$ & $\begin{array}{c}\text { Depth below } \\
\text { Sea Floor } \\
\text { (m; top-bottom) }\end{array}$ & $\begin{array}{l}\text { Length } \\
\text { Cored } \\
(m)\end{array}$ & $\begin{array}{l}\text { Length } \\
\text { Recovered } \\
\text { (m) }\end{array}$ & $\begin{array}{l}\text { Recovery } \\
\text { (\%) }\end{array}$ \\
\hline 1 & February 28 & 1550 & $4727.5-4727.5$ & $0.0-0.0$ & $\mathrm{Tr}$ & $\mathrm{Tr}$ & 100 \\
\hline 2 & 28 & 1713 & $4727.5-4737.0$ & $0.0-9.5$ & 9.5 & 5.3 & 56 \\
\hline 3 & 28 & 1835 & $4737.0-4746.5$ & $9.5-19.0$ & 9.5 & 6.2 & 65 \\
\hline 4 & 28 & 1952 & $4746.5-4756.0$ & $19.0-28.5$ & 9.5 & 8.0 & 84 \\
\hline 5 & 28 & 2110 & $4756.0-4765.5$ & $28.5-38.0$ & 9.5 & 9.3 & 98 \\
\hline 6 & 28 & 2222 & $4765.5-4775.0$ & $38.0-47.5$ & 9.5 & 6.6 & $\theta 9$ \\
\hline 7 & 28 & 2347 & $4775.0-4784.5$ & $47.5-57.0$ & 9.5 & 7.7 & 81 \\
\hline 8 & March 1 & 0052 & $4784.5-4794.0$ & $57.0-66.5$ & 9.5 & 9.5 & 100 \\
\hline 9 & 1 & 0210 & $4794.0-4803.5$ & $66.5-76.0$ & 9.5 & 2.9 & 31 \\
\hline 10 & 1 & 0328 & $4803.5-4813.0$ & $76.0-85.5$ & 9.5 & 8.5 & 89 \\
\hline 11 & 1 & 0437 & $4813.0-4822.5$ & $85.5-95.0$ & 9.5 & 8.4 & 88 \\
\hline 12 & 1 & 0600 & $4822.5-4832.0$ & $95.0-104.5$ & 9.5 & 5.1 & 54 \\
\hline 13 & 1 & 0725 & $4832.0-4838.5$ & $104.5-111.0$ & 6.5 & 9.0 & $138 \mathrm{a}$ \\
\hline 14 & i & 0905 & $4838.5-4841.5$ & $111.0-114.0$ & 3.0 & 1.2 & 40 \\
\hline 15 & 1 & 1110 & $4841.5-4851.0$ & $114.0-123.5$ & 9.5 & 2.2 & 23 \\
\hline 16 & 1 & 1410 & $4851.0-4860.5$ & $123.5-133.0$ & 9.5 & 1.3 & 14 \\
\hline 17 & 1 & 1713 & $4860.5-4870.0$ & $133.0-142.5$ & 9.5 & 1.7 & 18 \\
\hline 18 & 1 & 2001 & $4870.0-4879.0$ & $142.5-151.5$ & 9.0 & 0.5 & 5 \\
\hline Total & & & & & 151.5 & 93.4 & 62 \\
\hline
\end{tabular}

Note that Core 13 recovery is $138 \%$ of the interval cored. The upper fraction of the core probably consists of material displaced from higher in the section.

The unit is dark yellowish brown and is rich in round, dark gray pumice fragments; it also contains patches, streaks, and mottles of yellow volcanic glass. Radiolarians are almost the exclusive component of the biogenous fraction, with only a few nannofossils present in the lowermost part of the unit. The clay content

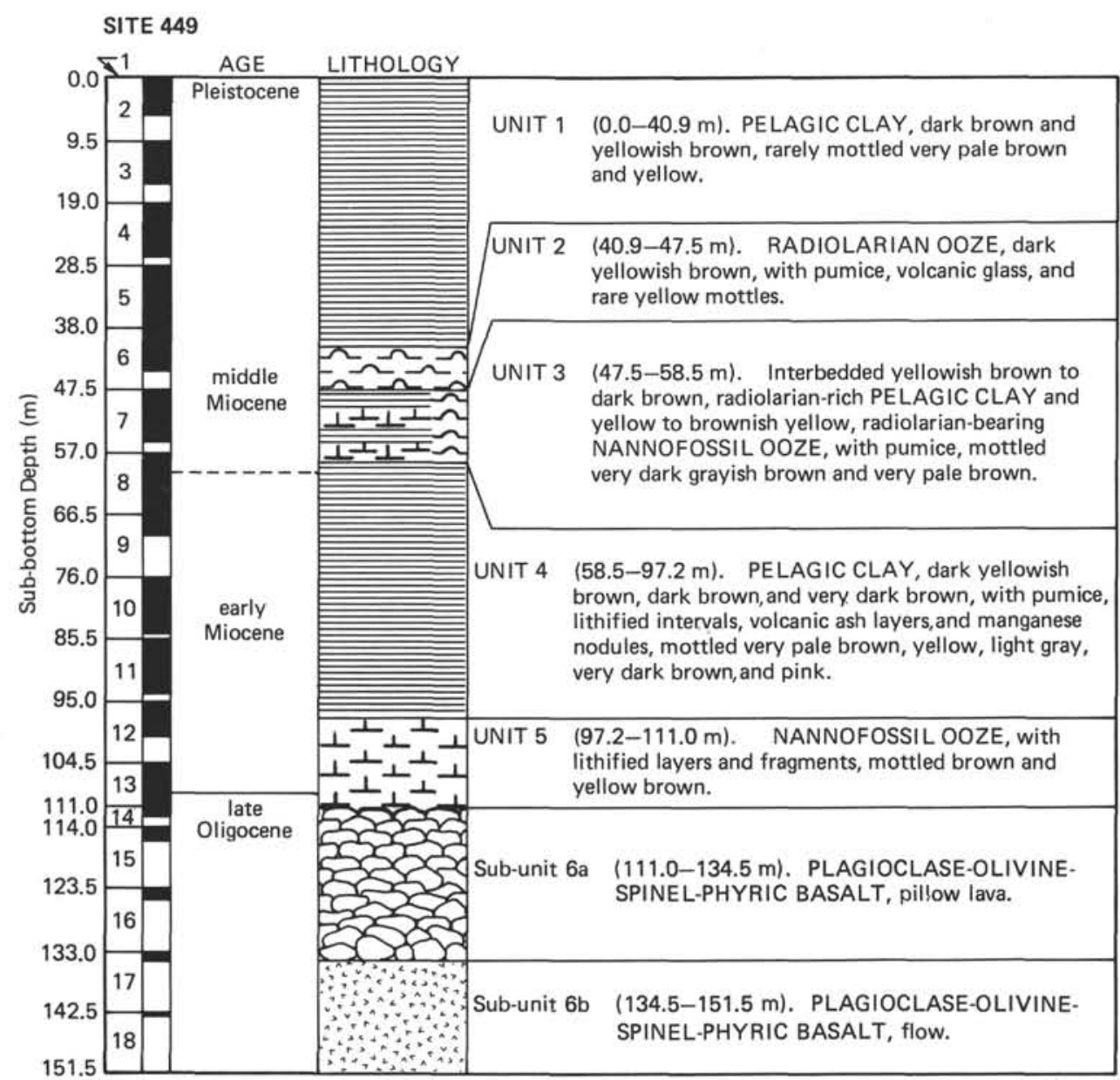

Figure 6. Lithology, age, and core recovery at Site 449. (The heavier line at the top of the pillows indicates the top of the pillow-lava sub-unit. The dashed line indicates an imprecisely determined age boundary. Core recovery is indicated by the solid symbol. Lithologic symbols are summarized in the Introduction to this volume.) 
of the unit never exceeds $25 \%$. The contact with underlying Unit 3 was not recovered and is established arbitrarily at the bottom of Core 6 .

Unit 3,11.0 meters thick, is an upper lower Miocene to middle Miocene interbedded radiolarian-rich pelagic clay and radiolarian-bearing nannofossil ooze extending down-core from the top of Core 7 through Core 8, Section 1 . It consists of complexly mottled admixtures and interbedded layers of dark yellowish brown to dark brown radiolarian-rich pelagic clay, and yellow to brownish yellow radiolarian-bearing nannofossil ooze. In Sections 1 and 2 of Core 7, the nannofossil ooze occurs as rounded fragments in a matrix of pelagic clay. Wherever preserved, the contacts between the different lithologic layers are sharp. In the nannofossil ooze, which also contains pumice fragments, very dark grayish brown and very pale brown mottles are present. In some cases this mottling is intense. The lower contact of the unit, in Section 1 of Core 8 , is gradational, with dark yellowish brown radiolarian-rich pelagic clay grading downward into normal pelagic clay without noticeable color changes.

Unit 4, 38.7 meters thick, is a lower Miocene pelagic clay that extends from the top of Core 8, Section 2 to Core 12, Section 2. Down-hole the color ranges from dark yellowish brown through dark brown to very dark brown. Common constituents are: altered pumice fragments, ash-rich clays, and thin yellow ash layers. The pumice fragments are olive-gray to black, commonly coated by manganese dendroids and films. The clays contain light gray lithified fragments and intervals enriched in volcanic ash, zeolites, and small manganese blebs. Rare manganese nodules 2 to $3 \mathrm{~cm}$ in diameter are found in Cores 8, 11, and 12. Mottling is slight, very pale brown to yellow and light gray in Cores 8 to 10 , and concentrated mainly around pumice fragments. Very dark brown and pink mottles also occur in Core 11 and correspond to local enrichments in nannofossils and zeolites. The cores from the bottom of the unit contain a complex drilling admixture. Color change occurs at the contact with Unit 5 .

Unit 5, 13.8 meters, is an upper Oligocene to lower Miocene nannofossil ooze that extends down-core from Core 12, Section 2 to the contact with the basaltic basement at the top of Core 14 . Although only a 6.0-meter interval was drilled for Core 13, the entire 9.5-meter core barrel was filled with nannofossil ooze; the upper part of Core 13 probably consists of ooze that flowed from higher in the section, and the lower part may represent the cored interval. The unit is predominantly brown. Complex drilling admixtures of yellowish brown and dark yellowish brown oozes are the chief constituents of the unit. The yellowish brown colors are characteristic of typical nannofossil ooze, whereas the dark yellowish brown colors are characteristic of micronodule-bearing nannofossil ooze. Some brown and yellow-brown mottles and a few more indurated brown pieces are also present.

The sedimentary sequence in Hole 449 consists entirely of pelagic units, probably forming an uninterrupted oceanic succession. The oldest sediment is a nannofossil ooze of the late Oligocene (Unit 5). The deposition of pelagic clay at the beginning of the Miocene (Unit 4) records the progressive deepening of the sea floor below the carbonate compensation depth (CCD). However, a departure from the usual oceanic sedimentary sequence occurs with the reappearance of nannofossil ooze intermixed with pelagic clay (Unit 3). This was followed by the radiolarian ooze (Unit 2) in the middle Miocene sediments of Hole 449.

The reappearance of these carbonate oozes can be explained in three ways: (1) They may represent turbiditic influxes of carbonates from adjacent higher regions west on the Palau-Kyushu Ridge. Evidence for this origin lies in the occurrence of sharp lithologic boundaries and pumice fragments in the calcareous oozes. (2) They may represent tectonic uplift of the seafloor above the CCD. (3) They may represent rhythmic variations in the positions of the CCD. The last two possibilities are further dealt with by Balshaw (this volume) and Sartori (this volume). After the middle Miocene, the seafloor was permanently below the CCD, initially accumulating (in Unit 2) radiolarian ooze augmented by abundant pumice and glass. The uppermost unit of normal pelagic clays is almost barren of fossils (Unit 1, middle Miocene-Pleistocene). The diminution of disseminated ash suggests cessation of volcanism.

\section{BIOSTRATIGRAPHY}

In the one hole drilled at Site 449 , there are 111.0 meters of sediment above basaltic basement. Within the sedimentary column, pelagic brown clays are dominant, and fossil occurrences are restricted to a few levels.

In the top of Core $2(0.0-9.5 \mathrm{~m})$, we found a mass occurrence of the diatom Ethmodiscus rex, along with upper Pleistocene radiolarians, rare silicoflagellates, and sponge spicules. Similar occurrences were previously noted at Sites 50, 51, 58, and 59 of Leg 6 (Fischer, Heezen, et al., 1971). Below a barren interval, middle Miocene radiolarians and calcareous nannoplankton occur in Core 6 (38.0-47.5 m) and in Core 7 (47.5-57.0 m) together with a few generally arenaceous foraminifers. Sediments encountered in Core 8 to the upper part of Core 10 are again essentially barren of fossils. Nannofossils reoccur in the lower part of Core 10 but are poorly preserved. At about the same level, rare calcareous foraminifers are present. The preservation of nannofossils and foraminifers improves downward, and, on the basis of a well-diversified tropical nannoplankton assemblage, it is possible to assign an age of early Miocene below Core $11(85.5-95 \mathrm{~m})$. The oldest sediments above the basalt are upper Oligocene, according to the nannofossils (Zone NP 25) and planktonic foraminifers (Zone P. 21?). In Core 14, below basalt, benthic foraminifers and lower Miocene nannofossils and radiolarians are found in sediments obviously caved from a higher level. (The sediment and fossil descriptions for Site 53 of Leg 6 [Fischer, Heezen, et al., 1971] are similar to that of Site 449.)

\section{Calcareous Nannoplankton}

In Hole 449, Core 1 to the upper part of Core 6 $(\sim 42.5 \mathrm{~m})$ as well as the interval between Core 8 and the upper part of Core $10(57.0-83.5 \mathrm{~m})$ are barren of cal- 
careous nannoplankton, with the exception of reworked late-Oligocene nannoplankton in Core 4.

The calcareous nannoplankton assemblage in the lower part of Core 6 is dominated by discoasters and can be placed in the middle Miocene Zone NN 6 (Discoaster exilis Zone). Samples from Core 7 contain rare Sphenolithus heteromorphus, indicating Zone NN 5 (S. heteromorphus Zone). Calcareous nannoplankton in the lower part of Core 10 and in the upper part of Core 11 are strongly etched, resulting in a selective preservation of shields of only sturdy'species and of heavily overgrown discoasters. The poor preservation of this reduced assemblage does not allow a precise age determination, but the lower Miocene Zone NN 3 ( $S$. belemnos Zone) may be represented by part of this interval. Below Core 11, assemblages are less affected by dissolution and are well diversified, especially in the lower Miocene Zone NN 1 (Triquetrorhabdulus carinatus Zone). The same applies to the upper Oligocene Zone NP 25 (S. ciperoensis Zone), which is encountered at the base of Core 13 above the basalt. Sphenolithdominated tropical assemblages are present in Zone NN 1 , including $S$. delphix and $S$. capricornutus. A similar assemblage, but also including Discoaster druggi, is found in the core-catcher sample of Core 14 below the basalt/sediment contact, representing lower Miocene material caved from above.

\section{Foraminifers}

Foraminifers are generally rare, with occurrences restricted to particular horizons and preservation only poor to fair. Cores 2 through 5 are barren. A few specimens, generally arenaceous, occur in Cores 6 to 9 . In Core 10 , a few poorly preserved calcareous specimens are present. Calcareous foraminifers increase in abundance and are better preserved down-hole from Core 10 to Core 13 (which is just above the basalt). The benthic assemblages from Cores 10 through 13 suggest a lower bathyal to abyssal depositional environment. A similar assemblage, probably caved from above, is found in Sample 14,CC (below the basalt/sediment contact). Core 13, Section 6 contains the upper-Eocene to lower Miocene species Globigerina tripartita s.l.; Sample 13,CC contains Globorotalia (1.) opima opima, which ranges from the middle to upper Oligocene (Zones P.19-P.21). No other samples from Site 449 could be dated using foraminifers.

\section{Radiolarians}

Most cores lack radiolarians. A sparse assemblage, belonging to the upper Pleistocene Collosphaera tuberosa Zone of Nigrini (1971), was found at the top of Core 2 (Section 1, 44-46 cm) in an extraordinarily rich diatomaceous layer. Farther down, the core-catcher samples of Cores 6 and 7 contain well-preserved and abundant fauna (Dorcadospyris alata and Calocycletta costata Zones, respectively). Radiolarians are also present in the core-catcher sample of Core 14, but they must be attributed to caving from a higher level within Hole 449-the rare and poorly preserved forms are middle lower Miocene (Stichocorys wolffii Zone), which con- flicts with the upper Oligocene nannofossils and foraminifers in Sample 13,CC.

\section{Diatoms and Silicoflagellates}

A mass occurrence of the extremely large diatom Ethmodiscus rex was noted in the upper part of Core 2 which, on the basis of radiolarians, is upper Pleistocene. In addition, rare silicoflagellates and sponge spicules are present at this particular level.

\section{PALEOENVIRONMENT}

The distribution of calcareous fossils at Site 449 appears to be strongly influenced by their resistance to solution (nannofossils being more resistant than benthic foraminifers, planktonic foraminifers being least resistant). The only fossils in place above Core 6 are siliceous radiolarians and diatoms, indicating that this middle Miocene to Pleistocene interval was deposited below the CCD. Middle Miocene nannofossils are present in the lower portion of Core 6 and in Core 7, suggesting that the area was slightly shallower, the $C C D$ was slightly deeper, or rapid turbiditic influx of carbonates did not provide time for dissolution during this period. Cores 8 and 9 are essentially barren; the area surrounding Site 449 presumably was again below the CCD when these sediments were deposited. Nannofossils and calcareous foraminifers occur near the base of Core 10, with inplace assemblages found through Core 13 . The preservation of both fossil groups is poor in Core 10, but improves downward to Sample 13,CC, which contains a relatively diverse planktonic foraminiferal assemblage and fairly well-preserved nannofossils of the upper Oligocene. The upper Oligocene to lower Miocene sediments sampled in Cores 13 through the base of Core 10 were therefore deposited above the CCD, with the shallowest deposition, or the lowest level of the CCD, coinciding with the oldest datable sediment (Core 13).

Sample $11, \mathrm{CC}$ through Core 13 contain a diverse benthic foraminiferal assemblage (including Cibicides kullenbergi and several species of Stilostomella); the presence of this assemblage suggests a lower bathyal to abyssal depositional environment. Benthic foraminifers are too rare above Sample 11,CC to allow for precise environmental interpretation.

\section{ACCUMULATION RATES}

Although some of the cores drilled at this site are virtually barren of planktonic fossils, nevertheless, a reasonably accurate estimate of sediment accumulation rates is possible. The resulting curve (Fig. 7) reflects the uniformly pelagic character which, on a broad scale, typifies the recovered sediments; it is probably best interpreted as a straight line representing about $4 \mathrm{~m} / \mathrm{m} . \mathrm{y}$. The curve's minor variations are in all likelihood the result of short-term changes in depositional rates associated with the alternating layers of pelagic brown clays, biogenous oozes, and volcanic materials that are interspersed in the column. However, the reason that the nannofossil ooze of Unit 5 should accumulate slower $(4.3 \mathrm{~m} / \mathrm{m} . \mathrm{y}$.) than the thick pelagic clays of Units 3 and $4(7.5 \mathrm{~m} / \mathrm{m} . \mathrm{y}$.) is not clear. It is highly probable that 


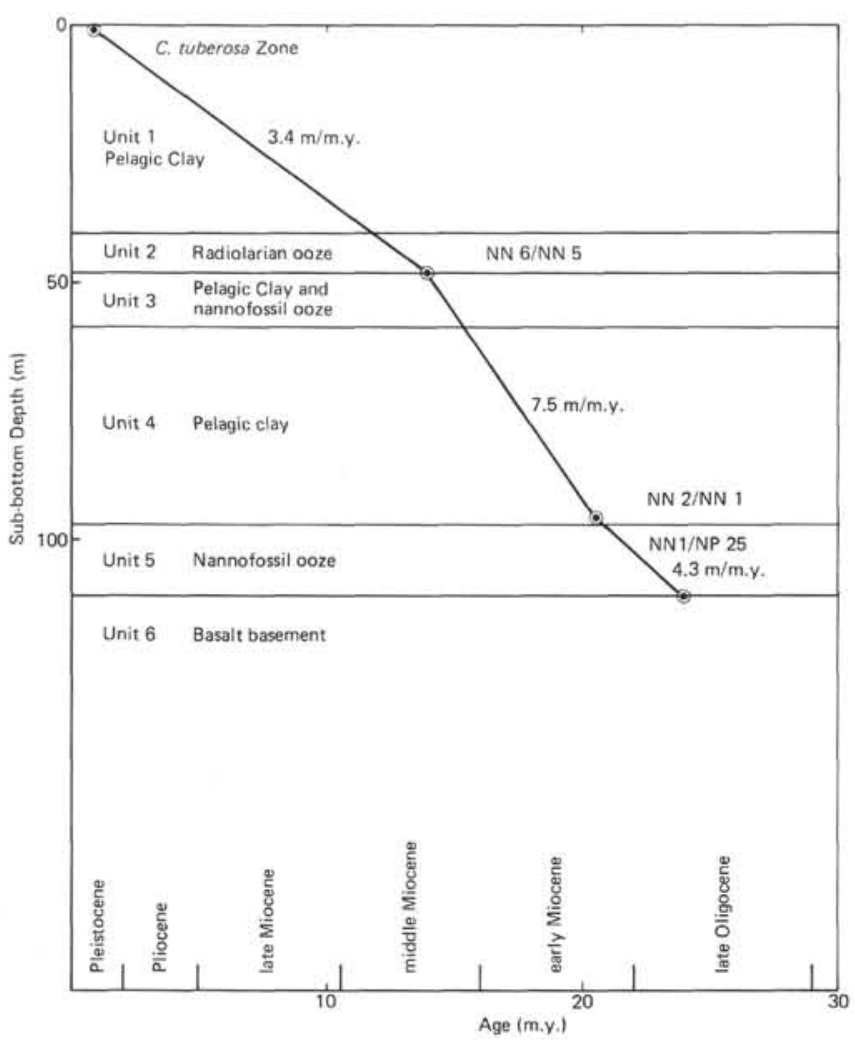

Figure 7. Accumulation rates estimated for the sedimentary sequence of Site 449. (The time-scale for the Neogene is from LaBrecque et al. [1977]; for the Oligocene, Martini's [1976] scheme was employed. Definition of the nannofossil zonal boundaries is that provided by Martini [1971]; that of the radiolarian Zone Collosphaera tuberosa is after Nigrini [1971]. Calibration to the time-scale of the nannofossil zonal boundaries follows Martini [1976].)

significant undetected erosion or nondeposition horizons are present in Unit 5.

\section{ORGANIC GEOCHEMISTRY}

No gas shows were observed in the cores recovered at Site 449; it is improbable that significant generation of hydrocarbon gases can have occurred within this sedimentary sequence. Therefore no gas analyses were made.

Twenty-three samples from Site 449 were analyzed for organic carbon and nitrogen contents using procedures outlined in the Introduction (this volume). The results from this site are given in Table 2 and plotted against sub-bottom depth in Figure 8. Within Unit 1, a gradual decrease in the amount of organic carbon is seen. A similar pattern has been previously observed at other DSDP sites, particularly those of Leg 58 in analogously lean sediments (Klein and Kobayashi, in press). This phenomenon may be attributable to bacterial activity in the upper sediment layers that recycles the organic carbon within this shallow zone. Organic carbon values for the sediments (after carbonate dissolution) from Site 449 do not show an overall trend or pattern down-hole, but seem to be partly dependent on lithology, showing different trends within each sedimentary unit. The nitrogen content, apart from the
Table 2. Organic carbon and nitrogen contents (after carbonate dissolution).

\begin{tabular}{|c|c|c|c|c|}
\hline $\begin{array}{l}\text { Lithologic } \\
\text { Unit }\end{array}$ & $\begin{array}{c}\text { Sample } \\
\text { (interval in cm) }\end{array}$ & $\begin{array}{l}\text { Organic Carbon } \\
\text { (wt. \%) }\end{array}$ & $\begin{array}{l}\text { Nitrogen } \\
\text { (wt. \%) }\end{array}$ & $\begin{array}{c}\mathrm{C}: \mathrm{N} \\
\text { (atomic ratio) }\end{array}$ \\
\hline 1 & $2-1,70-71$ & $\begin{array}{l}0.30 \\
0.29 \\
0.28\end{array}$ & $\begin{array}{l}0.084 \\
0.062 \\
0.084\end{array}$ & $\begin{array}{l}4.2 \\
5.5 \\
3.9\end{array}$ \\
\hline 1 & $2-3, \quad 4-5$ & $\begin{array}{l}0.30 \\
0.26 \\
0.31\end{array}$ & $\begin{array}{l}0.083 \\
0.082 \\
0.099\end{array}$ & $\begin{array}{l}4.2 \\
3.7 \\
3.7\end{array}$ \\
\hline 1 & $3-1, \quad 40-41$ & $\begin{array}{l}0.25 \\
0.24 \\
0.23\end{array}$ & $\begin{array}{l}0.072 \\
0.073 \\
0.079\end{array}$ & $\begin{array}{l}4.1 \\
3.8 \\
3.4\end{array}$ \\
\hline 1 & $3-3, \quad 4-5$ & $\begin{array}{l}0.26 \\
0.21 \\
0.27\end{array}$ & $\begin{array}{l}0.071 \\
0.066 \\
0.078\end{array}$ & $\begin{array}{l}4.3 \\
3.7 \\
4.1\end{array}$ \\
\hline 1 & $4-1, \quad 70-71$ & $\begin{array}{l}0.20 \\
0.24 \\
0.14\end{array}$ & $\begin{array}{l}0.032 \\
0.032 \\
0.026\end{array}$ & $\begin{array}{l}7.3 \\
8.8 \\
6.3\end{array}$ \\
\hline 1 & $4-3,23-24$ & $\begin{array}{l}0.15 \\
0.15 \\
0.13\end{array}$ & $\begin{array}{l}0.023 \\
0.015 \\
0.013\end{array}$ & $\begin{array}{r}7.6 \\
11.7 \\
11.7\end{array}$ \\
\hline 1 & $5-1, \quad 60-61$ & $\begin{array}{l}0.11 \\
0.13 \\
0.13\end{array}$ & $\begin{array}{l}0.016 \\
0.016 \\
0.015\end{array}$ & $\begin{array}{r}8.0 \\
9.5 \\
10.1\end{array}$ \\
\hline 1 & $5-3,50-51$ & $\begin{array}{l}0.16 \\
0.14 \\
0.14\end{array}$ & $\begin{array}{l}0.019 \\
0.016 \\
0.017\end{array}$ & $\begin{array}{r}9.9 \\
10.2 \\
9.6\end{array}$ \\
\hline 1 & $6-1,120-121$ & $\begin{array}{l}0.29 \\
0.25 \\
0.25\end{array}$ & $\begin{array}{l}0.023 \\
0.020 \\
0.024\end{array}$ & $\begin{array}{l}14.8 \\
14.6 \\
12.2\end{array}$ \\
\hline 2 & $6-3,117-118$ & $\begin{array}{l}0.20 \\
0.18 \\
0.23\end{array}$ & $\begin{array}{l}0.018 \\
0.016 \\
0.019\end{array}$ & $\begin{array}{l}13.0 \\
13.2 \\
14.2\end{array}$ \\
\hline 3 & $7-1, \quad 16-17$ & $\begin{array}{l}0.24 \\
0.24 \\
0.32\end{array}$ & $\begin{array}{l}0.052 \\
0.050 \\
0.059\end{array}$ & $\begin{array}{l}5.4 \\
5.6 \\
6.3\end{array}$ \\
\hline 3 & $7-5, \quad 94-95$ & $\begin{array}{l}0.24 \\
0.24 \\
0.15\end{array}$ & $\begin{array}{l}0.015 \\
0.016 \\
0.015\end{array}$ & $\begin{array}{l}18.7 \\
13.3 \\
11.7\end{array}$ \\
\hline 4 & $8-3,80-81$ & $\begin{array}{l}0.24 \\
0.17 \\
0.27\end{array}$ & $\begin{array}{l}0.015 \\
0.015 \\
0.014\end{array}$ & $\begin{array}{l}18.7 \\
13.3 \\
22.6\end{array}$ \\
\hline 4 & $9-1,80-81$ & $\begin{array}{l}0.26 \\
0.27\end{array}$ & $\begin{array}{l}0.015 \\
0.019\end{array}$ & $\begin{array}{l}20.3 \\
16.6\end{array}$ \\
\hline 4 & $10-1,49-50$ & $\begin{array}{l}0.15 \\
0.13\end{array}$ & $\begin{array}{l}0.022 \\
0.020\end{array}$ & $\begin{array}{l}8.0 \\
7.6\end{array}$ \\
\hline 4 & $10-6, \quad 22-23$ & $\begin{array}{l}0.23 \\
0.21 \\
0.22\end{array}$ & $\begin{array}{l}0.018 \\
0.018 \\
0.024\end{array}$ & $\begin{array}{l}14.9 \\
13.7 \\
10.7\end{array}$ \\
\hline 4 & $11-3, \quad 9-10$ & $\begin{array}{l}0.33 \\
0.36 \\
0.36\end{array}$ & $\begin{array}{l}0.019 \\
0.020 \\
0.021\end{array}$ & $\begin{array}{l}20.3 \\
21.6 \\
20.1\end{array}$ \\
\hline 4 & $11-5, \quad 53-55$ & $\begin{array}{l}0.47 \\
0.43 \\
0.42\end{array}$ & $\begin{array}{l}0.022 \\
0.026 \\
0.024\end{array}$ & $\begin{array}{l}25.0 \\
19.4 \\
20.5\end{array}$ \\
\hline 4 & $12-1,140-141$ & $\begin{array}{l}0.18 \\
0.24 \\
0.19\end{array}$ & $\begin{array}{l}0.013 \\
0.017 \\
0.013\end{array}$ & $\begin{array}{l}16.2 \\
16.5 \\
17.1\end{array}$ \\
\hline 5 & $12-3,40-41$ & $\begin{array}{l}0.44 \\
0.47\end{array}$ & $\begin{array}{l}0.033 \\
0.031\end{array}$ & $\begin{array}{l}15.6 \\
17.7\end{array}$ \\
\hline 5 & $13-1, \quad 26-27$ & $\begin{array}{l}0.10 \\
0.13\end{array}$ & $\begin{array}{l}0.009 \\
0.011\end{array}$ & $\begin{array}{l}13.0 \\
13.8\end{array}$ \\
\hline 5 & $13-3, \quad 48-49$ & $\begin{array}{l}0.30 \\
0.27\end{array}$ & $\begin{array}{l}0.018 \\
0.016\end{array}$ & $\begin{array}{l}19.5 \\
21.9\end{array}$ \\
\hline 5 & $13-6,100-101$ & $\begin{array}{l}0.15 \\
0.13\end{array}$ & $\begin{array}{l}0.013 \\
0.010\end{array}$ & $\begin{array}{l}13.5 \\
15.2\end{array}$ \\
\hline
\end{tabular}




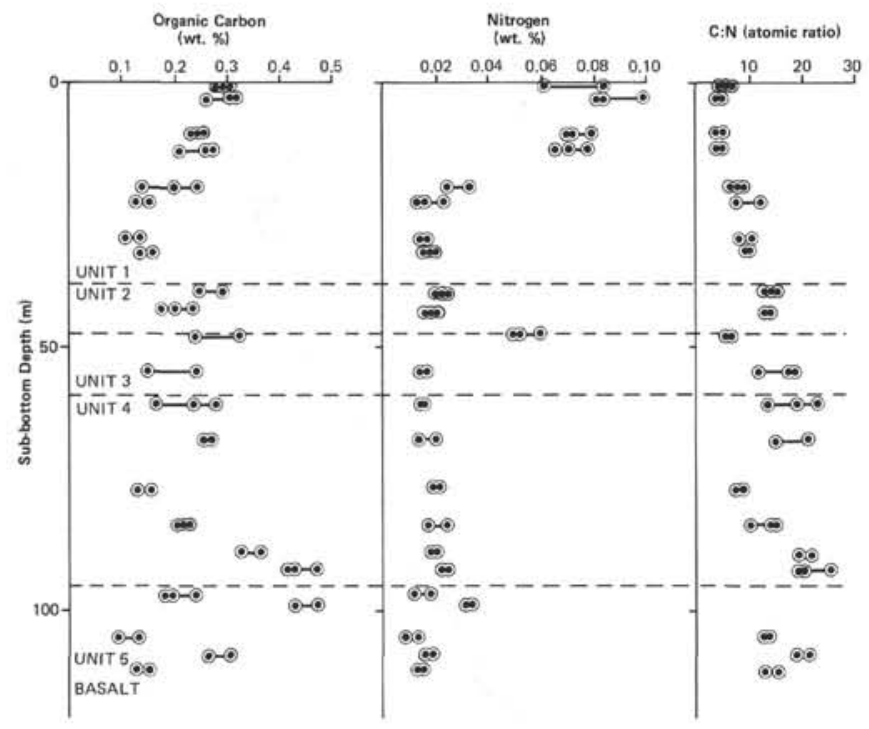

Figure 8. Results of organic carbon and nitrogen analyses plotted versus sub-bottom depth in meters.

uppermost 15 meters, where it averages 0.075 wt. $\%$ of the sediment, shows little deviation from the range 0.01 to $0.03 \mathrm{wt}$. $\%$. The sharp drop in nitrogen content between Section 3-3 and Section 4-1 does not reflect a lithologic change. No continuous trend is discernible in the C:N ratio with depth, except for a gradual increase from 5 to 15 within the uppermost 40 meters of the sequence.

Rock Eval analyses were made by methods described in the Introduction (this volume). The results of these Rock Eval analyses are summarized in Table 3. Anomalous $S_{2}$ peaks that maximize at $550^{\circ}$ appear in analyses of the pelagic clays and radiolarian oozes of Units 1, 2, and 4 and resemble the peaks of analyses of pelagic clays from Site 447 . These $S_{2}$ peaks do not appear to result from pyrolyzable organic matter but are caused by an unidentified phenomenon associated with these particular unconsolidated lithologies. None of the other sediments, especially the nannofossil oozes of Unit 5, give significant hydrocarbon responses; these are effectively devoid of pyrolyzable organic matter.

The sediments at Site 449, like those of Sites 447 and 448 , appear to be almost barren of organic matter; therefore they are of limited organic geochemical in-

Table 3. Qualitative estimate of the relative amounts of free hydrocarbons, bound hydrocarbons, and $\mathrm{CO}_{2}$ from kerogen (and carbonate-rich sediments) based upon sizes of $S_{1}, S_{2}$, and $S_{3}$, respectively, from Rock Eval analyses.

\begin{tabular}{lcccc}
\hline $\begin{array}{c}\text { Lithologic } \\
\text { Unit }\end{array}$ & $\begin{array}{c}\text { No. of } \\
\text { Samples }\end{array}$ & $\begin{array}{c}\text { Free } \\
\text { Hydrocarbon } \\
\left(S_{1}\right)\end{array}$ & $\begin{array}{c}\text { Bound } \\
\text { Hydrocarbon } \\
\left(S_{2}\right)\end{array}$ & $\begin{array}{c}\mathrm{CO}_{2} \text { from } \\
\text { Kerogen } \\
\left(S_{3}\right)\end{array}$ \\
\hline Units 1 and 2 & 10 & $-1+$ & +++ & - \\
Unit 4 & 9 & + & $-1+++$ & - \\
Unit 5 & 4 & - & - & - \\
\hline
\end{tabular}

Note: $-=$ undetectable, $-1+=$ undetectable to minor, $+=$ minor, $-1+++=$ undetectable to major, and $+++=$ major relative amounts. terest. It does appear, however, that within the uppermost 30 meters of the sedimentary sequence, bacterial activity may have occurred.

\section{INORGANIC CHEMISTRY OF INTERSTITIAL WATER}

Four samples-from Sections 2-2, 5-1, 8-4, and 11-4-were collected for interstitial water analyses according to the standard shipboard procedures described in the Introduction (this volume). The results are given in Figure 9. Apart from the chlorinity, which shows a slight increase, the inorganic parameters remain virtually constant with depth.

\section{IGNEOUS PETROGRAPHY}

Basaltic basement was encountered at a depth of 111.0 meters sub-bottom and was continuously cored to 151.5 meters. As a result of poor hole stability, drilling was terminated after penetrating 40.5 meters of the basalt of Unit 6 . The sediment immediately overlying the basement consists of a mixture of nannofossil ooze with lithified patches of nannofossil chalk (Zone NP 25, upper Oligocene). The relationship between the uppermost basalt and these overlying sediments is not clear, but the absence of a simple chilled contact and the presence of relatively small, cognate, subspherical fragments of pillow basalt at the contact could result either from fault brecciation or simply from very poor drilling conditions. The pillow basalts in Cores 14 and 15 are so fragmented that coherent pillow structures are difficult to recognize (Figure 10).

Unit 6 is a plagioclase-olivine-spinel-phyric tholeiitic basalt, which may be divided into two sub-units based on flow structure. These two sub-units are indistinguishable from MOR basalts based upon petrographic and $\mathrm{X}$-ray fluorescence (XRF) chemical criteria.

Sub-unit 6a, 23.5 meters thick (111.0-134.5 m), consists of pillow basalts. The uppermost 13.0 meters are very glassy; of the 96 fragments recovered $(15 \mathrm{~cm}$ max. and 5-6 cm avg. length), one-third have glassy zones, probably indicating a relatively small pillow size. Both the rock and glass fragments are cemented in a palagonitic matrix. The lowermost 10.5 meters are relatively glass poor and may represent larger pillows.

Sub-unit $6 \mathrm{~b}$, more than 17 meters thick (134.5-151.5 $\mathrm{m})$, contains fewer olivine and spinel phenocrysts than does Sub-unit $6 \mathrm{a}$. The absence of glass and the relatively coarse grains in this interval suggest that Sub-unit $6 \mathrm{~b}$ is a flow; however, two possible quenched zones exist that may be large pillow margins or separate massive flow contacts.

The total abundance of phenocrysts and groundmass constituents are given as percentages of the whole rock (e.g., the rock consists of $10 \%$ phenocrysts, $5 \%$ vesicles, and $85 \%$ groundmass), whereas the abundance of individual phenocrysts or groundmass constituents are given as percentages of the total phenocrysts or total groundmass constituents (e.g., the phenocrysts consist of plagioclase $[60 \%, 0.8 \mathrm{~mm}]$ and olivine $[40 \%, 0.4$ $\mathrm{mm}$, altered to green smectite]; the groundmass consists of plagioclase [50\%], both pyroxenes [20\%], opaques [5\%], and glass $[25 \%]$ ). 


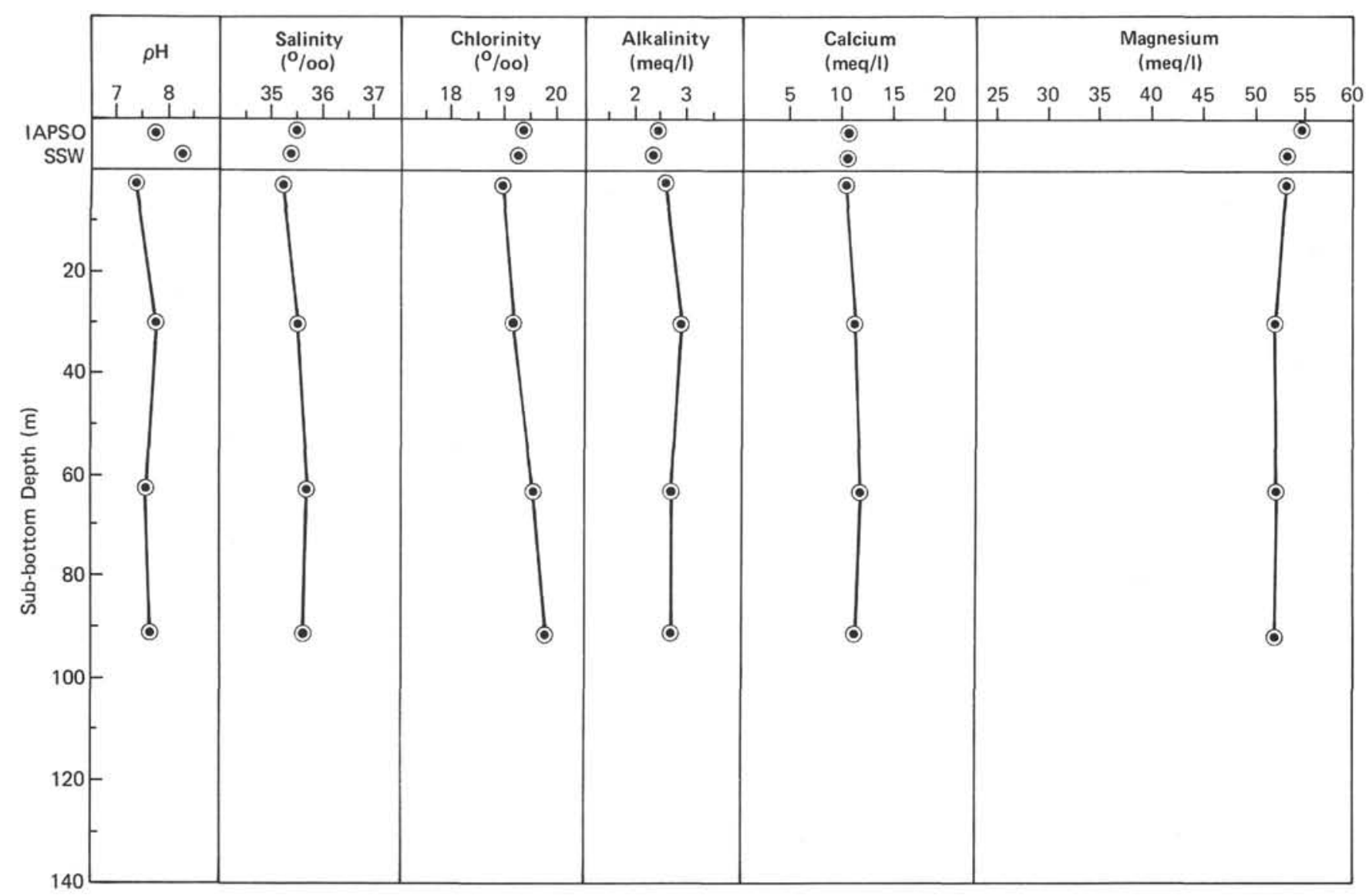

Figure 9. Results of analyses of interstitial water from sediment samples plotted versus sub-bottom depth in meters. (IAPSO standard and a surface sea-water sample, SSW, are shown for comparison.)

The plagioclase-olivine-spinel-phyric basalt of Subunit $6 \mathrm{a}$ is a gray to pale brown, fine-grained pillow lava with sparse, irregular vesicles $(3-5 \%, 0.5-1 \mathrm{~mm}$, rarely filled with carbonate). The inner parts of the pillows have a hyalopilitic texture and contain less than $10 \%$ phenocrysts of euhedral, oscillatory-zones plagioclase phenocrysts $\left(\sim 80 \%, 0.5-2.0 \mathrm{~mm}\right.$ long, $\left.\sim \mathrm{An}_{70-75}\right)$ and sparse olivine and spinel. The groundmass consists of plagioclase laths $(30 \%, 0.2-0.4 \mathrm{~mm}$ long), granular anhedral clinopyroxene $(10 \%, 0.05-0.1 \mathrm{~mm})$, sparse olivine, and devitrified glass (60\%). A thin section of the marginal glass zone reveals a hyalopilitic groundmass that is composed of acicular microlitic plagioclase $(0-30 \%)$ and devitrified glass $(70-90 \%)$. The $8 \%$ of phenocrysts consist of euhedral, oscillatory-zoned plagioclase $\left(60 \%, 0.4-1.2 \mathrm{~mm}, \mathrm{An}_{45}\right)$ and euhedral, fresh olivine $\left(40 \%, 0.4-0.8 \mathrm{~mm}, 2 \mathrm{~V}=+90^{\circ}\right)$ containing numerous octahedral chrome spinels $(0.01-0.02 \mathrm{~mm})$.

The Sub-unit $6 \mathrm{~b}$ flow has a coarse-grained, gray to pale brown, pilotaxitic to intersertal interior. The $3 \%$ of phenocrysts consist of lathlike plagioclase $(<90 \%$, $0.3-0.5 \mathrm{~mm}$ ) and sparse olivine and spinel. The groundmass consists of acicular plagioclase laths $(40 \%, 0.2-4.0$ $\left.\mathrm{mm}, \sim \mathrm{An}_{40-50}\right)$, sheaf-like clinopyroxene $(40 \%, 0.2-1.0$ $\mathrm{mm})$, skeletal opaque minerals $(2 \%, 0.2-0.5 \mathrm{~mm})$, euhedral, sparse olivine $(0.1-0.4 \mathrm{~mm})$, and glass
(5-10\%). Empty vesicles $(0.2-1.0 \mathrm{~mm})$ comprise $20 \%$ of the rock.

Most of the basalts show a moderate amount of lowtemperature alteration that is extensively developed in pillow margins and in pockets between the pillows. Low-temperature alteration minerals are clays (smectite), Fe-hydroxides, carbonates, and zeolites. Olivine and glass are more extensively altered than are clinopyroxene, plagioclase, and opaque minerals.

\section{METAMORPHIC PETROGRAPHY}

In the 40.5 meters of weathered basalts (111.0-151.5 m sub-bottom), which fortunately contain very fresh glassy rims, there is no indication of hydrothermal activity or metamorphism. The sediments obviously postdate the extrusion and thus no contact metamorphic effects are involved.

\section{CONTACT RELATIONS AND STRATIGRAPHY}

In the 40.5-meter interval of basalt drilled between the lowermost sediments ( $110.0 \mathrm{~m}$ sub-bottom) and the bottom of Hole 449, we encountered pillow lavas and massive flows. However, within this sequence, core recovery was poor and the basalt consisted of small rubbly pieces; this material did not provide sufficient contact relations for studiy. At the sediment/basalt inter- 


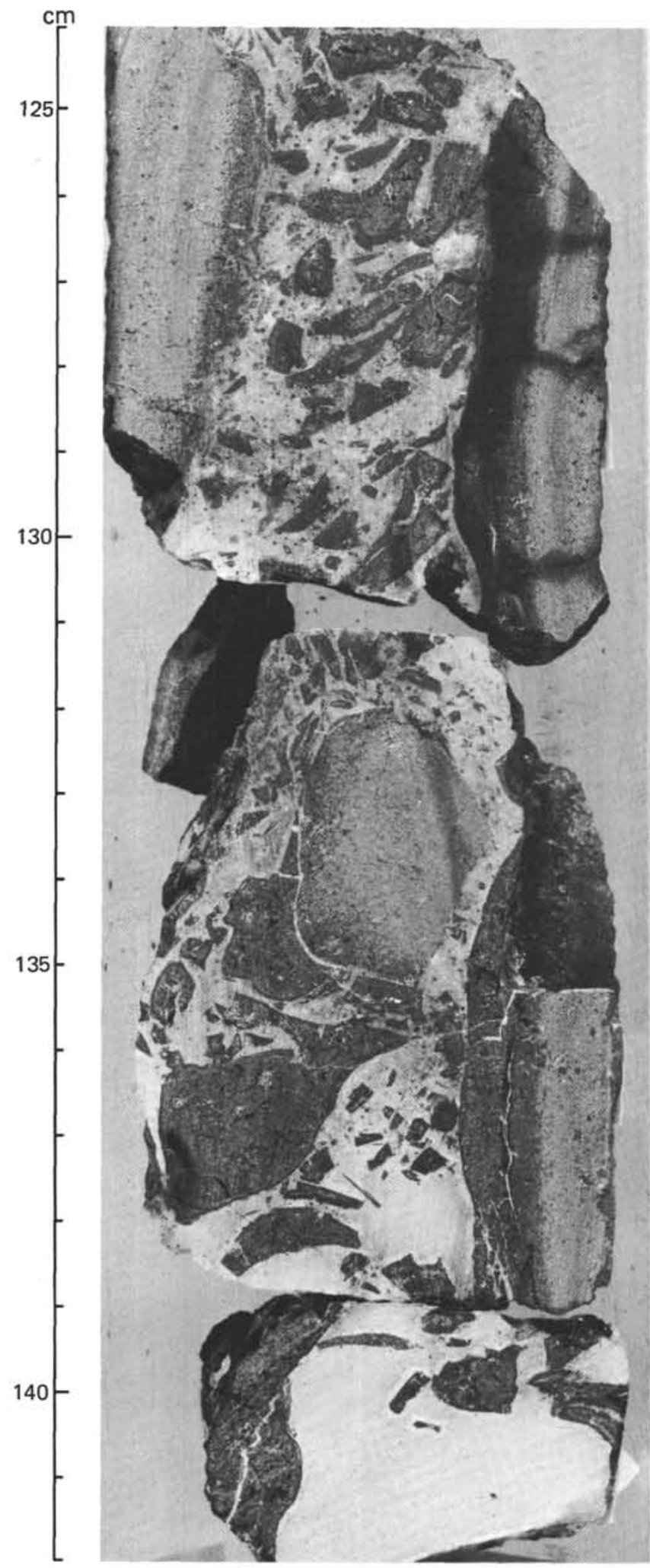

Figure 10. Highly fragmented pillow basalts cemented with calcium carbonate that largely appears to be recrystallized nannofossil chalk. face, the basalt fragments have been cemented together by calcite and zeolites(?) across an interval several meters thick, but below that interval fractures have been left open. No evidence was recovered to suggest that sediments were interbedded with the basalts.

\section{PALEOMAGNETISM}

No paleomagnetic samples were collected from Site 449. The sediment column at this site is a red-brown pelagic clay that normally gives unreliable paleomagnetic results (Foster, 1972). In addition, the sediment cores showed significant drilling disturbance. The volcanic units recovered also appeared unsuitable for paleomagnetic study; alteration, specifically oxidation of iron oxides, was pervasive throughout, making them poor choices for study.

\section{PHYSICAL PROPERTIES}

Physical properties were measured on only a few samples from Hole 449 because of the severe disturbance of the pelagic clays and nannofossil oozes in the upper part of the hole. Sonic velocity measured on the same type, but less disturbed, sediments in Cores 11, 12, and 13 immediately overlying the basaltic basement averages about $1.55 \mathrm{~km} / \mathrm{s}$ (Table 4, Fig. 11). Wet-bulk density of the less disturbed sediments ranges from 1.23 to $1.40 \mathrm{~g} / \mathrm{cm}^{3}$. The only exception is a thin $2-\mathrm{cm}$ bed of lithified mudstone in Section 11-3, which has a velocity of $2.14 \mathrm{~km} / \mathrm{s}$ and a wet-bulk density of $1.67 \mathrm{~g} / \mathrm{cm}^{3}$.

In the basalts, velocities ranged from about 3.9 to 4.3 $\mathrm{km} / \mathrm{s}$. The acoustic impedance in these basalts is typical, ranging from 10.0 to $11.2 \times 10^{5} \mathrm{~g} /\left(\mathrm{cm}^{2} \mathrm{~s}\right)$.

\section{GEOPHYSICS}

The Parece Vela Basin, a back-arc or interarc basin, is situated between two aseismic remnant arcs: the Palau-Kyushu Ridge to the west and the West Mariana Ridge to the east. The basin is divided into approximately equal halves by the north-south trending Parece Vela Rift, which actually consists of a series of offset deep troughs located along a line extending northward from the Yap Trench. Site 449 is located about $300 \mathrm{~km}$ west of the rift and about $100 \mathrm{~km}$ east of the PalauKyushu Ridge.

Describing the crustal structure of the West Philippine Sea, Murauchi et al. (1968) present data from two seismic refraction lines in the western Parece Vela Basin. Both lines reveal a low-velocity $(3.1-3.7 \mathrm{~km} / \mathrm{s})$ uppermost crustal layer (Layer 2a?) overlying a more normal-velocity $(4.3-5.1 \mathrm{~km} / \mathrm{s})$ oceanic Layer 2 (Layer $2 \mathrm{~b}$ ?), in turn overlying a normal-velocity $(6.8-7.0 \mathrm{~km} / \mathrm{s})$ oceanic Layer 3 above a slightly high-velocity (8.2-8.5 $\mathrm{km} / \mathrm{s}$ ) mantle. It is the low-velocity, uppermost crustal layer that is of interest here. On the one hand, singlechannel seismic-reflection profiling has shown lcwvelocity, acoustically transparent sediments are generally very thin (100 $\mathrm{m}$ or less), perhaps with the exception of isolated ponds in topographic depressions. On the other hand, preliminary results from multichannel seismic data indicated 300 meters of sediment overlying a $4.21-\mathrm{km} / \mathrm{s}$ basement in the vicinity of the drill site. 
Table 4. Physical properties of sediments and igneous rocks from Hole 449.

\begin{tabular}{|c|c|c|c|c|c|c|c|c|c|c|c|}
\hline \multirow{3}{*}{$\begin{array}{c}\text { Sample } \\
\text { (hole-core-section) }\end{array}$} & \multirow{3}{*}{$\begin{array}{l}\text { Sub-bottom } \\
\text { Depth } \\
\text { (m) }\end{array}$} & & & & \multicolumn{3}{|c|}{ Wet-Bulk Density } & \multirow{3}{*}{$\begin{array}{c}\text { Water } \\
\text { Content } \\
(\%)\end{array}$} & \multirow{3}{*}{$\begin{array}{l}\text { Porosity } \\
(\%)\end{array}$} & \multirow{3}{*}{$\begin{array}{c}\text { Calculated } \\
\text { Grain } \\
\text { Density } \\
\left(\mathrm{g} / \mathrm{cm}^{3}\right)\end{array}$} & \multirow{3}{*}{$\begin{array}{c}\text { Acoustic } \\
\text { Impedance } \\
{\left[\times 10^{5} \mathrm{~g} /\left(\mathrm{cm}^{2} \mathrm{~s}\right)\right]}\end{array}$} \\
\hline & & \multicolumn{3}{|c|}{ Sonic Velocity } & \multirow{2}{*}{$\begin{array}{c}\text { Gravimetric } \\
\left(\mathrm{g} / \mathrm{cm}^{3}\right)\end{array}$} & \multirow{2}{*}{$\begin{array}{l}\text { Continuous } \\
\text { GRAPE } \\
\text { (section } \\
\text { averages) } \\
\left(\mathrm{g} / \mathrm{cm}^{3}\right)^{b}\end{array}$} & \multirow{2}{*}{$\begin{array}{l}\text { Special } \\
2-m i n \\
\text { GRAPE } \\
\left(\mathrm{g} / \mathrm{cm}^{3}\right)^{\mathrm{b}}\end{array}$} & & & & \\
\hline & & Horizontal & & Vertical & & & & & & & \\
\hline $449-2-1$ & 0.75 & - & - & - & - & 1.28 & - & - & - & - & - \\
\hline $449-2-2$ & 2.25 & - & - & - & - & 1.28 & - & - & - & - & - \\
\hline $449-2-2$ & 2.95 & $=$ & $=$ & $\bar{z}$ & $\bar{z}$ & $\overline{1.30}$ & $\bar{z}$ & 64.80 & $\overline{-}$ & - & - \\
\hline $\begin{array}{l}449-2-3 \\
449-3-2\end{array}$ & $\begin{array}{r}3.75 \\
11.75\end{array}$ & $\bar{z}$ & $\overline{-}$ & $\bar{z}$ & $\bar{z}$ & $\begin{array}{l}1.30 \\
1.32\end{array}$ & $\overline{-}$ & $\bar{z}$ & $\overline{-}$ & $\bar{z}$ & $\bar{z}$ \\
\hline $449-3-3$ & 13.25 & - & - & - & & 1.33 & - & - & - & - & - \\
\hline $449-3-4$ & $\begin{array}{l}14.75 \\
10.75\end{array}$ & - & - & - & - & 1.32 & - & - & - & - & - \\
\hline $\begin{array}{l}449-4-1 \\
449-4-2\end{array}$ & $\begin{array}{l}19.75 \\
21.25\end{array}$ & - & $=$ & - & - & 1.28 & - & - & - & - & - \\
\hline $\begin{array}{l}449-4-2 \\
449-4-3\end{array}$ & $\begin{array}{l}21.25 \\
22.75\end{array}$ & $\bar{z}$ & $\bar{z}$ & $\overline{-}$ & $\overline{-}$ & 1.25 & - & - & $=$ & $=$ & - \\
\hline $449-4-3$ & & & - & & - & 1.28 & - & - & - & - & - \\
\hline $449-4-4$ & $\begin{array}{l}24.25 \\
25.75\end{array}$ & - & - & - & - & 1.26 & - & - & - & - & - \\
\hline $\begin{array}{l}449-4-5 \\
449-5-5\end{array}$ & $\begin{array}{l}25.75 \\
\end{array}$ & - & - & - & - & 1.26 & - & - & - & - & - \\
\hline $\begin{array}{l}449-5-5-1 \\
449-5-1\end{array}$ & $\begin{array}{l}29.25 \\
29.95\end{array}$ & $\bar{z}$ & $\overline{-}$ & $\bar{z}$ & $\bar{z}$ & 1.26 & $\bar{z}$ & $6 \overline{694}$ & $\overline{-}$ & $\bar{z}$ & - \\
\hline $449-5-2$ & $\begin{array}{l}29.95 \\
30.75\end{array}$ & $\overline{-}$ & $\overline{-}$ & $\overline{-}$ & $\bar{z}$ & $1 . \overline{26}$ & $\overline{-}$ & $\stackrel{66.94}{-}$ & $\overline{-}$ & $\bar{z}$ & $\overline{-}$ \\
\hline $449-5-3$ & 32.25 & - & - & - & - & 1.24 & - & - & - & - & - \\
\hline $449-5-4$ & 33.75 & - & - & - & - & 1.23 & - & - & - & - & - \\
\hline 449-5-5 & 35.25 & - & - & - & - & 1.21 & - & - & - & - & - \\
\hline $449-6-2$ & $\begin{array}{r}40.25 \\
41.75\end{array}$ & - & - & - & - & 1.23 & - & - & - & - & - \\
\hline $449-6-3$ & 41.75 & - & - & - & - & 1.22 & - & - & - & - & - \\
\hline $\begin{array}{l}449-6-4 \\
449-8-1\end{array}$ & $\begin{array}{l}43.25 \\
57.75\end{array}$ & $\bar{z}$ & $\bar{z}$ & - & $\bar{z}$ & 1.19 & $\overline{-}$ & $\bar{z}$ & $\overline{-}$ & - & - \\
\hline $\begin{array}{l}4499-8-1 \\
449-8-3\end{array}$ & $\begin{array}{l}57.75 \\
60.75\end{array}$ & $\bar{z}$ & $\bar{z}$ & $\bar{z}$ & $\bar{z}$ & $\begin{array}{l}1.23 \\
1.22\end{array}$ & $\bar{z}$ & $\bar{z}$ & $\bar{z}$ & $\overline{-}$ & $\bar{z}$ \\
\hline $449-8-4$ & 62.25 & - & - & - & - & 1.24 & - & - & - & $\overline{-}$ & $\overline{-}$ \\
\hline $449-8-4$ & 62.95 & - & - & - & - & - & - & 71.48 & - & - & - \\
\hline $449-8-5$ & 63.75 & - & - & - & - & 1.22 & - & - & - & - & - \\
\hline $\begin{array}{l}449-8-8 \\
449-9-1\end{array}$ & $\begin{array}{l}65.25 \\
67.25\end{array}$ & $\overline{-}$ & $=$ & $\overline{-}$ & $\bar{z}$ & $\begin{array}{l}1.21 \\
1.24\end{array}$ & $=$ & $\bar{z}$ & $=$ & $=$ & $\overline{-}$ \\
\hline $\begin{array}{l}444-9-1 \\
449-9-2\end{array}$ & $\begin{array}{l}67.25 \\
68.75\end{array}$ & $=$ & $\bar{z}$ & $=$ & $=$ & $\begin{array}{l}1.24 \\
1.26\end{array}$ & $=$ & $\bar{z}$ & $=$ & $\bar{z}$ & $\bar{z}$ \\
\hline $449-10-1$ & 76.75 & - & - & - & - & 1.23 & - & - & - & $\bar{z}$ & $\bar{z}$ \\
\hline $449-10-3$ & 79.75 & - & - & - & - & 1.22 & - & - & - & - & - \\
\hline $449-10-5$ & 82.75 & - & - & - & - & 1.25 & - & - & - & - & - \\
\hline 449-11-1 & $\begin{array}{l}86.25 \\
89.25\end{array}$ & - & - & - & - & 1.26 & $\overline{-}$ & $\overline{-}$ & - & $\bar{z}$ & $=$ \\
\hline $449-11-3$ & $\begin{array}{l}89.25 \\
89.29\end{array}$ & $\overline{745}$ & $\overline{-}$ & $\overline{125}$ & $=$ & 1.26 & $=$ & - & - & - & $-\overline{35}$ \\
\hline $449-11-3$ & 89.29 & 2.145 & - & 2.125 & - & - & - & - & - & - & 3.59 \\
\hline $449-11-3$ & 89.30 & - & - & - & 1.673 & - & $=$ & 34.91 & 58.38 & 2.616 & - \\
\hline $\begin{array}{l}449-11-4 \\
449-11-5\end{array}$ & $\begin{array}{l}91.45 \\
92.25\end{array}$ & $=$ & $\bar{z}$ & $\bar{z}$ & $=$ & $1 . \overline{25}$ & $\bar{z}$ & $\begin{array}{c}64.92 \\
-\end{array}$ & $=$ & $=$ & $\bar{z}$ \\
\hline $449-11-5$ & 92.68 & 1.556 & - & 1.570 & - & - & - & $\bar{z}$ & $\bar{z}$ & $\overline{-}$ & $\overline{1.93}$ \\
\hline $449-11-5$ & 92.69 & - & - & - & 1.231 & - & - & 68.95 & 84.87 & 2.526 & - \\
\hline $449-12-1$ & 95.75 & - & - & - & - & 1.33 & - & - & - & - & - \\
\hline $\begin{array}{l}449-12-3 \\
449-12-3\end{array}$ & $\begin{array}{l}98.67 \\
98.68\end{array}$ & 1.538 & $\bar{z}$ & 1. 4 & $\overline{3} 37$ & $\bar{z}$ & $\bar{z}$ & 55.90 & $7 \overline{76.80}$ & $2 . \overline{612}$ & 2.11 \\
\hline $\begin{array}{l}449-12-3 \\
449-12-3\end{array}$ & $\begin{array}{l}98.68 \\
98.75\end{array}$ & $\bar{z}$ & $\bar{z}$ & $\bar{z}$ & 1.374 & $1 . \overline{34}$ & $\bar{z}$ & 55.90 & 76.80 & 2.612 & $\bar{z}$ \\
\hline $449-13-1$ & 105.25 & - & - & - & - & 1.37 & - & - & - & - & $\overline{-}$ \\
\hline $449-13-3$ & 108.25 & - & - & - & - & 1.43 & - & - & - & - & - \\
\hline $449-13-5$ & $\begin{array}{l}111.25 \\
111.82\end{array}$ & $\bar{z}$ & $=$ & $\overline{1556}$ & $\overline{-}$ & 1.43 & $\bar{z}$ & $\overline{-}$ & $\overline{-}$ & $\bar{z}$ & $\overline{1.66}$ \\
\hline $\begin{array}{l}449-13-5 \\
449-13-5\end{array}$ & $\begin{array}{l}111.82 \\
111.84\end{array}$ & $\bar{z}$ & $=$ & 1.556 & $1 . \overline{403}$ & $\bar{z}$ & $\overline{-}$ & 54.19 & 76.05 & $2 . \overline{683}$ & - \\
\hline $449-13-6$ & 112.75 & $\overline{-}$ & $\overline{-}$ & $\overline{-}$ & 1.403 & $1 . \overline{46}$ & - & - & - & - & - \\
\hline 449-14-1 & 111.61 & - & $4.209 \mathrm{a}$ & - & - & - & $\overline{s i n}$ & - & - & - & - \\
\hline $\begin{array}{l}449-14-1 \\
449-14-1\end{array}$ & $\begin{array}{l}111.64 \\
112.69\end{array}$ & $\bar{z}$ & $3 . \overline{949 \mathrm{a}}$ & $=$ & $\bar{z}$ & $\overline{-}$ & 2.510 & $\bar{z}$ & $\bar{z}$ & $\overline{-}$ & $=$ \\
\hline $\begin{array}{l}449-14-2 \\
449-14-6\end{array}$ & $\begin{array}{l}112.69 \\
118.76\end{array}$ & $\bar{z}$ & - & $\overline{-}$ & $\overline{-}$ & $\bar{z}$ & $2 . \overline{349}$ & $\overline{-}$ & $\overline{-}$ & $\bar{z}$ & $\overline{-}$ \\
\hline $449-15-1$ & 114.52 & - & $4.172^{\mathrm{a}}$ & - & - & - & - & - & - & - & 10.91 \\
\hline $449-15-1$ & 114.53 & - & $\bar{n}$ & - & 2.616 & - & - & - & - & - & - \\
\hline $\begin{array}{l}444-15-2 \\
44-15-2\end{array}$ & $\begin{array}{l}115.66 \\
115.67\end{array}$ & $\overline{-}$ & 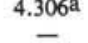 & $\overline{-}$ & $2 . \overline{609}$ & $\bar{z}$ & $\overline{-}$ & $\bar{z}$ & $\bar{z}$ & $\bar{z}$ & $\frac{11.23}{-}$ \\
\hline $449-16-2$ & 125.38 & - & $3 . \overline{967 a}$ & $\bar{z}$ & ${ }_{-}^{2.009}$ & $\overline{-}$ & - & $=$ & $\overline{-}$ & $\overline{-}$ & $\overline{10.03}$ \\
\hline $449-16-2$ & 125.39 & - & - & - & 2.529 & - & - & - & - & - & - \\
\hline
\end{tabular}

a Basalt average velocity.

b Based on an assumed grain density of $2.75 \mathrm{~g} / \mathrm{cm}^{3}$.

Prior to drilling, as the target site was approached, reflection profiles recorded on board the Challenger revealed little, if any, appreciable sediment thickness in the area previously selected for drilling. After a short survey, however, a sufficiently thick accumulation was located nearby that permitted complete burial of the bottom-hole assembly. Approximately $0.13 \mathrm{~s}$ of reflection time is indicated in the reflection profile across the site (taken during the approach) as shown in Figure 12. Because of drilling disturbance encountered in cores from Hole 449, sonic velocities were not well determined. However, assuming the reflection time of $0.13 \mathrm{~s}$ 


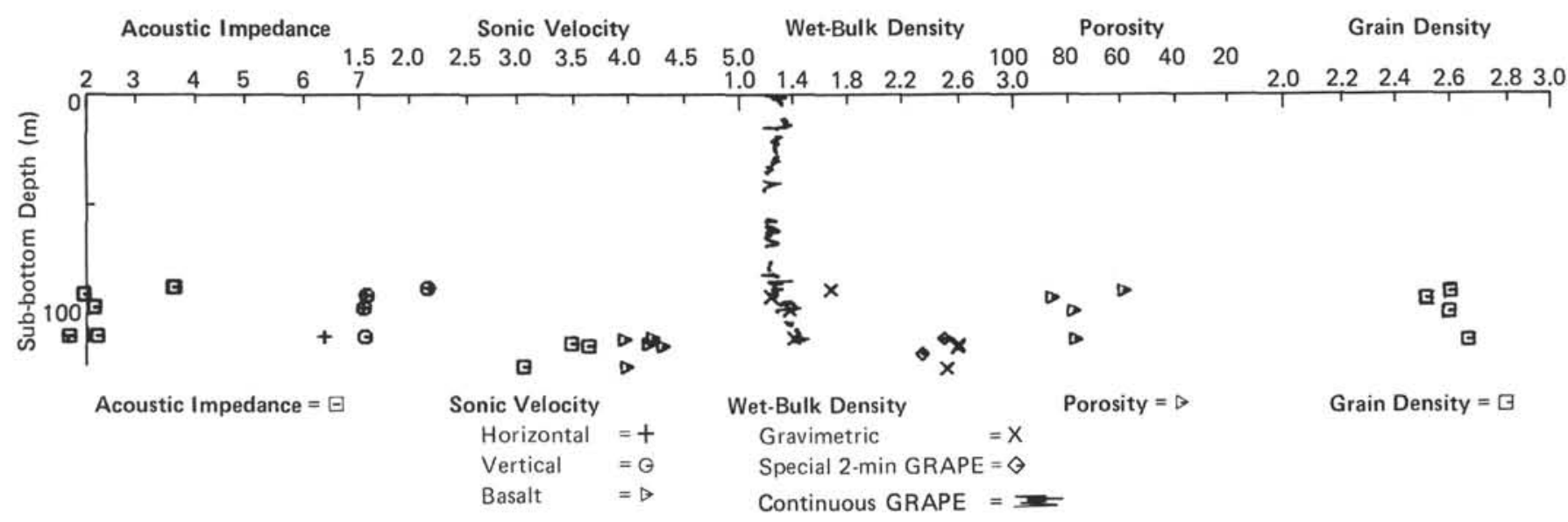

Figure 11. Physical properties of sediments and igneous rocks from Hole 449 plotted versus sub-bottom depth in meters. (Acoustic impedance is the product of velocity and bulk density. Sonic-velocity measurements include horizontal and vertical velocity of sediments and average velocity of basalts. Gravimetric determinations of wet-bulk density are shown. Special 2-minute and continuous GRAPE determinations of wet-bulk density are also shown, based on an assumed grain density of $2.75 \mathrm{~g} / \mathrm{cm}^{3}$. Porosity was determined gravimetrically, and grain density was calculated from porosity and bulk density.)

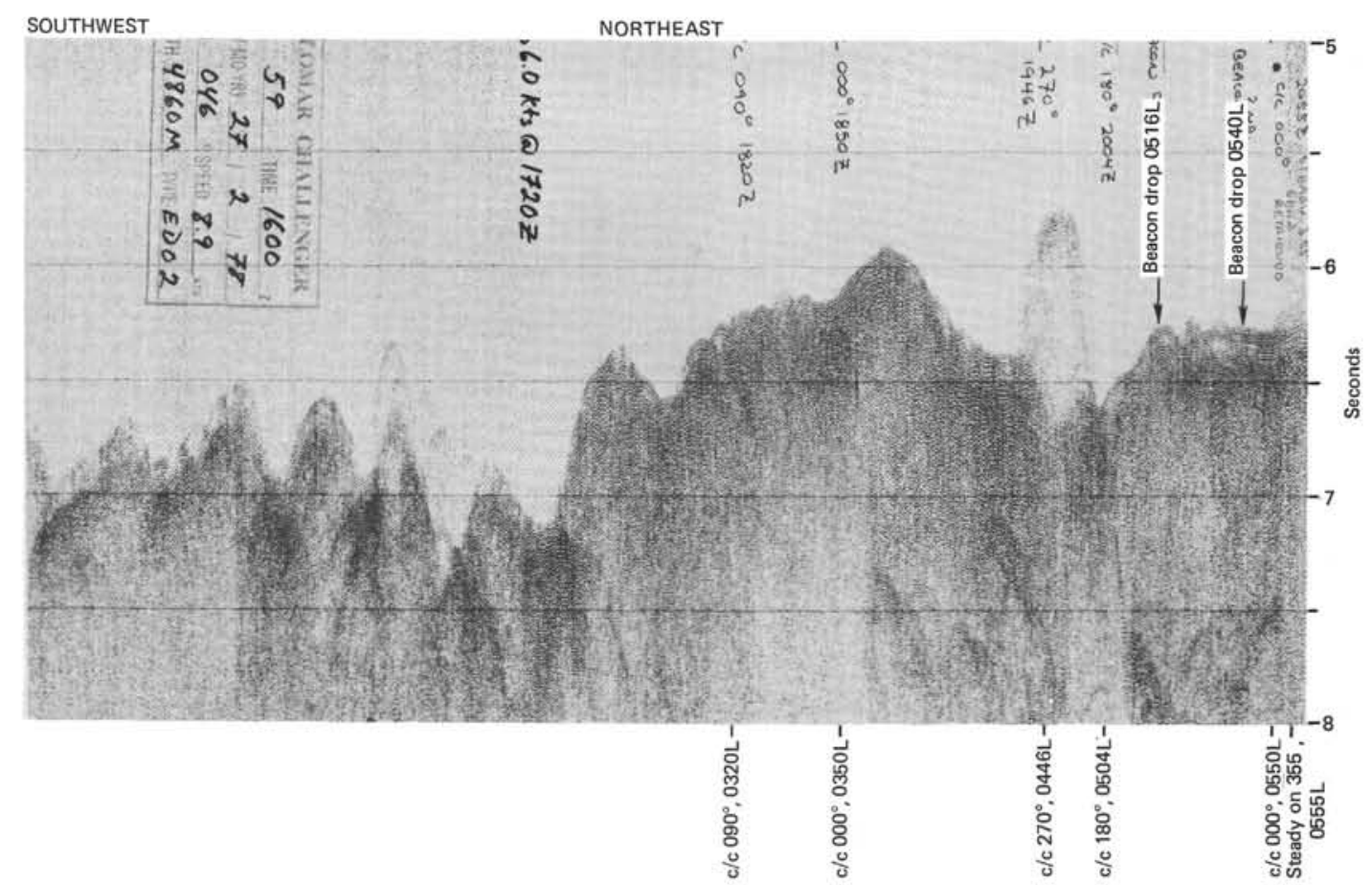

Figure 12. Seismic-reflection profile across Site 449 recorded on board the Glomar Challenger during approach to the site.

to basaltic basement has been correctly determined, an average velocity of $1.71 \mathrm{~km} / \mathrm{s}$ for the sediment column is obtained.

\section{SUMMARY AND CONCLUSIONS}

Site 449 at $18^{\circ} 01.84^{\prime} \mathrm{N}$ and $136^{\circ} 32.19^{\prime} \mathrm{E}$ was drilled with the objective of determining (1) the age and pattern of back-arc spreading that formed the rough basaltic basement of the western side of the Parece Vela Basin and (2) the metallogenic features of basin sediments and underlying basalts. Continuous coring at Hole 449 resulted in a total recovery of 93.4 meters of 151.5 meters drilled. Sediments were cored to a depth of 111.0 meters before basalt was encountered. An additional 40.5 meters of basaltic pillow lavas and massive flows were cored before the total depth was reached. Hole 449 was terminated at a total depth of 151.5 meters because of severe hole instability associated with slumping of unconsolidated pelagic clay and basalt rubble into the hole. Six lithologic units were identified; the sedimentary section comprises five units that range from the upper Oligocene to the Pleistocene. The upper Oligocene (or older) igneous unit is divided into two additional sub-units, based upon flow mechanics. 
The sedimentary section consists of:

Unit $1(0.0-40.9 \mathrm{~m})$, Pleistocene to middle Miocene dark brown and yellowish brown pelagic clay;

Unit 2 (40.9-47.5 m), middle Miocene dark yellowish brown radiolarian ooze with pumice and volcanic glass;

Unit 3 (47.5-58.5 m), middle Miocene interbedded yellowish brown to dark brown radiolarian-rich pelagic clay and yellow to brownish yellow radiolarian-bearing nannofossil ooze with pumice;

Unit 4 (58.5-97.2 m), lower Miocene to middle Miocene dark yellowish brown to very dark brown pelagic clay with pumice and ash layers; and

Unit $5(97.2-111.0 \mathrm{~m})$, lower Miocene to upper Oligocene mottled brown and yellow-brown nannofossil ooze.

The igneous section consists of two sub-units:

Sub-unit $6 \mathrm{a}(111.0-134.5 \mathrm{~m})$, plagioclase-olivine-spinelphyric pillow basalt; and

Sub-unit $6 \mathrm{~b}(134.5-151.5 \mathrm{~m})$, plagioclase-olivine-spinelphyric basalt flow.

The thin sedimentary cover over the basement appears to be a normal, uninterrupted, deep-oceanic sedimentary section. A thin layer of ferromanganese nodules collected in the core catcher of Core 1 suggests that a ferromanganese pavement may exist in the area of Site 449. Ferromanganese nodules are also present in Units 1 (Core 3), 4 (Cores 8 and 11), and 5 (Core 12). Throughout the sedimentary section, color variations of reddish browns and dark browns are related to variations in abundances of ferromanganese micronodules and other forms of iron and manganese oxides. Lighter colors are related to additions of light-colored biogenous material. Ash and pumice occur in abundance as low as the lower Miocene (Zone NN 2) and as high as the middle Miocene.

Several fossil occurrences in the sediments recovered at Site 449 are restricted to a few levels. Upper Pleistocene radiolarians are found at the top of Core $2(0-2 \mathrm{~m})$. Below a nondiagnostic interval, middle Miocene radiolarians and calcareous nannoplankton (Zone NN 6) occur in Core $6(42-45 \mathrm{~m})$. Below a barren zone, more calcareous nannoplankton (Zone NN 2) are present in Core $10(92-96 \mathrm{~m})$. The oldest nannofossils (Zone NP 25) date the sediments just above the basalt as late Oligocene.

Upper Oligocene sediments contain calcareous fossils; lower Miocene sediments do not; middle Miocene sediments again contain calcareous layers but with alternating barren layers; and middle Miocene to Pleistocene sediments again do not contain calcareous fossils. This phenomenon is interpreted as turbiditic influxes or fluctuations of the CCD with respect to the seafloor by three processes: (1) the gradual submergence of a marginal basin with age; (2) independent fluctuations of the CCD; and (3) the tectonic processes of uplift and subsidence of the ocean floor through the CCD. After the middle Miocene, the separation between the CCD and the seafloor increased with time. During times when the seafloor was above the CCD, the average sedimentation rate was about $6 \mathrm{~m} / \mathrm{m}$.y., and after the CCD was above the seafloor, the rate distinctly dropped to about $4 \mathrm{~m} / \mathrm{m} . \mathrm{y}$.

In spite of the extreme degree of topographic roughness in the area, sonic velocities of 3.9 to $4.3 \mathrm{~km} / \mathrm{s}$ measured on the basalts cored at Site 449 agree reasonably well with both the refraction velocities of 3.1 to 3.7 $\mathrm{km} / \mathrm{s}$ for Layer $2 \mathrm{a}$ and the multichannel survey velocity of $4.2 \mathrm{~km} / \mathrm{s}$.

The limited petrographic and XRF studies conducted on the basalts encountered at Site 449 indicate that they appear to be indistinguishable from oceanic tholeiites. Chemical studies of samples obtained in 1976 from dredging in the Parece Vela Basin at Site 1398 (Fig. 1) aboard the Dmitry Mendeleev can be used to make a more detailed comparison of Site 449 basalts with MOR, arc, and other marginal-basin basalts (Table 5). The major-element abundances in the Parece Vela Basin basalts are somewhat similar to MOR basalts and to other marginal-basin basalts but distinctly different from arc basalts. $\mathrm{TiO}_{2}$ values obtained by Dietrich et al. (1978) are all higher and the value obtained by Zakariadze (personal communication) is lower than typical MOR values. Although Dietrich et al. have average $\mathrm{K}_{2} \mathrm{O}$ values that are close to MOR values and to Lau Basin basalts (Hawkins, 1977), they are significantly lower than the $\mathrm{K}_{2} \mathrm{O}$ value for the Mariana Trough basalts. Zakariadze's $\mathrm{K}_{2} \mathrm{O}$ value and $\mathrm{K} / \mathrm{Rb}$ ratio are similar to those for Mariana Trough basalts, whereas Dietrich's data have higher $\mathrm{Rb}$ and/or lower $\mathrm{K}$ values. The entire question of contamination of $\mathrm{K}$ and $\mathrm{Rb}$ by sea-water and/or analytic resolution problems related to $\mathrm{Rb}$ analyses by XRF require that extreme care be used in interpreting these data. The comparison of $\mathrm{K} / \mathrm{Rb}$ and $\mathrm{K} / \mathrm{Ba}$ ratios of Lau Basin to Mariana Trough basalts suggests consistency of $\mathrm{K} / \mathrm{Rb}$ ratios but large differ-

Table 5. Major- and trace-element analyses of various basalt samples.

\begin{tabular}{|c|c|c|c|c|c|c|c|c|c|c|}
\hline \multirow[b]{2}{*}{ Station and Sample } & \multicolumn{10}{|c|}{ Major Elements (wt. \%) } \\
\hline & $\mathrm{SiO}_{2}$ & \multicolumn{2}{|c|}{$\mathrm{TiO}_{2}$} & $\mathrm{Al}_{2} \mathrm{O}_{3}$ & $\mathrm{FeO}^{\mathrm{a}}$ & $\mathrm{MgO}$ & $\mathrm{CaO}$ & $\mathrm{Na}_{2} \mathrm{O}$ & $\mathrm{K}_{2} \mathrm{O}$ & $\mathrm{P}_{2} \mathrm{O}_{5}$ \\
\hline $1398-2-1 \mathrm{~b}$ & 48.7 & \multicolumn{2}{|c|}{1.22} & !5.8 & 9.55 & 4.06 & 12.4 & 3.00 & 0.5 & 0.65 \\
\hline $1398-1 \mathrm{AC}^{\mathrm{C}}$ & 50.0 & \multicolumn{2}{|c|}{1.67} & 16.1 & 9.54 & 6.01 & 11.6 & 2.99 & 0.16 & 0.15 \\
\hline $1398-6 \mathrm{c}$ & 48.8 & \multicolumn{2}{|c|}{1.88} & 15.8 & 11.2 & 5.84 & 11.4 & 3.10 & 0.16 & 0.24 \\
\hline $1398-10 c$ & 48.2 & \multirow{2}{*}{\multicolumn{2}{|c|}{$\begin{array}{l}1.62 \\
1.60\end{array}$}} & 17.4 & 9.61 & 5.33 & 12.1 & 2.89 & 0.16 & 0.18 \\
\hline $1398-11 \mathrm{C}$ & 50.4 & & & 16.8 & 9.59 & 6.23 & 11.5 & 2.87 & 0.19 & 0.15 \\
\hline $\begin{array}{l}1398-12^{c} \\
\text { c }\end{array}$ & 50.0 & \multicolumn{2}{|c|}{1.72} & 15.8 & 10.35 & 6.09 & 11.4 & 3.06 & 0.20 & 0.16 \\
\hline $1398-17 \mathrm{c}$ & 50.2 & \multicolumn{2}{|c|}{$\begin{array}{l}1.72 \\
1.65\end{array}$} & 16.4 & 9.38 & 6.10 & 11.7 & 3.07 & 0.12 & 0.15 \\
\hline Mariana Trough basalts $\mathrm{d}$ & 49.5 & \multicolumn{2}{|c|}{1.49} & 16.6 & 8.79 & 6.81 & 11.4 & 3.23 & 0.42 & 0.16 \\
\hline Lau Basin Basaltsg & 48.0 & \multicolumn{2}{|c|}{1.0} & 16.0 & \multirow[t]{2}{*}{8.6} & 9.3 & 12.8 & 2.2 & 0.12 & 0.07 \\
\hline Average $\mathrm{MOR}^{\mathrm{e}}$ & 49.2 & \multicolumn{2}{|c|}{1.39} & 15.8 & & 8.53 & 11.1 & 2.71 & 0.26 & 0.15 \\
\hline Average Arc $f$ & 49.0 & \multicolumn{2}{|c|}{0.8} & 18.0 & \multicolumn{2}{|c|}{9.57} & 9.0 & 3.0 & 0.58 & 0.14 \\
\hline \multicolumn{11}{|c|}{ Trace Elements (ppm) } \\
\hline & $\mathrm{Ba}$ & $\mathrm{Rb}$ & Sr & $\mathrm{Zr}$ & $Y$ & $\mathrm{~K} / \mathrm{Rb}$ & $\mathrm{K} / \mathrm{Ba}$ & & & \\
\hline $1398-2-1^{b}$ & 35 & 7 & 210 & 130 & 43 & 710 & 140 & & & \\
\hline $1398-1 \mathrm{AC}$ & - & 12 & 80 & 42 & 20 & 130 & - & & & \\
\hline $1398-6 \mathrm{c}$ & - & - & - & - & - & - & - & & & \\
\hline $1398-10 \mathrm{C}$ & - & $<9$ & 136 & 125 & 41 & $>180$ & - & & & \\
\hline $1398-11 \mathrm{c}$ & - & 9 & 123 & 110 & 42 & 210 & - & & & \\
\hline $1398-12 \mathrm{c}$ & - & $<9$ & 123 & 110 & 48 & $>220$ & - & & & \\
\hline $1398-17 \mathrm{c}$ & - & $<9$ & 126 & 110 & 42 & $>130$ & $\overline{-}$ & & & \\
\hline Mariana Trough Basalts $d$ & 38 & 4.5 & 186 & - & - & 933 & 110 & & & \\
\hline Lau Basin Basaltsg & $<2$ & $<1$ & 91 & - & - & $>1200$ & 600 & & & \\
\hline Average MORe & 12 & $i$ & 123 & 100 & - & 2600 & 216 & & & \\
\hline Average Arc $^{f}$ & 95 & 4 & 250 & so & - & 1450 & 61 & & & \\
\hline
\end{tabular}


ences in $\mathrm{K} / \mathrm{Ba}$ ratios. Narrow ranges for the traceelement chemistries cannot be assigned to marginalbasin basalts, because marginal-basin basalts obviously range in composition from basin to basin and even within one basin (Hawkins, 1977).

The sequence of events from oldest to youngest at Site 449 can be summarized as follows:

1) Extrusion of tholeiitic basalt to form oceanic Layer 2a-type basement occurred just prior to deposition of upper Oligocene (NP 25) sediments. The 24 m.y. estimate of the age of the NP 25 Zone conforms well with the tentative identification of magnetic anomalies in the Western Parece Vela Basin in the Site 449 area (Langseth and Mrozowski, this volume). These data all suggest that the age of the western side of the Parece Vela Basin is considerably older than that suggested by Karig (1975) and that the age of initial formation of the basin coincides closely with the time of cessation of volcanism on the Palau-Kyushu Ridge.

2) Deposition of the normal pelagic sequence was marked by a distinct influx of ash between the early and middle Miocene, or the interval from about 20 m.y. to 13 m.y. ago. This influx can be interpreted as the result of a major period of arc volcanism east of the growing Parece Vela Basin.

3) The presence of abundant ferromanganese nodules and micronodules in the basin sediments may indicate that processes such as hydrothermal circulation during and after crust formation may have played an important role in marginal-basin metallogenesis.

4) The CCD became deeper by the middle Miocene. Deposition of calcareous oozes again at this time may record turbiditic influx, vertical tectonic fluctuations, or CCD depth fluctuations.

5) After the middle Miocene, the seafloor stayed below the CCD.

\section{REFERENCES}

Arrhenius, G., 1963. Pelagic sediments. In Hill, M. N. (Ed.), The Sea (Vol, 3): New York (Wiley), 655-727.

Berger, W. H., and Winterer, E. L., 1974. Plate stratigraphy and the fluctuating carbonate line. In Hsü, K. J., and Jenkins, H. C. (Eds.), Pelagic Sediments on Land and Under the Sea: Spec. Publs. Init. Ass. Sedim., 1:11-48.

Bonatti, E., Kolla, V., Moore, W. S., et al., 1979. Metallogenesis in marginal basins: Fe-rich basal deposits from the Philippine Sea. Mar. Geol., 32:21-37.

Dietrich, V., Emmermann, R., Oberhansli, R., et al., 1978. Geochemistry of the basaltic and gabbroic rocks from the West Mariana Basin and the Mariana Trench. Earth Planet. Sci. Lett., 39:127-144.
Ewart, A., and Bryan, W., 1972. Petrography and geochemistry of the igneous rocks from Eva, Tonga Islands. Geol. Soc. Am. Bull., 83:3281-3298.

Fischer, A. G., Heezen, B. C., et al., 1971. Init. Repts. DSDP, 6: Washington (U.S. Govt. Printing Office).

Foster, J., 1972. Paleomagnetism of deep sea sediments [Ph.D. thesis]. Columbia University, New York, N.Y.

Hart, S. R., Glassley, W., and Karig, D., 1972. Basalts and sea-floor spreading behind the Mariana Island arc. Earth Planet. Sci. Lett. 15:12-18.

Hawkins, J. W., 1977. Petrologic and chemical characteristics of marginal basin basalts. In Talwani, M., and Pitman, W. C., III (Eds.), Island Arcs, Deep Sea Trenches, and Back-Arc Basins: Washington (Am. Geophys. Union), pp. 355-365.

International Working Group on the IGCP Project "Ophiolites," 1977. Initial report of the geological study of oceanic crust of the Philippine Sea floor. In Bogdanov, N. (Ed.), Bollettino del Grupo di Lavoro aulle Ofioliti Mediterranee (Vol. 2): Bologna (Estratto da Ofioliti), 137-168.

Karig, D. E., 1975. Basin genesis in the Philippine Sea. In Karig, D. E., Ingle, J. C., Jr., et al., Init. Repts. DSDP, 31: Washington (U.S. Govt. Printing Office), 857-879.

Karig, D. E., Ingle, J. C., Jr., et al., 1975. Init. Repts. DSDP, 31: Washington (U.S. Govt. Printing Office).

Klein, G. deV., Kobayashi, K., et al., in press. Init. Repts. DSDP, 58: Washington (U.S. Govt. Printing Office).

LaBrecque, J. L., Kent, D. V., and Cande, S. C., 1977. Revised magnetic polarity time scale for Late Cretaceous and Cenozoic time. Geology, 5:330-335.

Martini, E., 1971. Standard Tertiary and Quaternary calcareous nannoplankton zonation. Proc. Second Planktonic Conference, Rome, 1970, 2:739-785.

1976. Cretaceous to Recent calcareous nannoplankton from the central Pacific Ocean (DSDP Leg 33). In Schlanger, S. O., Jackson, E. D., et al., Init. Repts. DSDP, 33: Washington (U.S. Govt. Printing Office), 383-423.

Melson, W., and Thompson, G., 1971. Petrology of a transform fault zone and adjacent ridge segments. Phil. Trans. R. Soc., London. Ser. A., 268:423-442.

Mrozowski, D. L., and Hayes, D. E., 1979. The evolution of the Parece Vela Basin, Eastern Philipine Sea. Earth Planet. Sci. Lett., 46:49-67.

Murauchi, S., Den, N., Asano, S., et al., 1968. Crustal structure of the Philippine Sea. J. Geophys. Res., 73:3143-3171.

Nigrini, C. A., 1971. Radiolarian zones in the Quaternary of the equatorial Pacific Ocean. In Funnell, B. M., and Riedel, W. R. (Eds.), The Micropaleontology of Oceans: New York (Cambridge Univ. Press), pp. 443-461.

Sclater, J. G., 1972. Heat flow and elevation of the marginal basins of the Western Pacific. J. Geophys. Res., 77:5705-5719.

Shih, T.-C., in press. Magnetic lineations in the Shikoku Basin. In, Klein, G. deV., Kobayashi, K., et al., Init. Repts. DSDP, 58: Washington (U.S. Govt. Printing Office).

Ujiie, H., 1975. Planktonic foraminiferal biostratigraphy in the Western Philippine Sea, Leg 31 of DSDP. In Karig, D. E., Ingle, J. C., Jr., et al., Init. Repts. DSDP, 31: Washington (U.S. Govt. Printing Office), 677-691.

Watts, A. G., and Weissel, J. K., 1975. Tectonic history of the Shikoku marginal basin. Earth Planet. Sci. Lett., 25:239-250. 

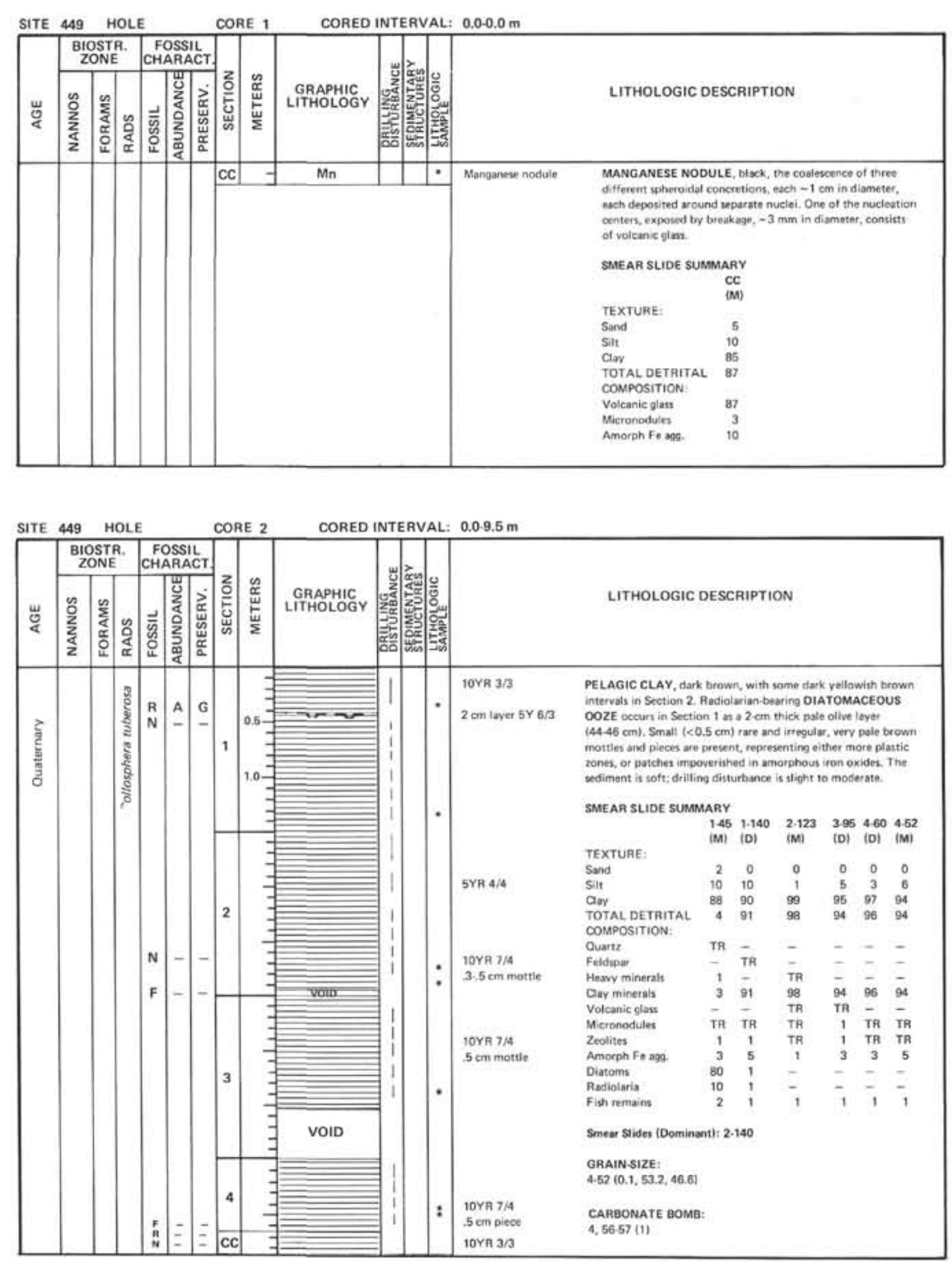

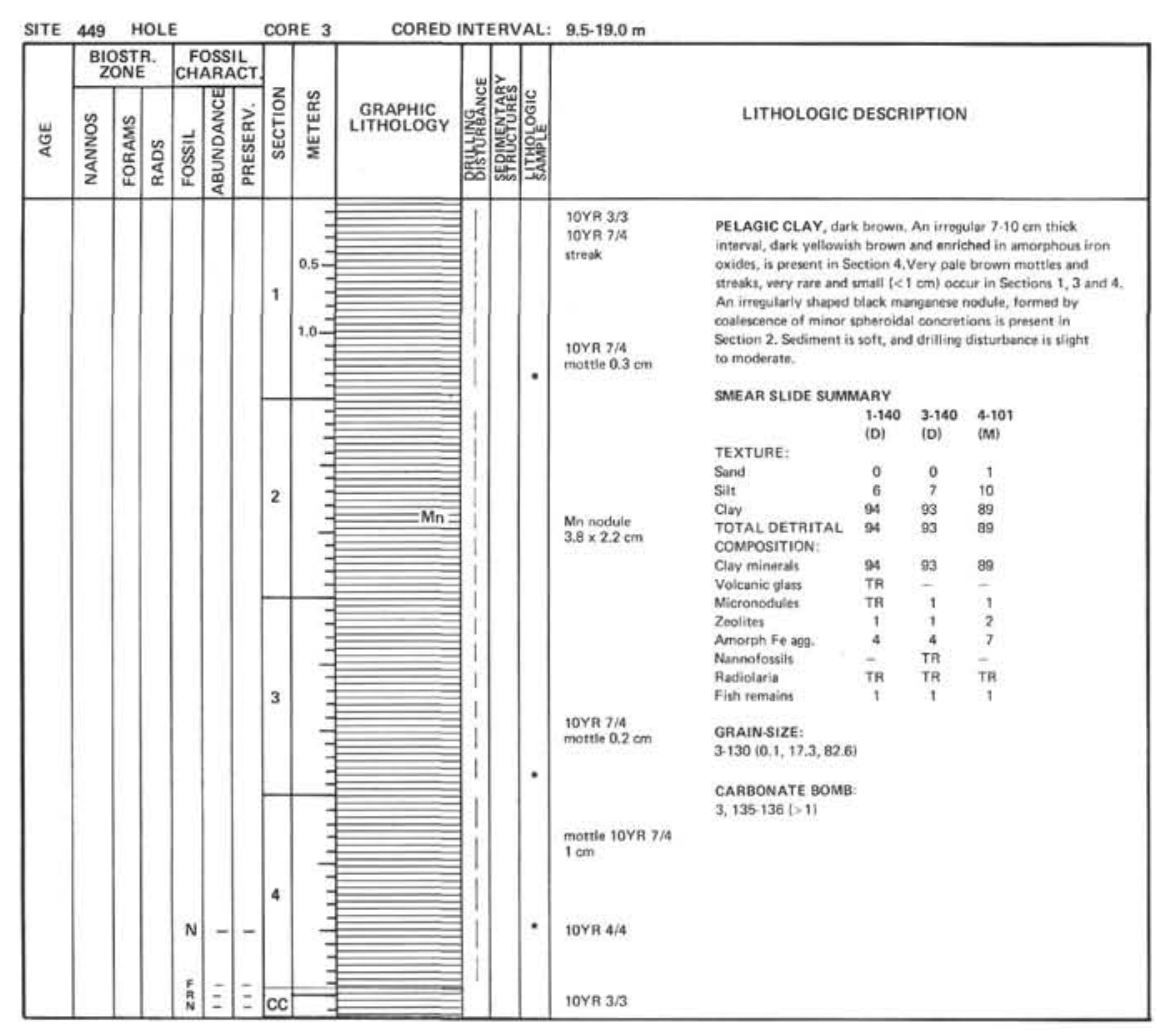



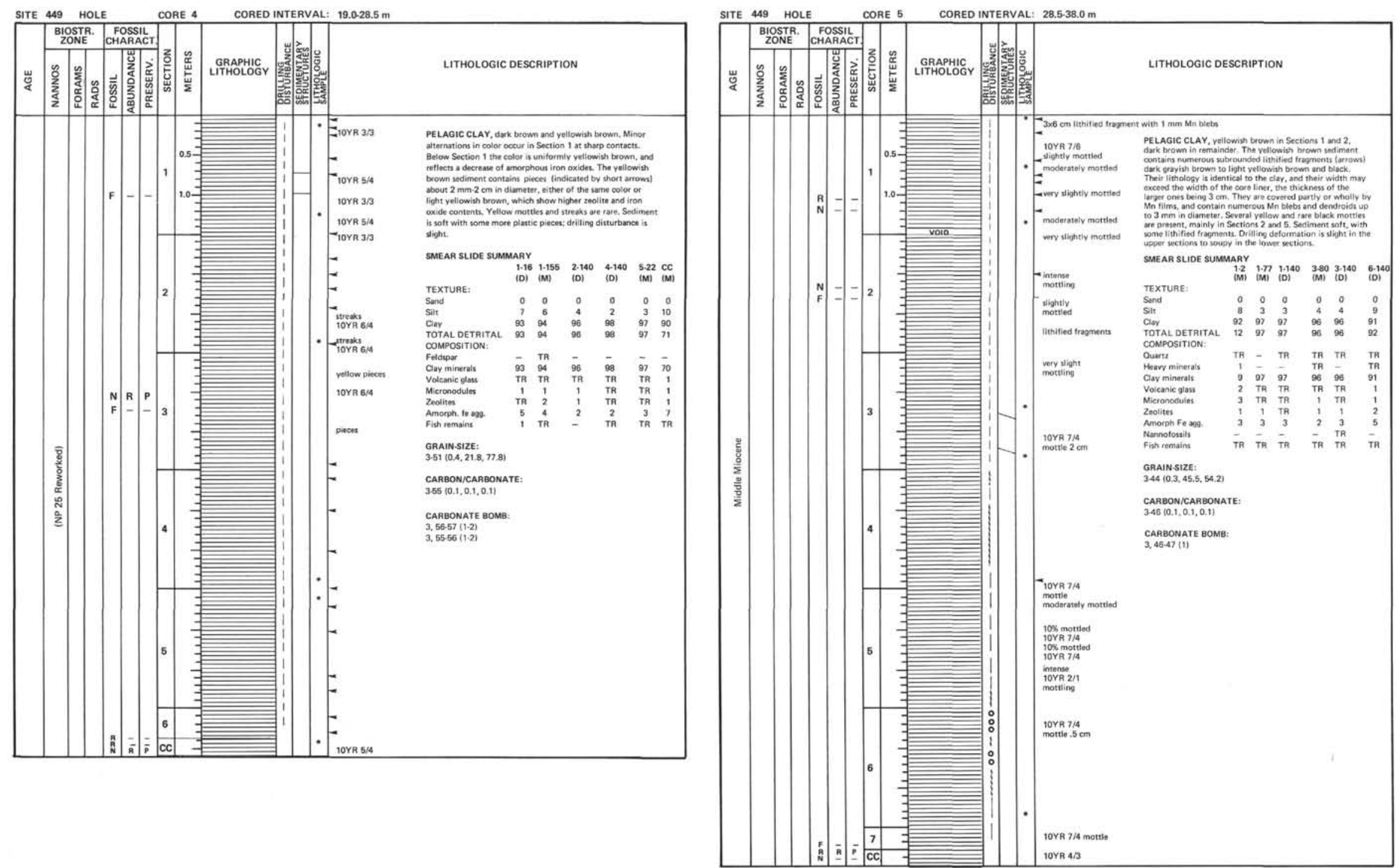


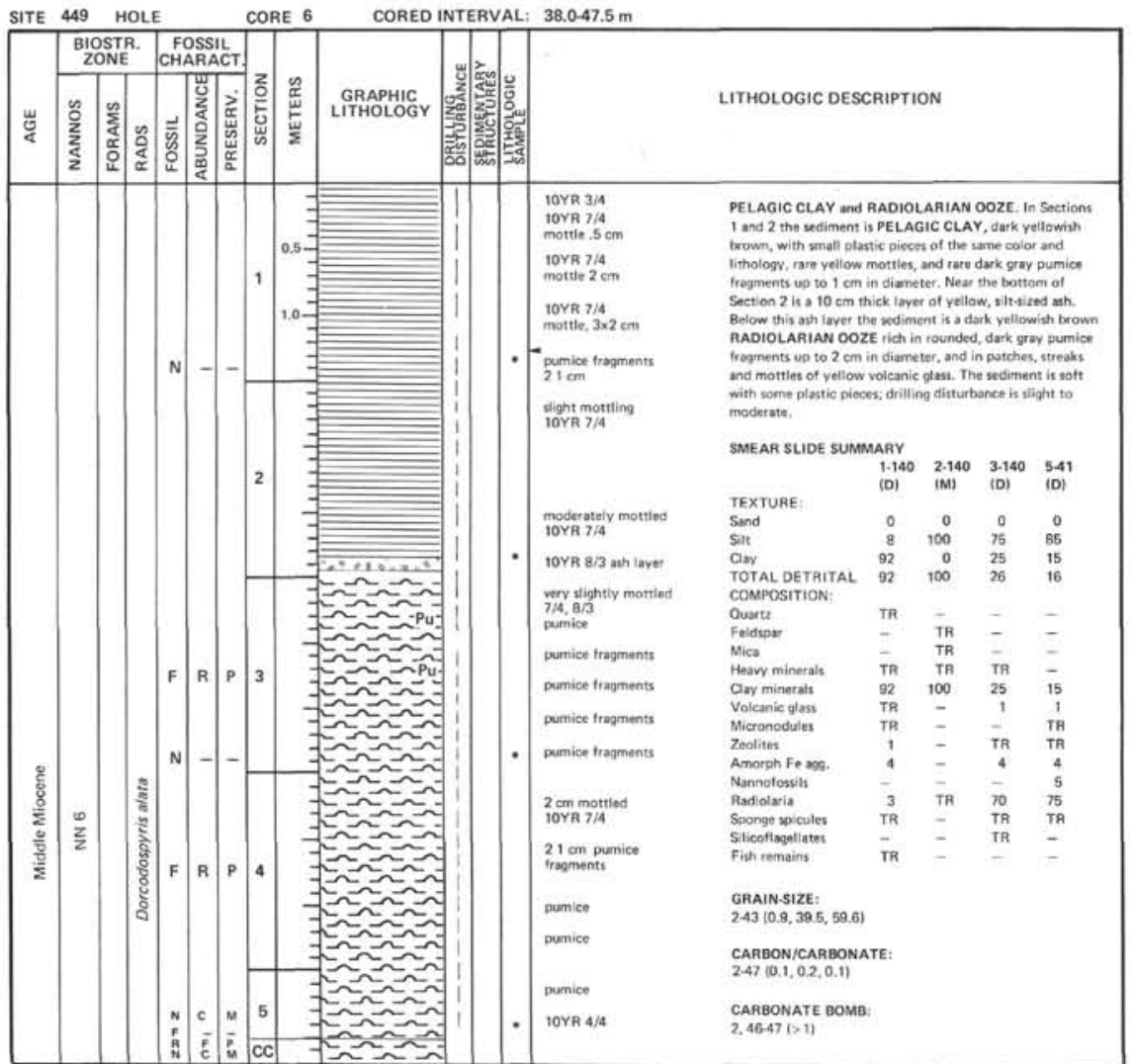

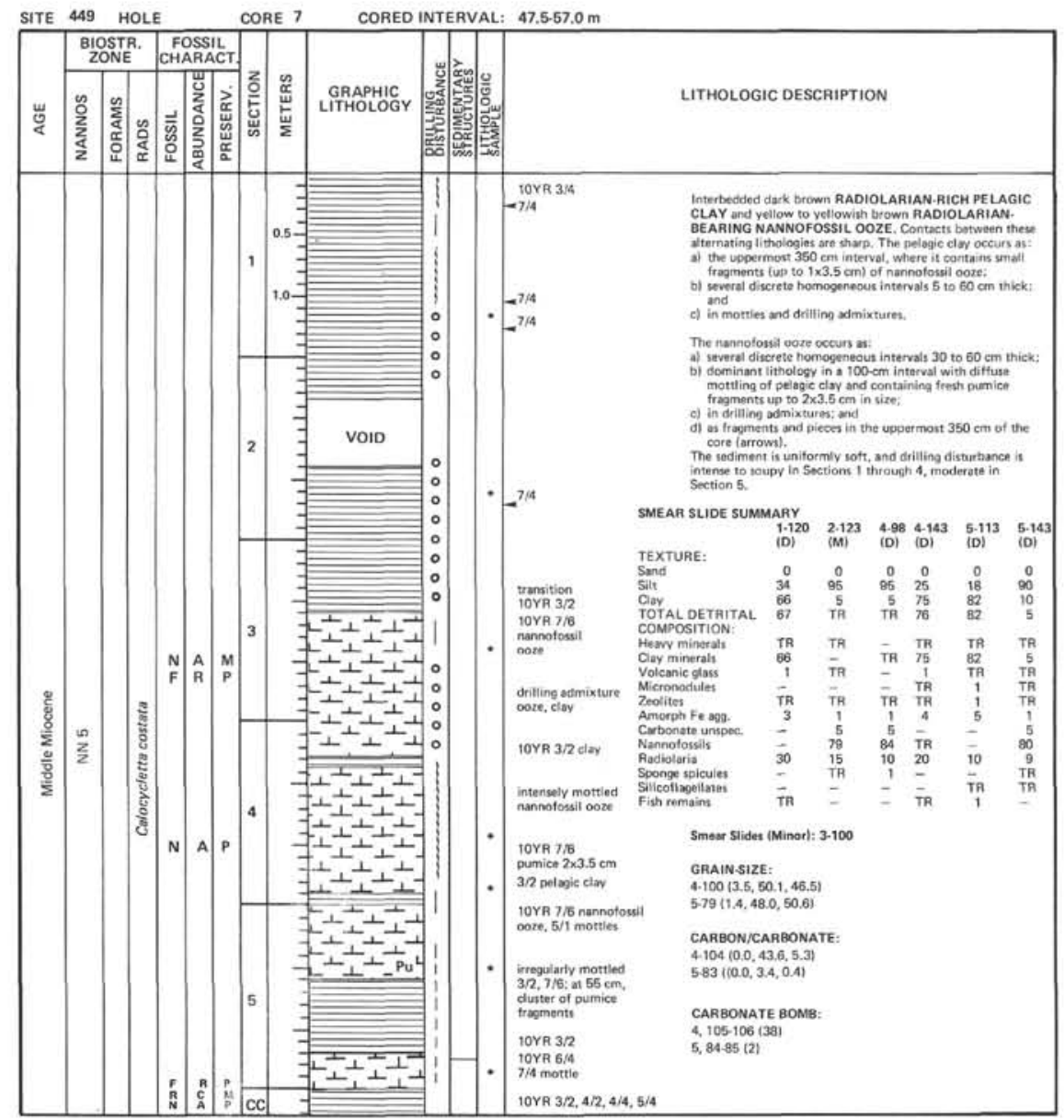



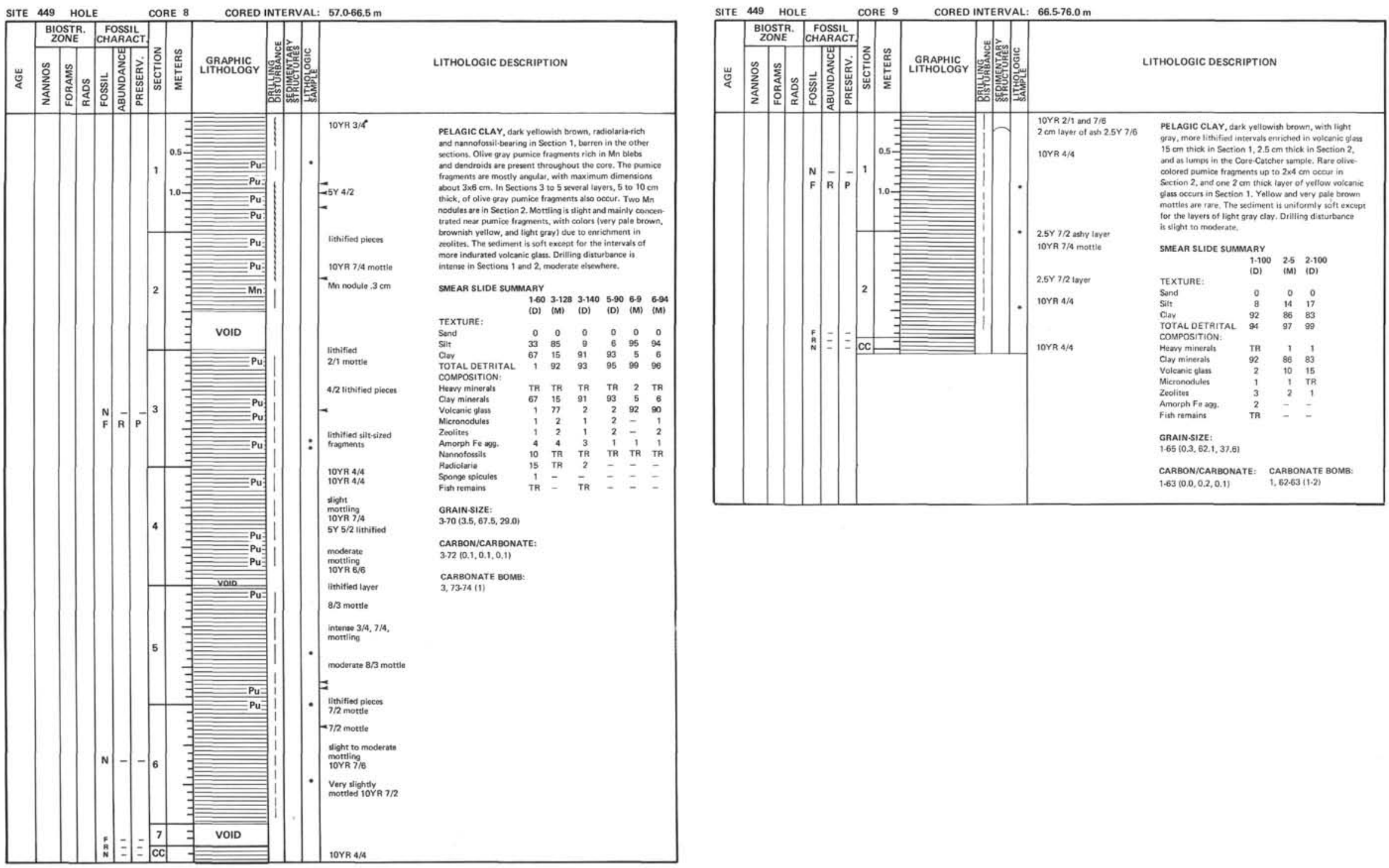


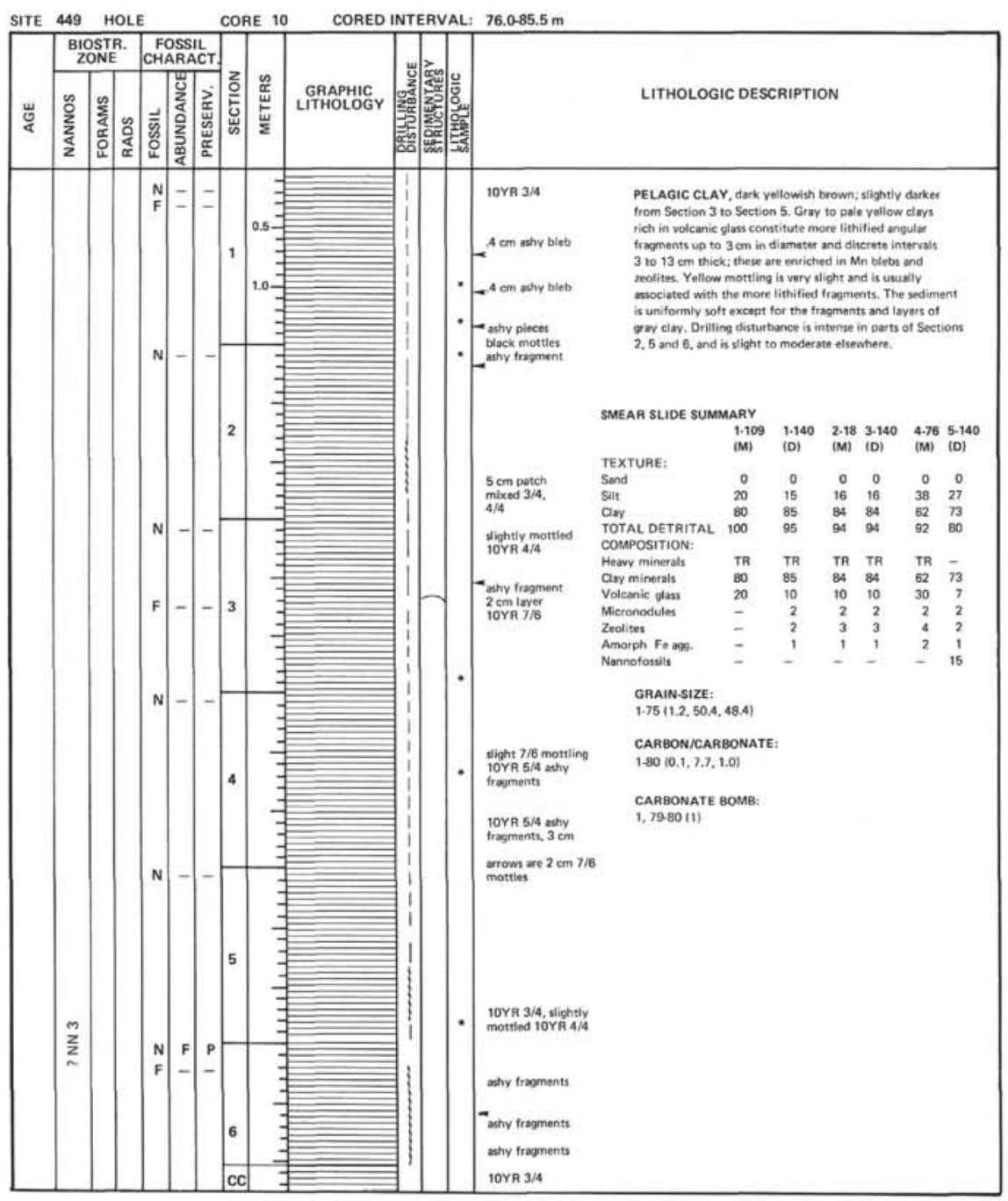

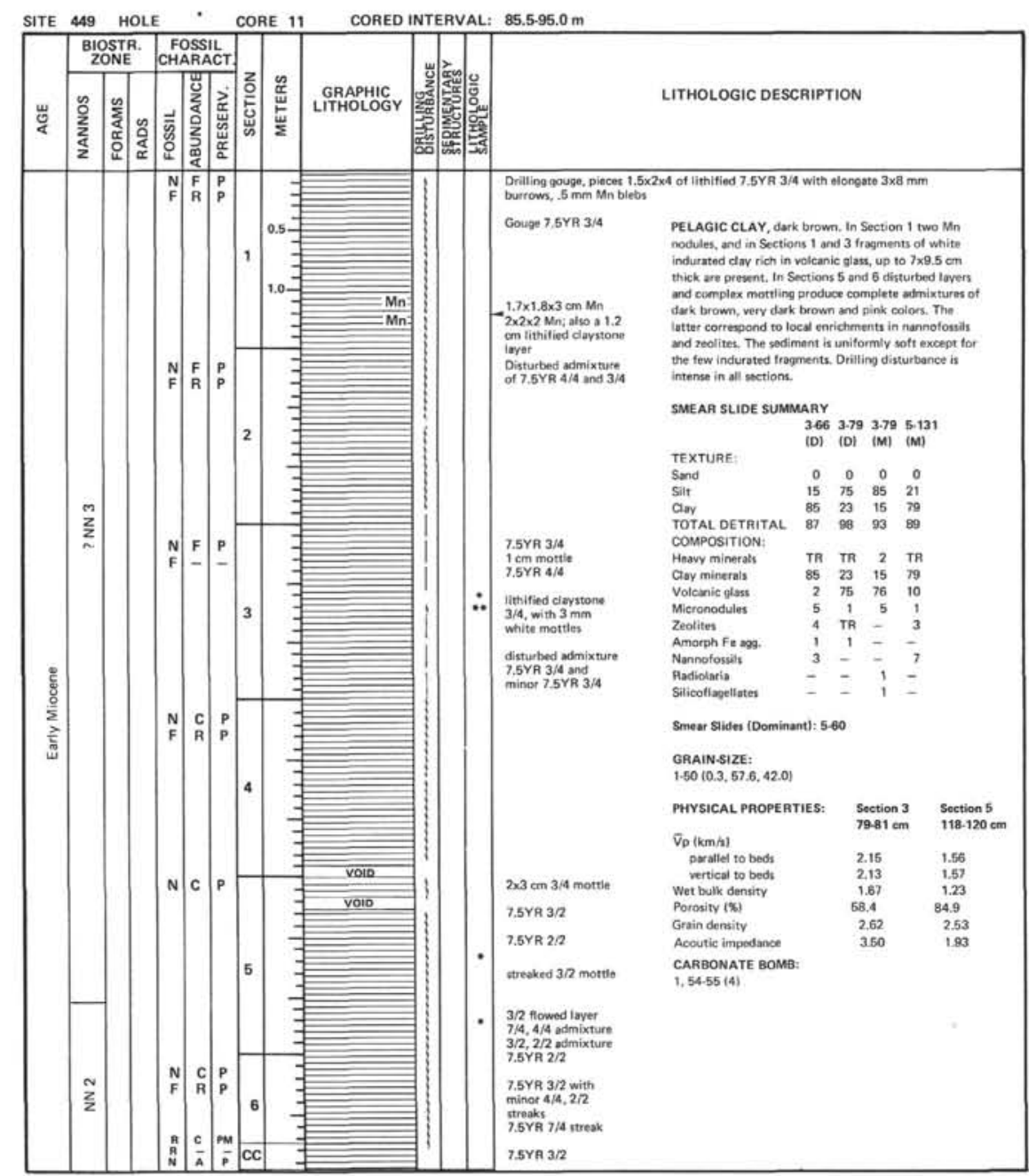




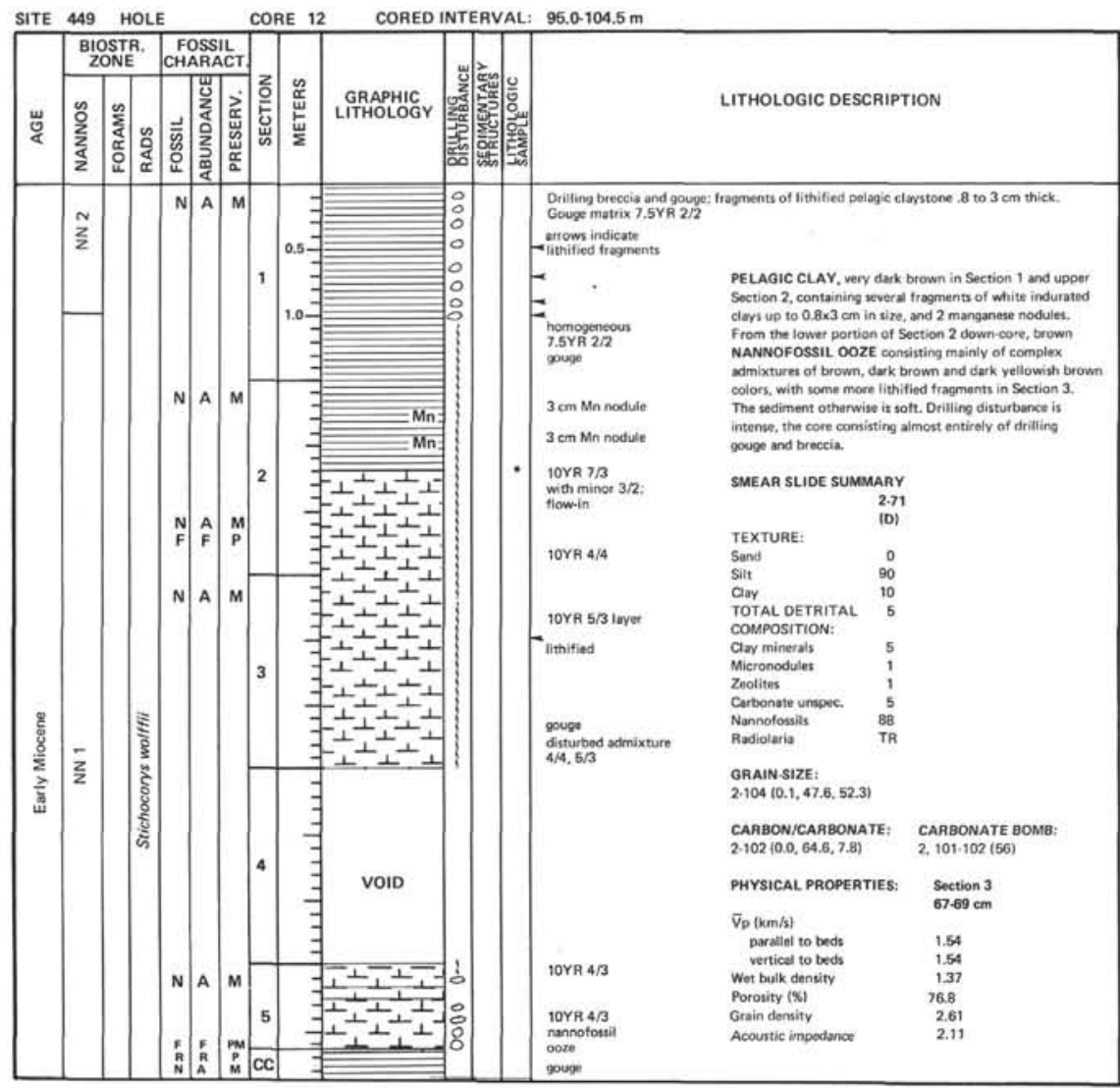

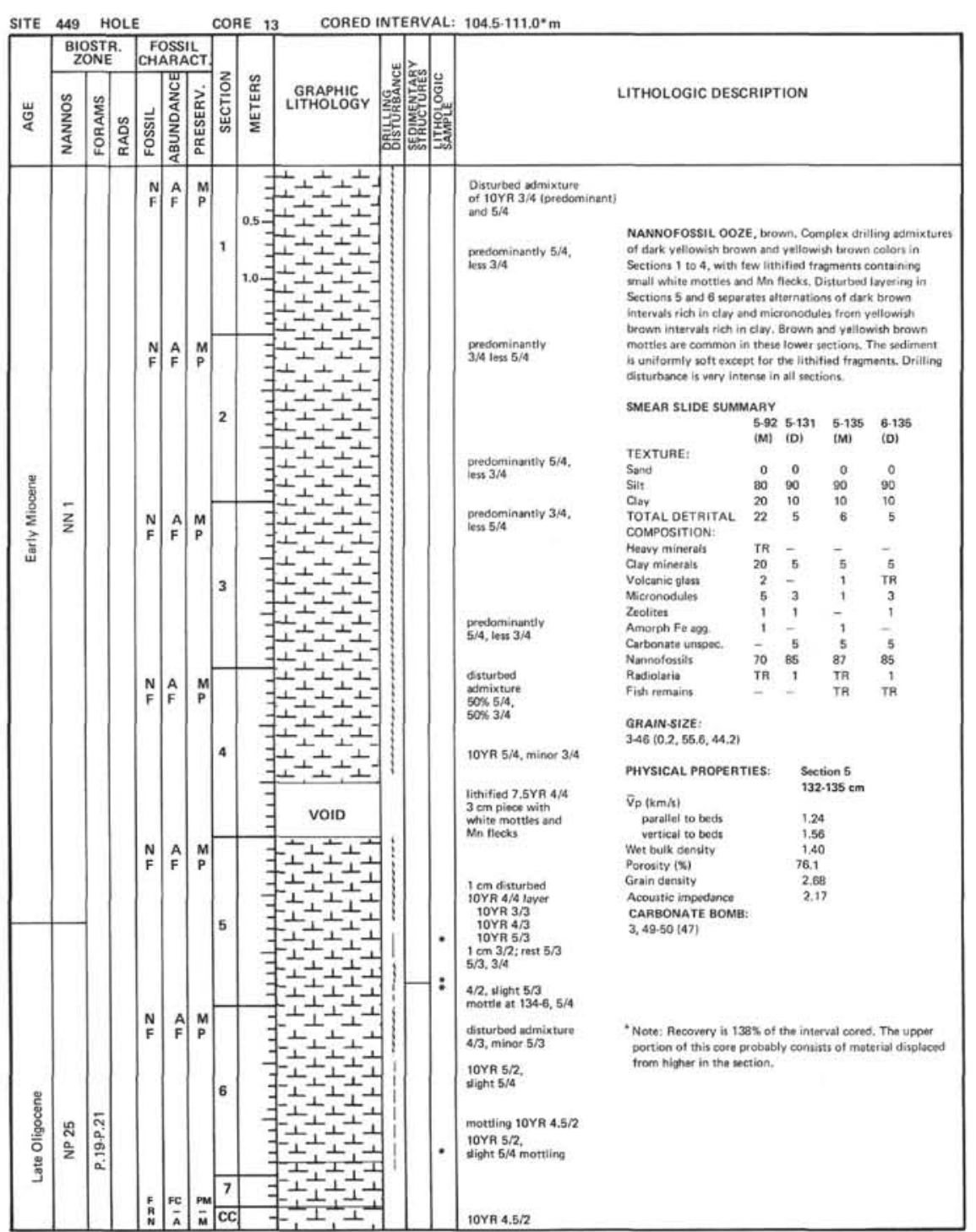



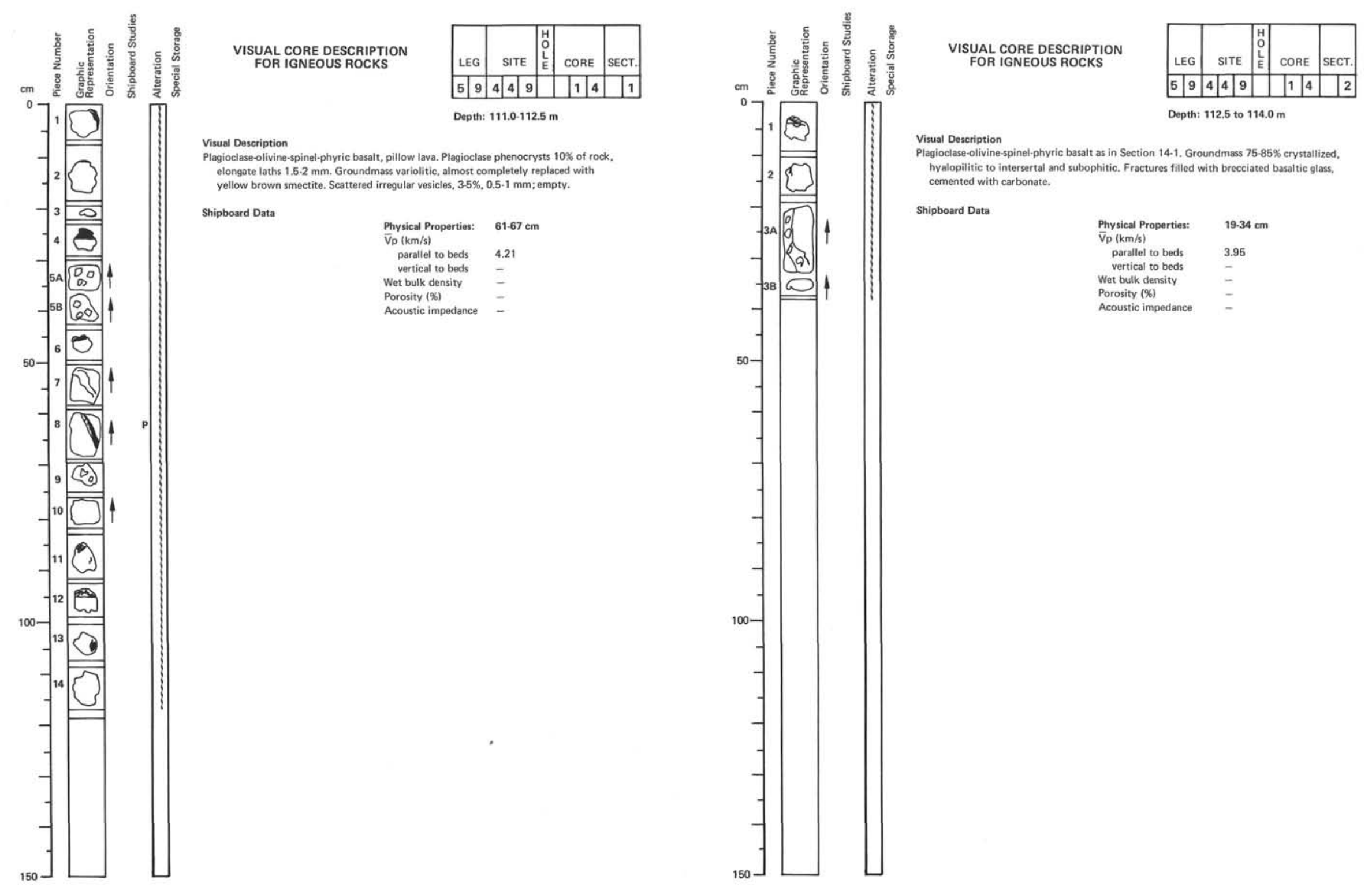

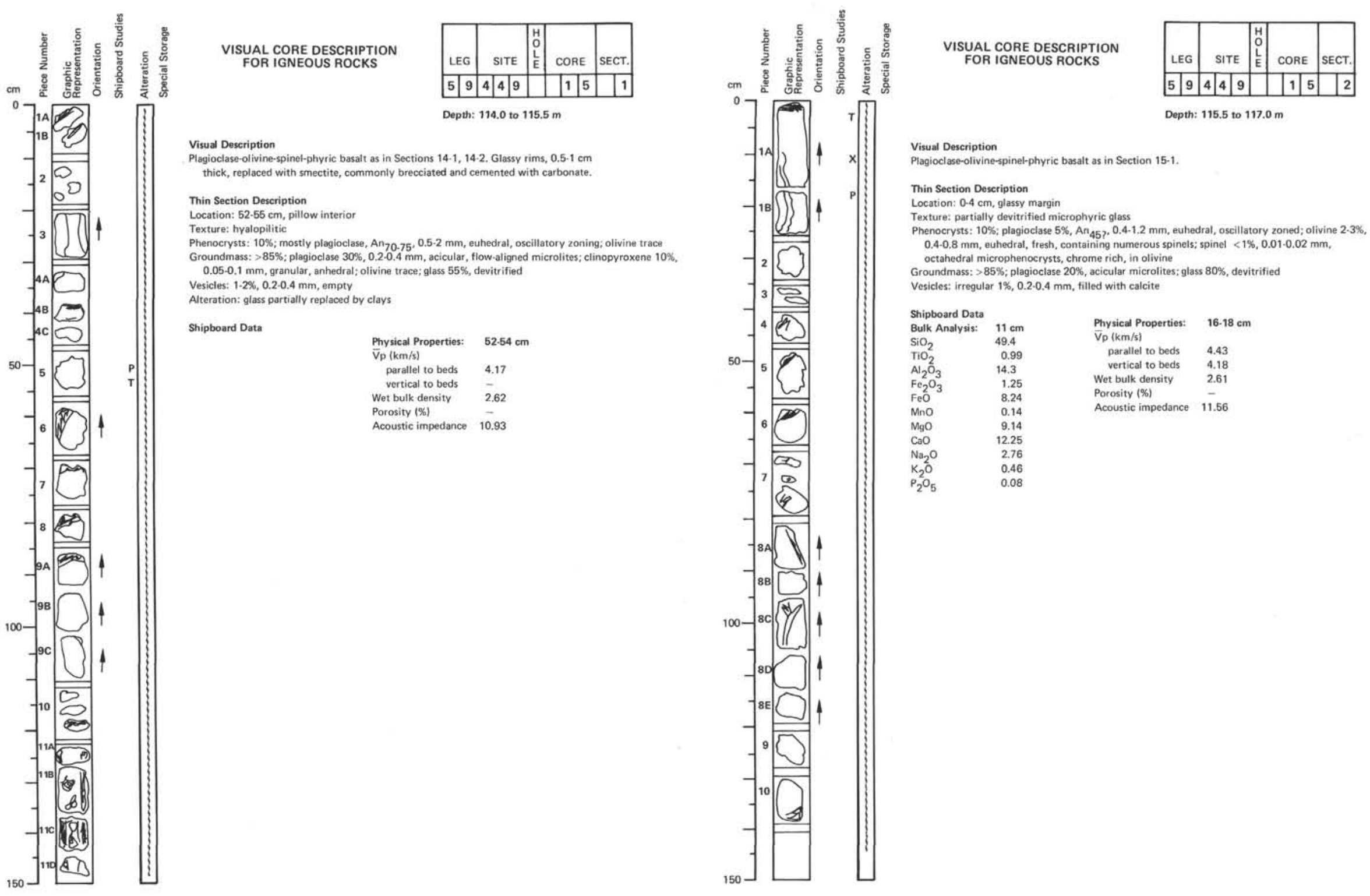

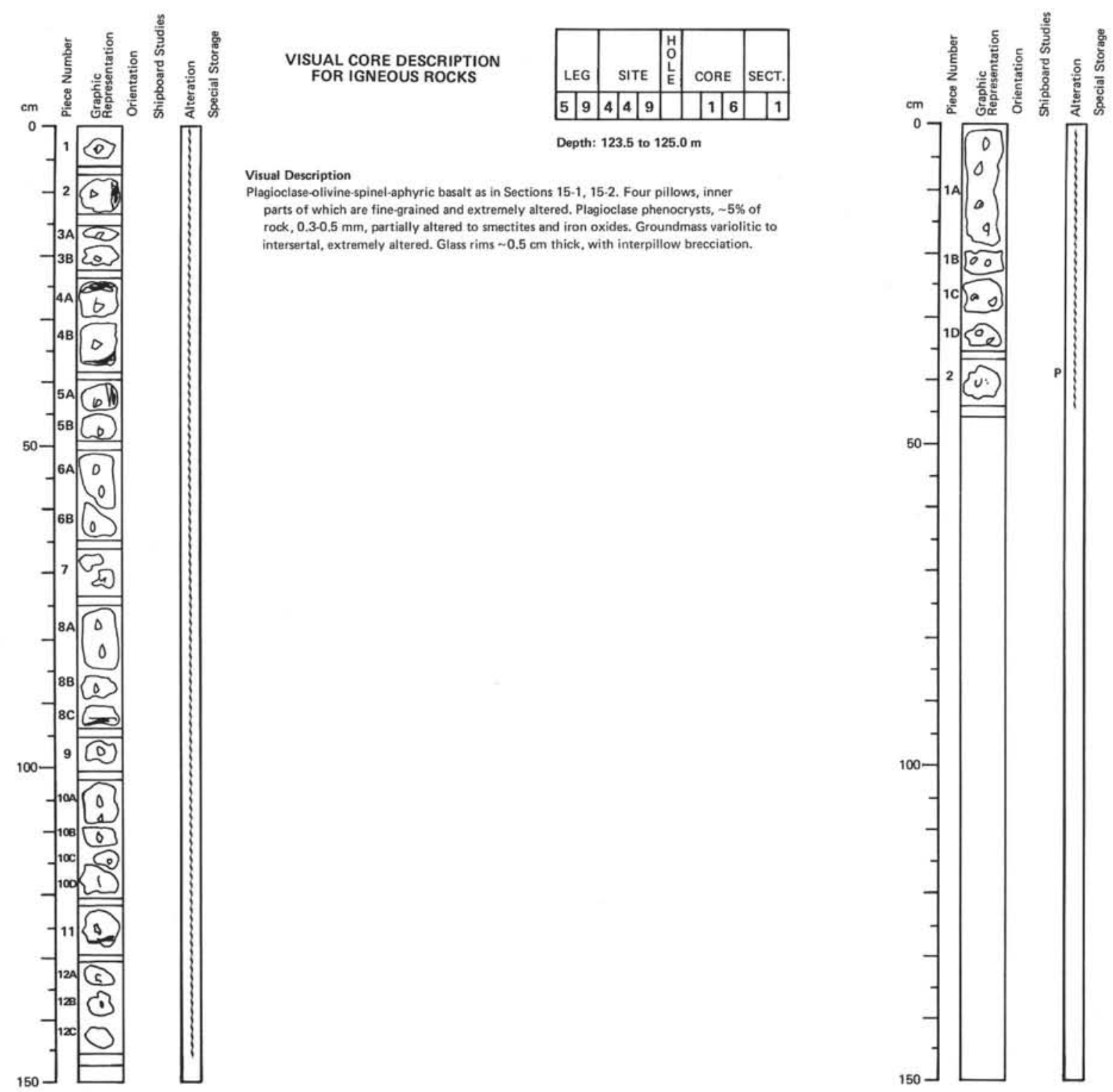
VISUAL CORE DESCRIPTION FOR IGNEOUS ROCKS

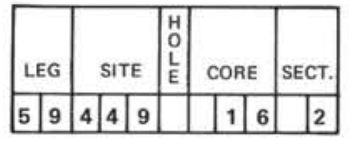

Visual Description

Plagioclase-olivine-spinel-phyric basalt as in Section 16-1.

Shipboard Data

Physical Properties: $\quad 38-40 \mathrm{~cm}$

parallet

parallel to beds 3.97
vertical to beds

Wet bulk density $\quad 2.53$

Porosity (\%) 


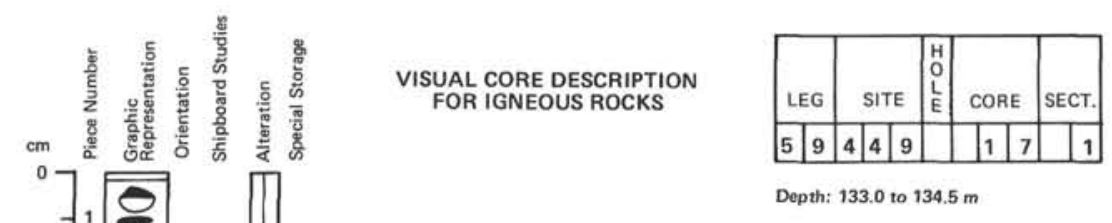

Visual Description and bottom of core, coarse-grained in central part of core.

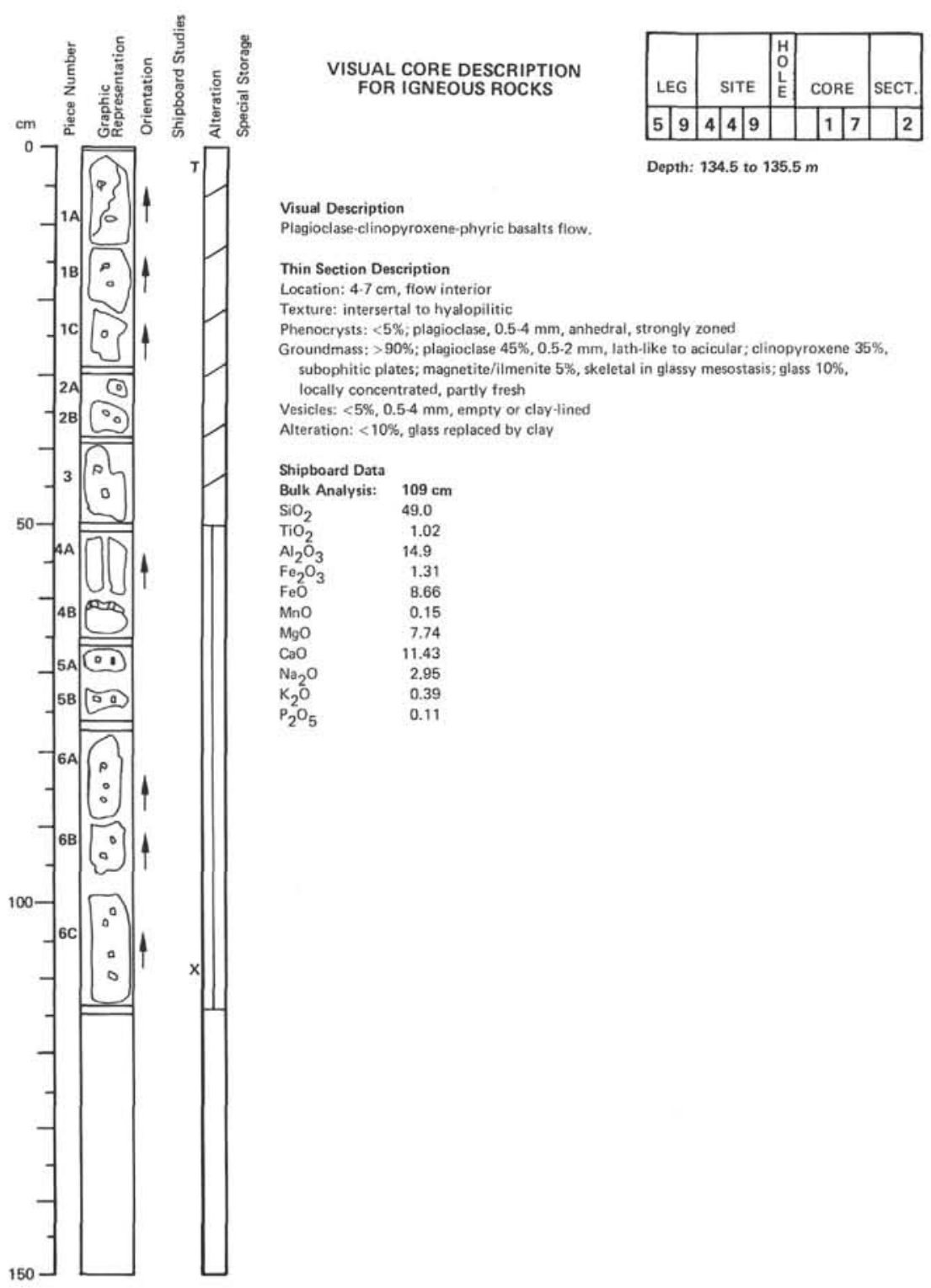




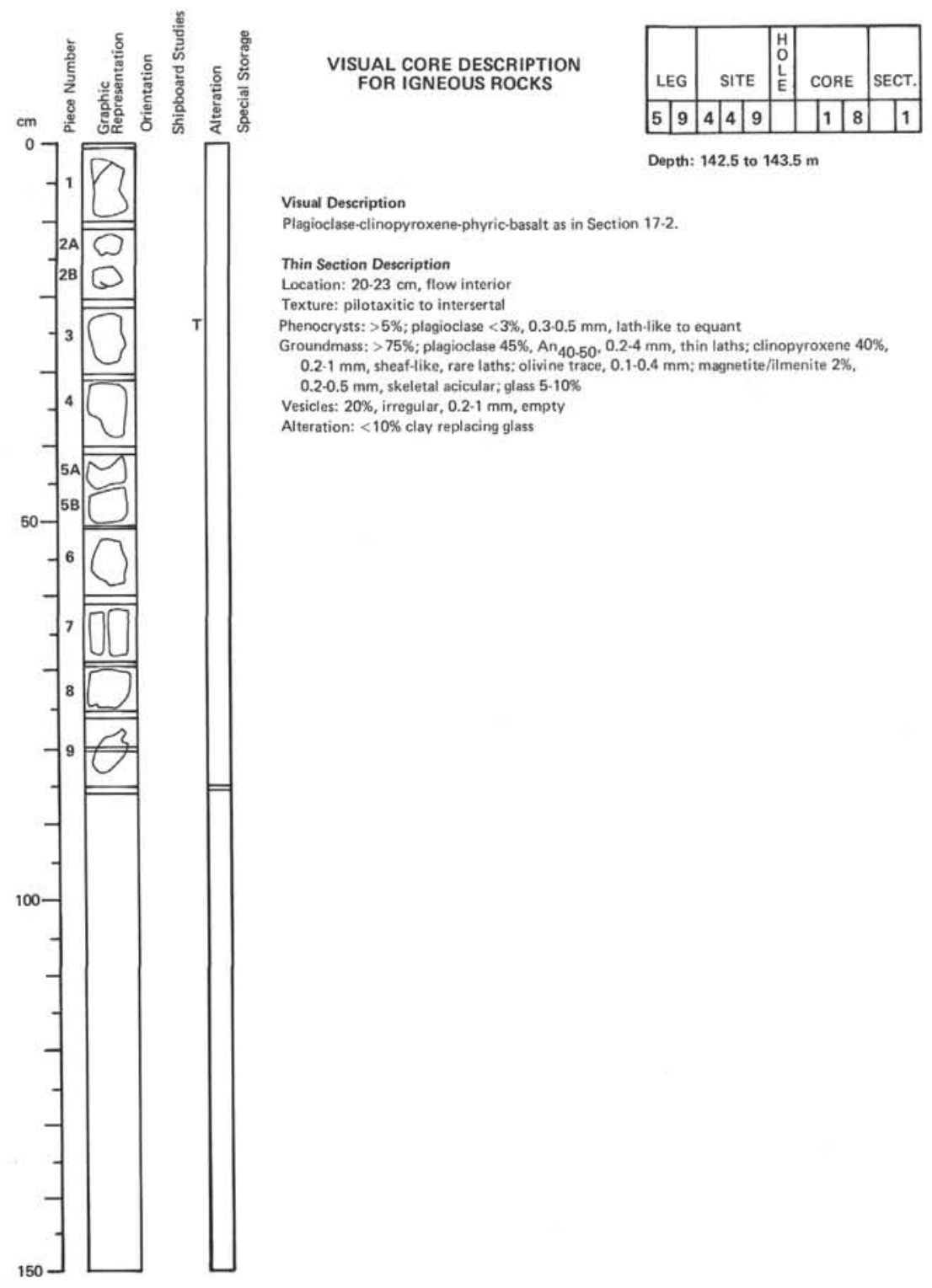


Hole 449

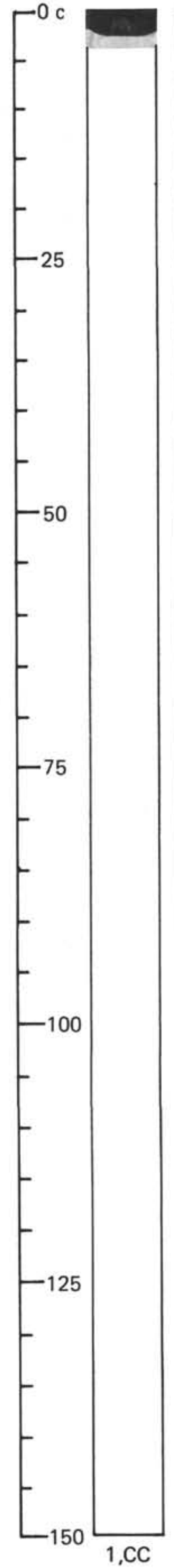

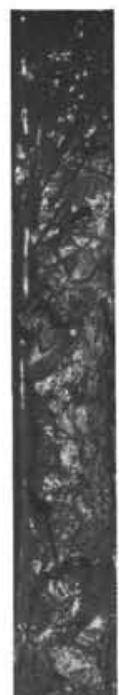
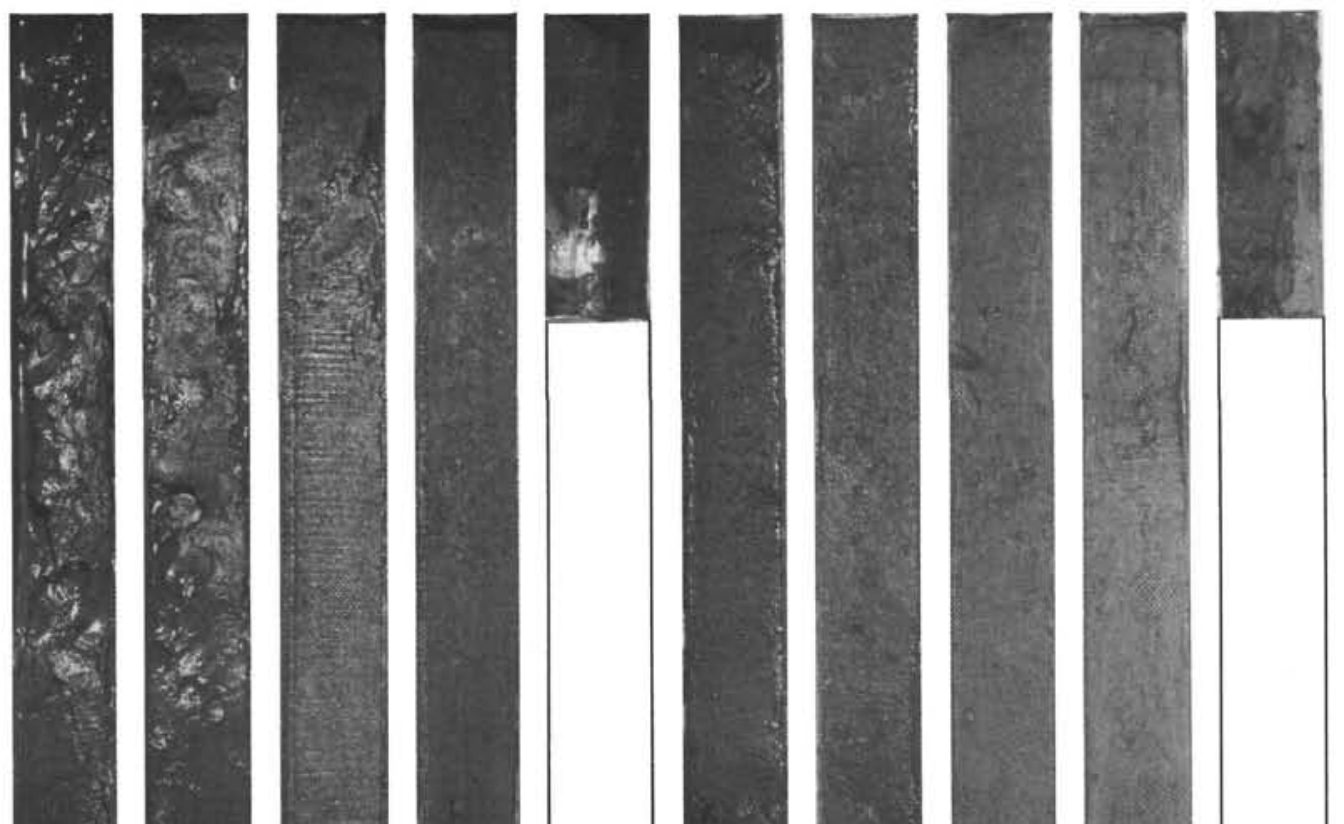
of:
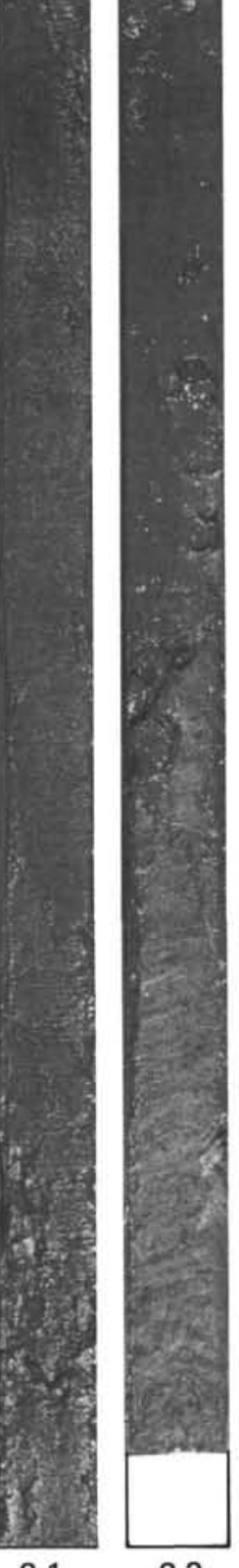

2-2

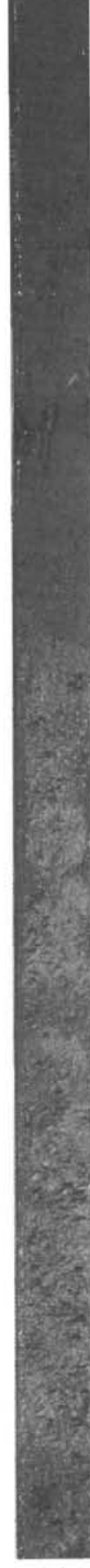


Hole 449

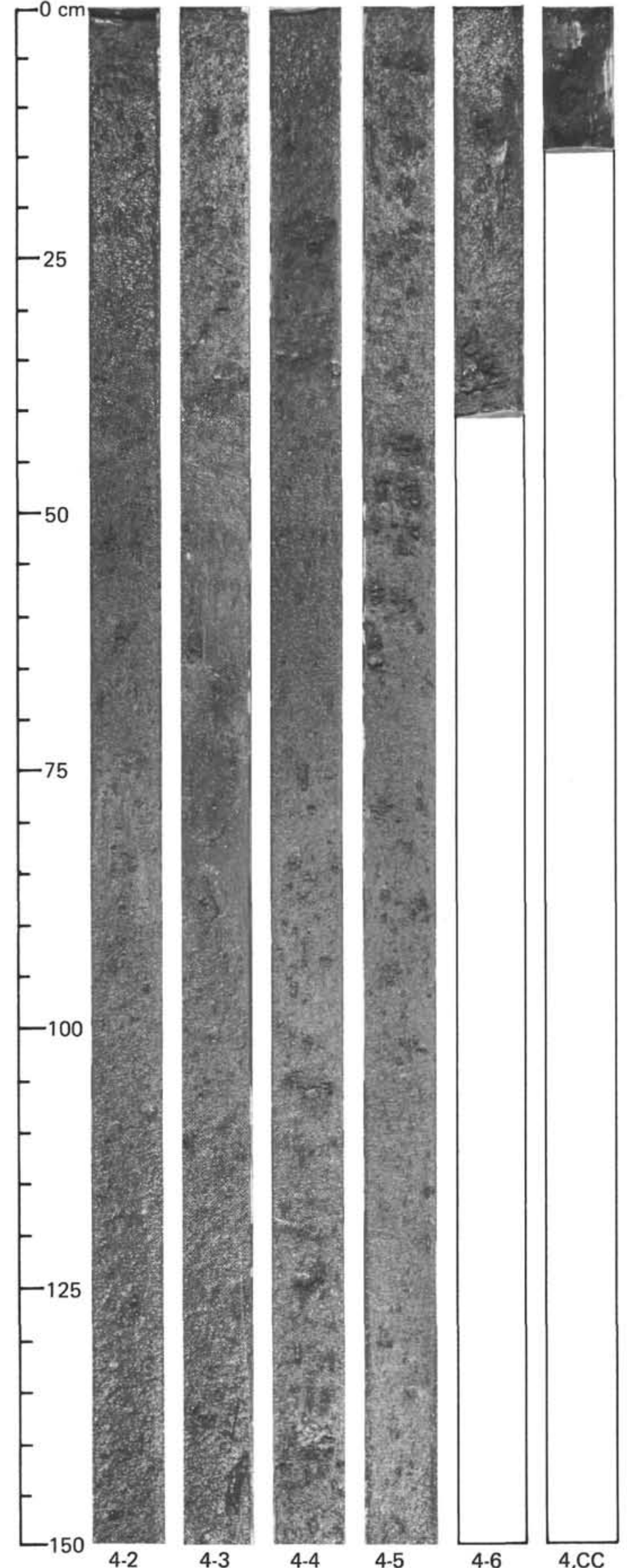

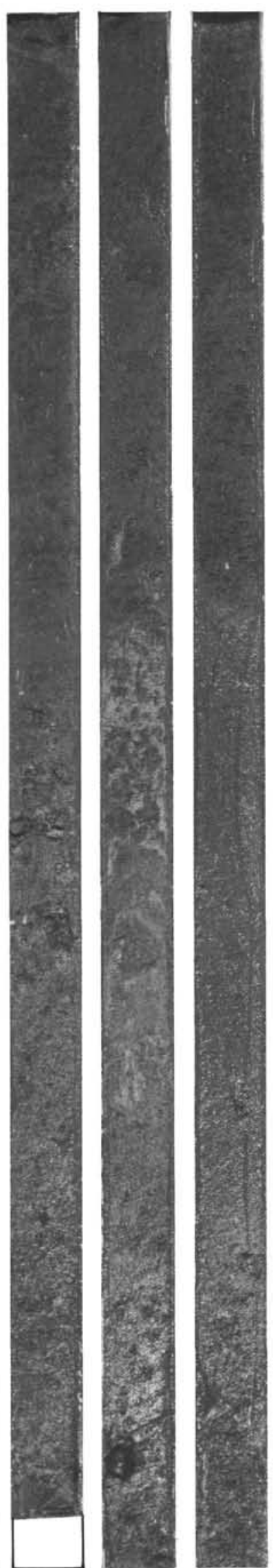

5-2

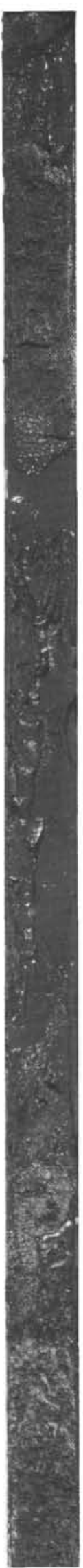

5-4

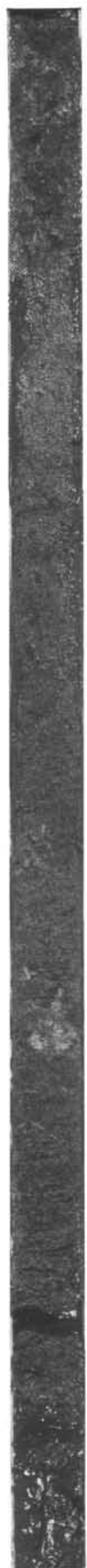

5-5

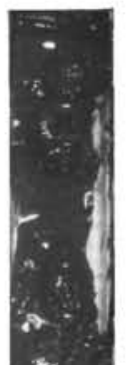

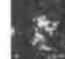

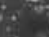
is $\frac{1}{4}$<smiles>c1ccc2ccccc2c1</smiles>
$x=2$ $4:$ (a) 75 करति

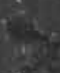
Es:

हैi.

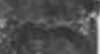
3 sit. atis cos $\varepsilon$
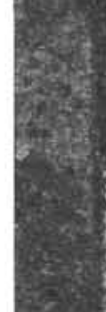

5-6 
Hole 449

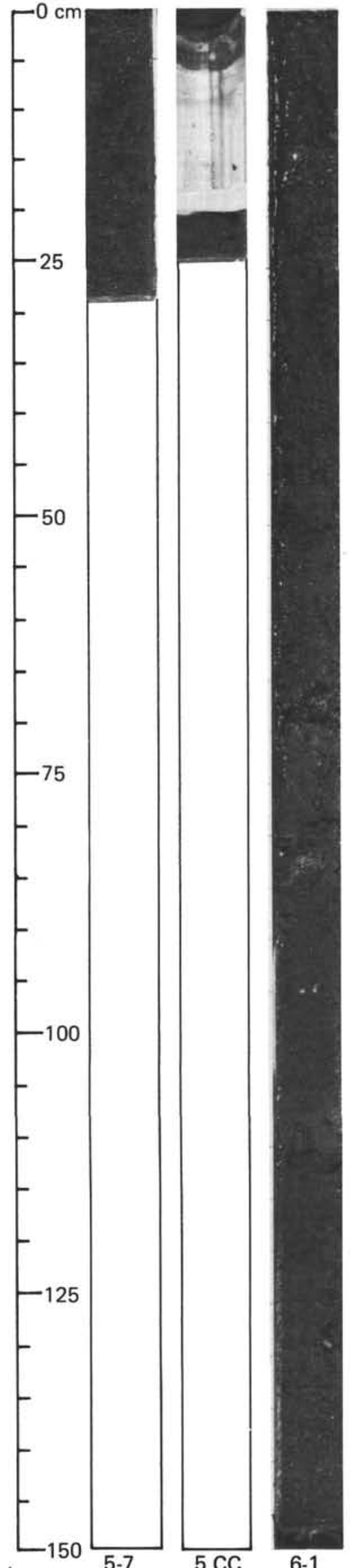

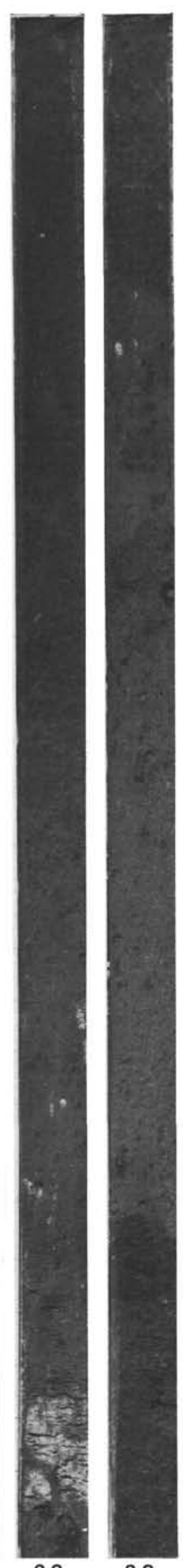

6-2
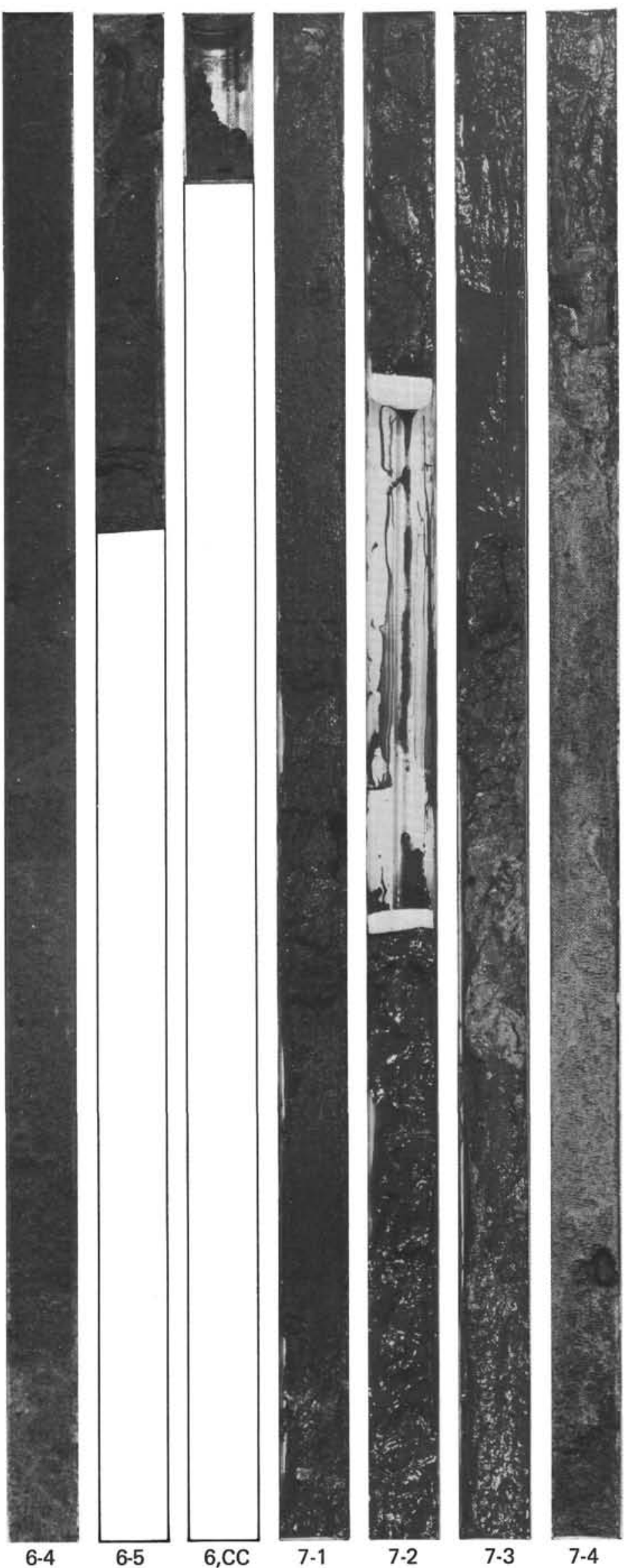
Hole 449

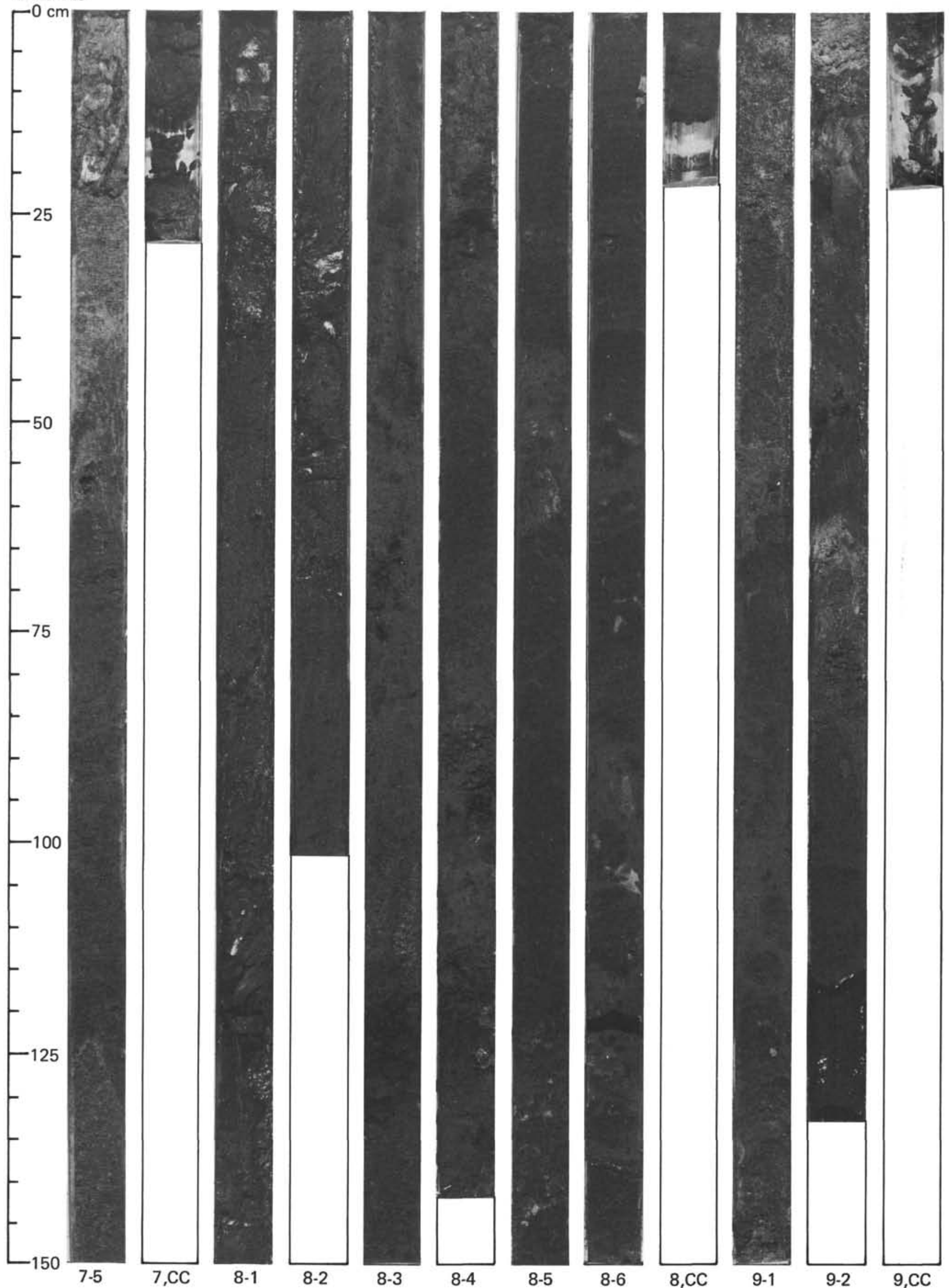




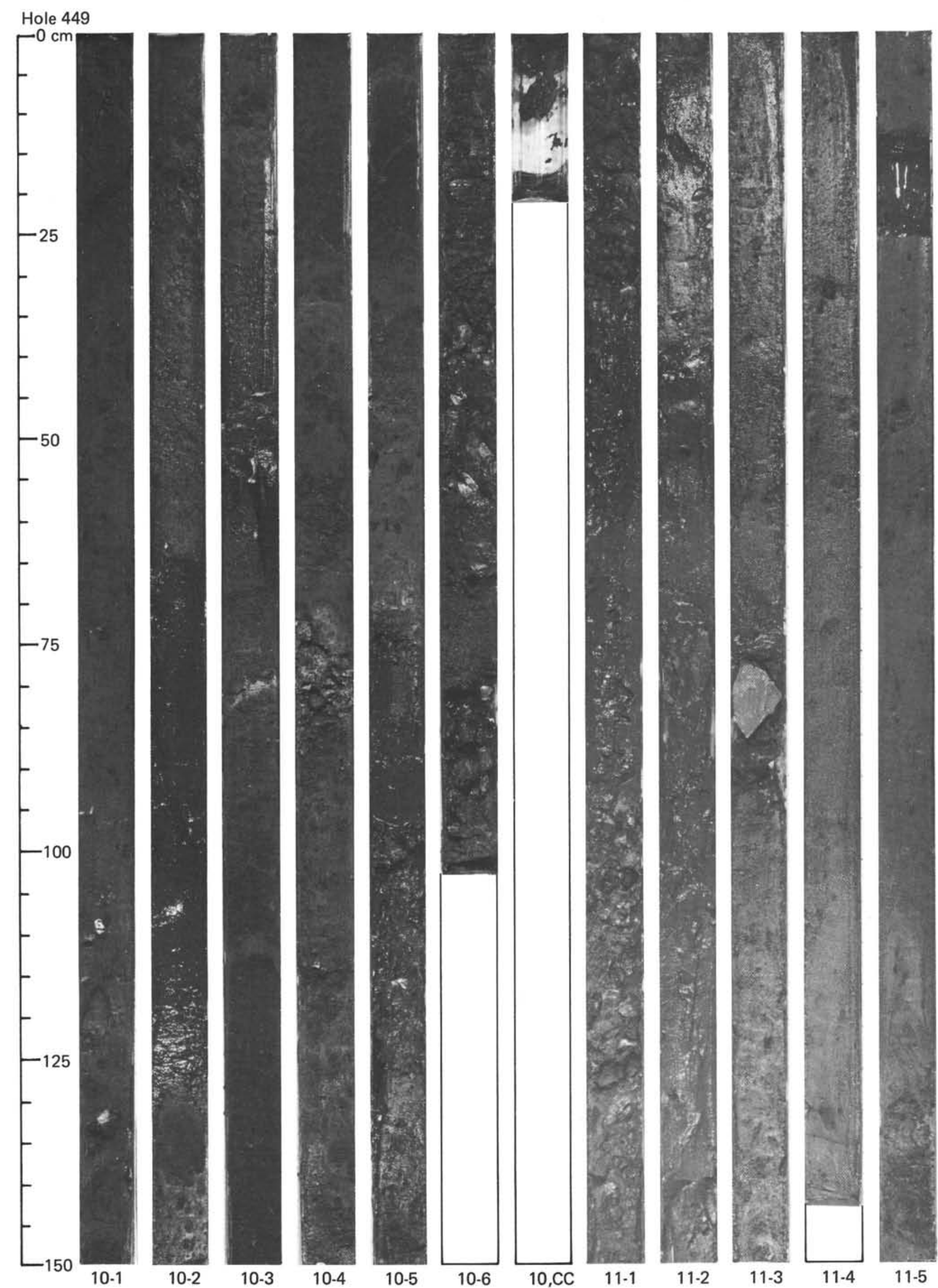




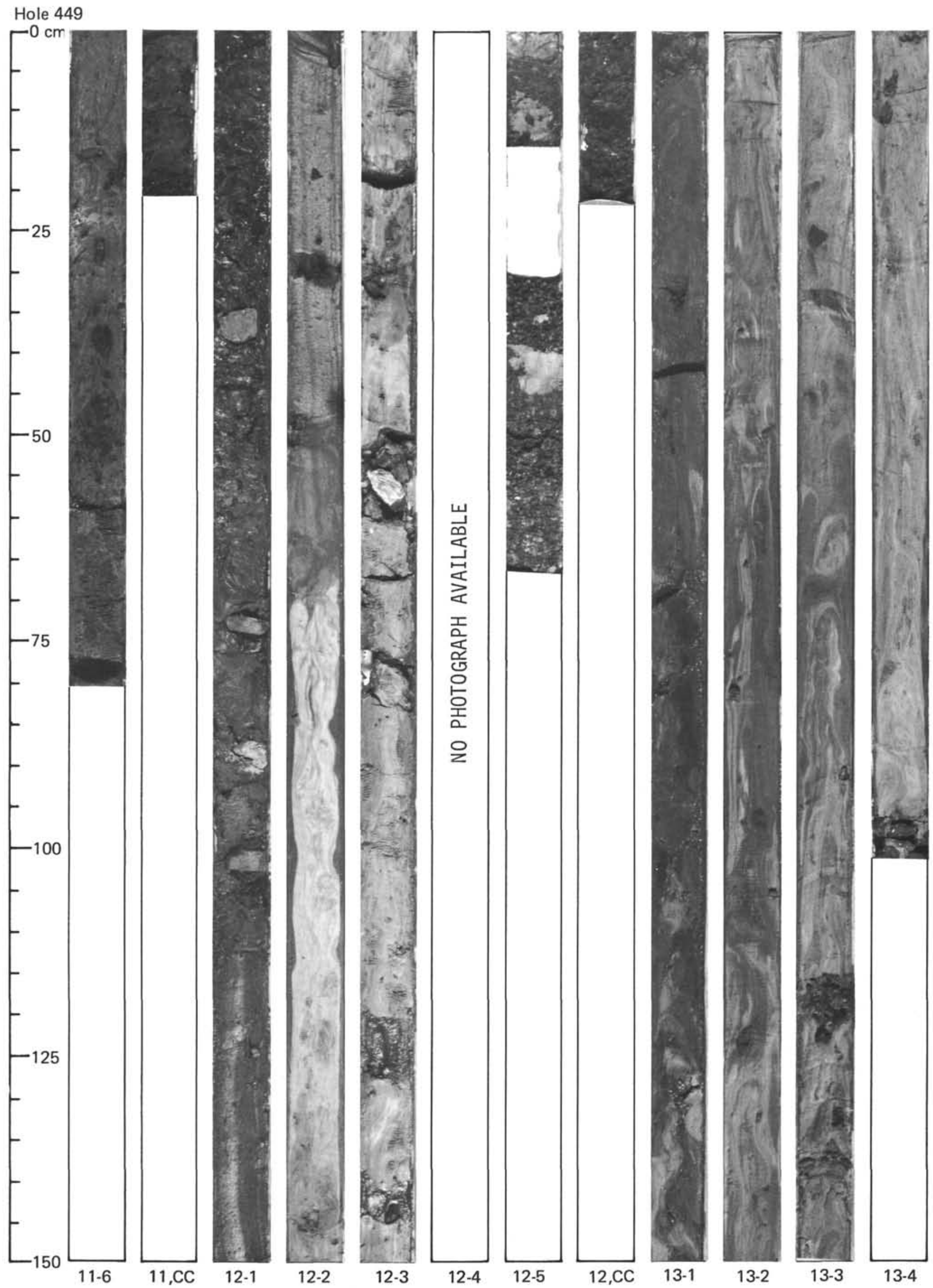


Hole 449 (No photograph available for $14-2$ to 14-6)

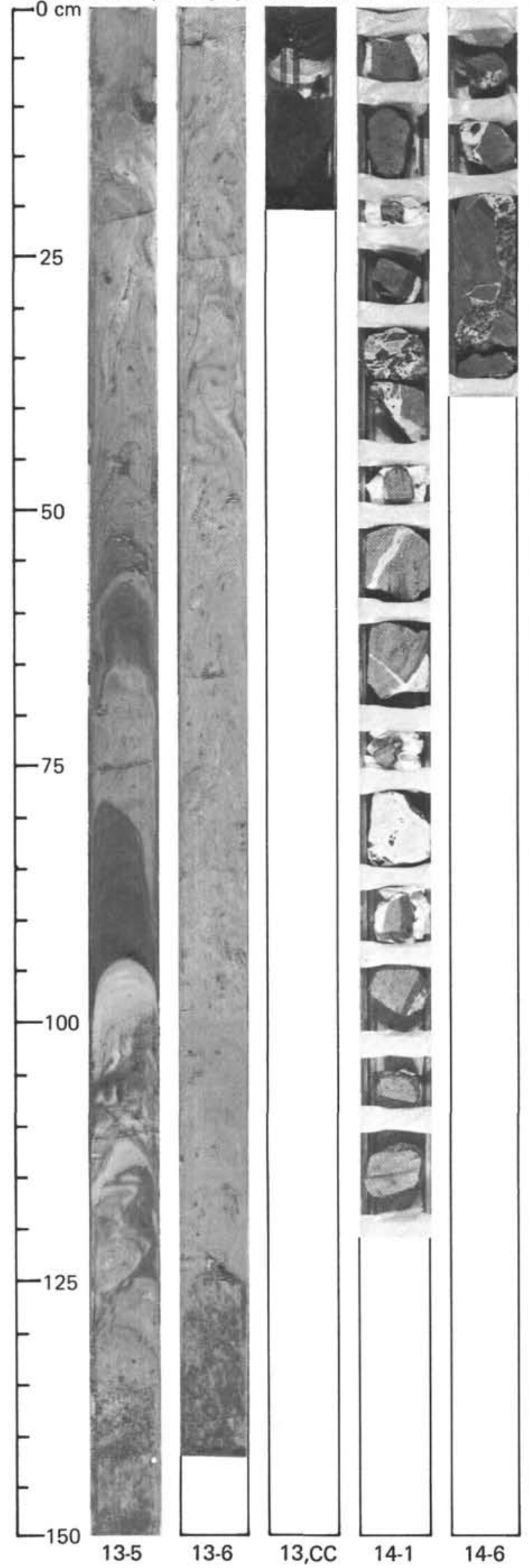

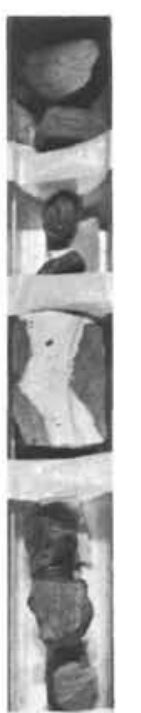
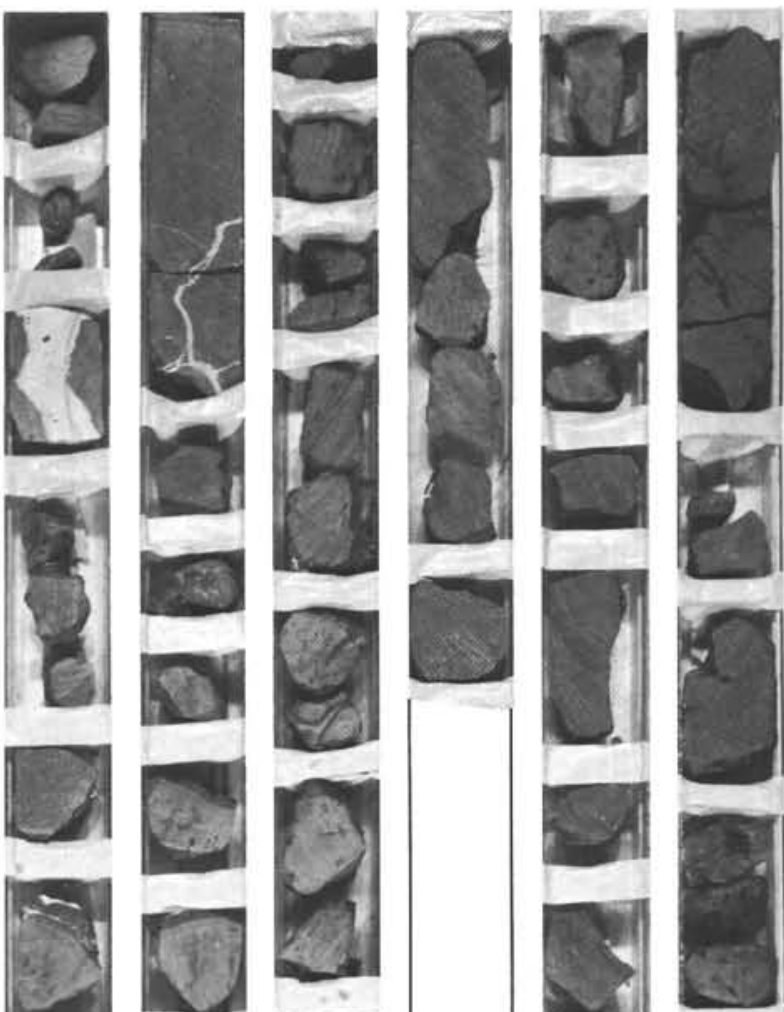

res
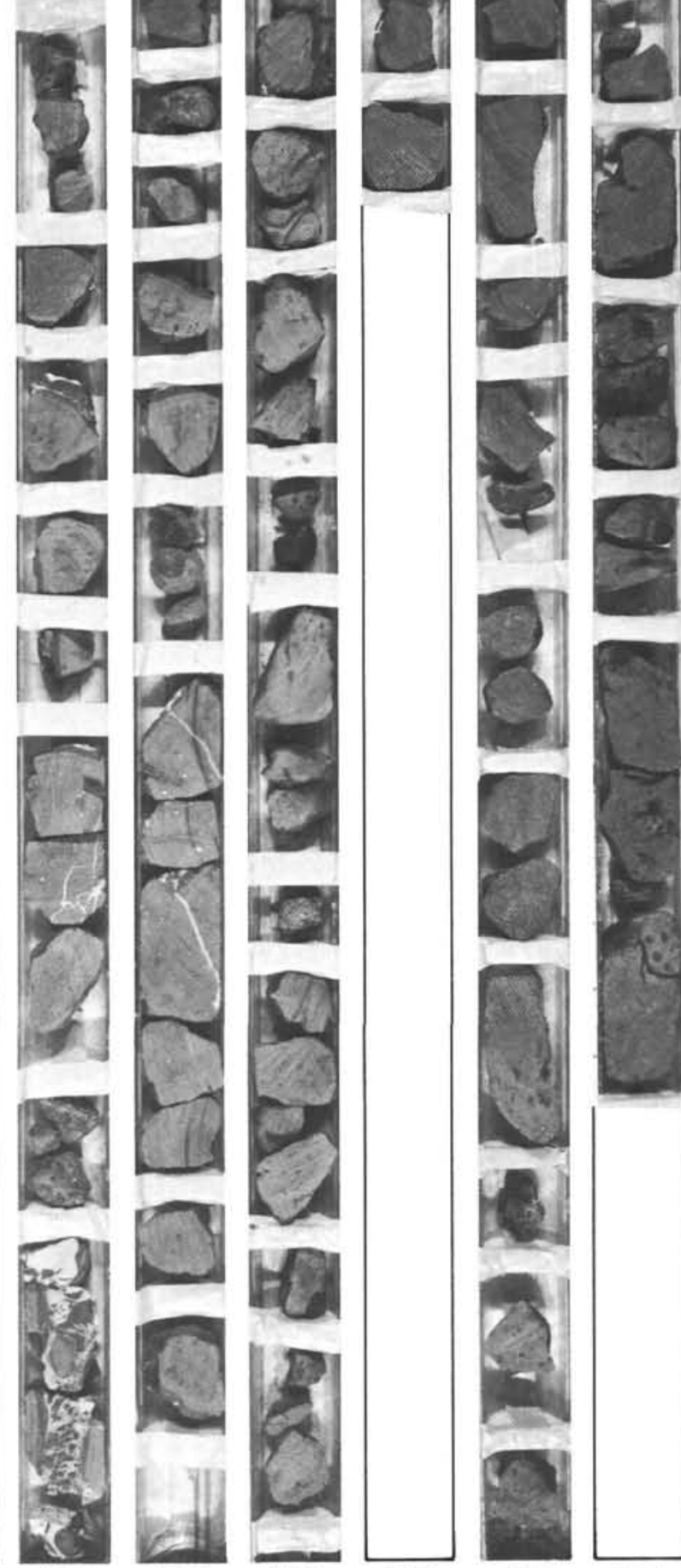

$15-1$

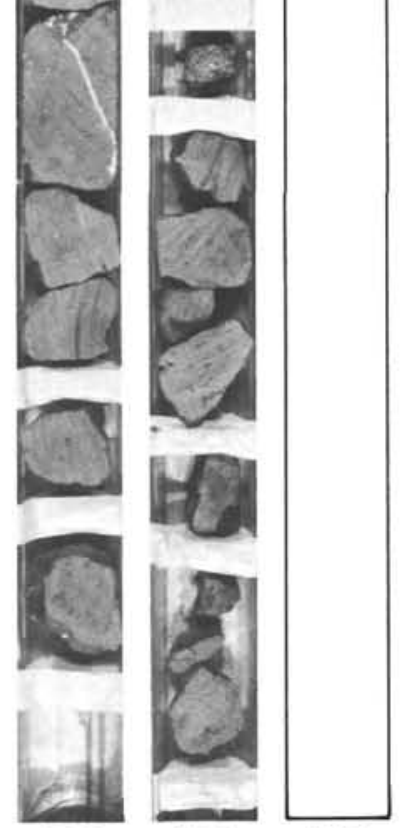

$15-2$

$16-1$
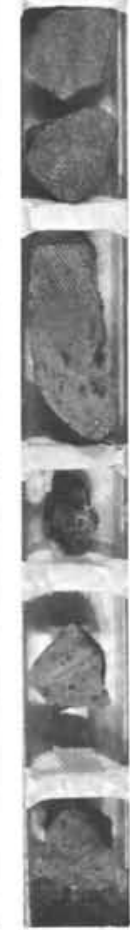

$17-1$

$17-2$
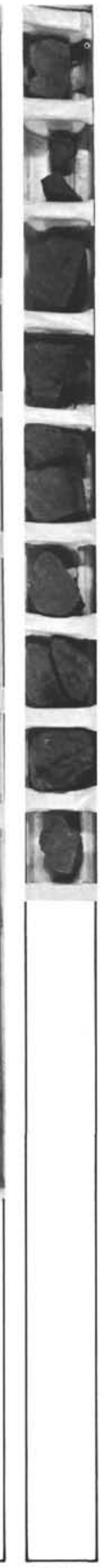